Florida International University FIU Digital Commons

9-30-1996

\title{
With the highest ideals: The Florida state normal college at Defuniak springs, 1887-1905
}

Sharon Y. Clifford

Florida International University

DOI: $10.25148 /$ etd.FI14060859

Follow this and additional works at: https://digitalcommons.fiu.edu/etd

Part of the Community College Leadership Commons

\section{Recommended Citation}

Clifford, Sharon Y., "With the highest ideals: The Florida state normal college at Defuniak springs, 1887-1905" (1996). FIU Electronic Theses and Dissertations. 2388.

https://digitalcommons.fiu.edu/etd/2388

This work is brought to you for free and open access by the University Graduate School at FIU Digital Commons. It has been accepted for inclusion in FIU Electronic Theses and Dissertations by an authorized administrator of FIU Digital Commons. For more information, please contact dcc@fiu.edu. 


\title{
FLORIDA INTERNATIONAL UNIVERSITY \\ Miami, Florida
}

\section{WITH THE HIGHEST IDEALS: THE FLORIDA STATE NORMAL COLLEGE AT DEFUNIAK SPRINGS, 1887-1905}

\begin{abstract}
A dissertation submitted in partial satisfaction of the requirements for the degree of
\end{abstract}

\author{
DOCTOR OF EDUCATION \\ IN \\ COMMUNITY COLLEGE TEACHING
}

by

Sharon Y. Clifford

1996 
To:

$\frac{\text { Dr. I. Ira Goldenberg }}{\text { College of Education }}$

This dissertation, written by Sharon $Y$. Clifford, and entitled With The Highest Ideals: The Florida state Normal College At DeFuniak Springs, 1887 - 1905, having been approved in respect to style and intellectual content, is referred to you for judgment.

We have read this dissertation and recommend that it be approved.

Jorge Meterson

PauYs. George

Jłseph B. Cook

Barry Grkenbefg, Major Professor

Date of Defense: September 30, 1996

The dissertation of Sharon Y. Clifford is approved.

Dean If Ira Goldbenberg

Collegle of Education

Dr. Richard L. Campdell

Dean of Graduate studies 
${ }^{\circ}$ COPYRIGHT 1996 by Sharon Clifford

All rights reserved 
This is dedicated to the women in my family who will have gone to college in three different centuries: my great-grandmother, Elma Erskine Miller, who graduated from college in 1888, my mother, Betty Miller Clifford, who graduated in 1945, and my daughter, Briana Katherine Baham, who will graduate in the year 2008 . 


\section{ACKNOWLEDGEMENTS}

Each of the members of my committee was unfailingly helpful and generous with their time and ideas. I appreciated their suggestions, every one of which improved this manuscript. My committee chair, Dr. Barry Greenberg, saw this through from start to finish. Dr. Paul George shared his encyclopedic knowledge of, and enthusiasm for, Florida history. I wish to especially thank Dr. Joyce Peterson for her support, insight, and time. At every stage in the writing of this manuscript, Dr. Peterson's careful reading and suggestions were invaluable. The interlibrary loan department went out of their way to assist me in locating materials that were often hard to find. The staff of the Special collections at the University of Florida were very helpful, as were the staff of the Florida state Library in Tallahassee and the Special Collections at the University of Miami. Dr. Samuel Proctor at the University of Florida and Dr. Robin Sellers at Florida State University were both very kind and willing to share their own extensive research on the early years of their respective institutions.

Mrs. Mary Virginia Cawthon Mock spent many 
hours searching through materials belonging to her aunt, Mary Lou Cawthon Turner, who attended the Normal College at the turn of the century. Mrs. Mock kindly shared these wonderful and rare items with me for this dissertation. Mrs. Jeanette Anderson MacDonald, whose father and uncle attended the school, contributed the photographs. Mrs. Winnie McEwen, who as a small child attended the model school run by Sallie Landrum Cawthon, contributed her own memories of the students of the normal school. Mrs. Virginia cate of the DeFuniak Springs Historical Society sent me material in the society's possession.

All of my family helped and supported me in every way possible. My husband read and edited this manuscript, and prepared the photographs. My most special thanks go to my mother and my daughter. Briana spent second, third, and fourth grades waiting up late for me to get home from school and never, ever, complained. My mother took loving care of Briana, early in the morning, at night, or on weekends. I could not have gone back to school without their support and help. My mother's memories of her grandmother, Elma Erskine Miller, one of the first generation of American women to go to college, fascinated me as a child, and inspired this dissertation. Without my mother, this would never have been written. 


\title{
ABSTRACT OF THE DISSERTATION
}

WITH THE HIGHEST IDEALS: THE FLORIDA STATE NORMAL COLLEGE AT DEFUNIAK SPRINGS, 1887 - 1905

\author{
by \\ Sharon Y. Clifford \\ Florida International University, 1996 \\ Professor Barry Greenberg, Major Professor
}

The urgent need for teachers led the Florida legislature in 1887 to establish the Florida State Normal College at DeFuniak springs. The college closed in 1905 with passage of the Buckman Act, which mandated a complete reorganization of state-supported higher education and ended coeducation for white students. This small college, open for eighteen years, was uniquely situated in time and place to examine larger questions in American educational history as well as contribute to the history of higher education in Florida, which developed differently than in other states.

This historical case study used archival sources to examine this institution, and contribute to the history of the origins of Florida's system of higher education. Key questions guiding the research were the nature of the students, fundamental aspects of school life, the impact 
of the school on the students, and the role of the school in the development of higher education in Florida. Original sources included the Catalogs, Register and Minutes of the school. The census of 1900 was used to develop information on the backgrounds of the students. Findings were: DeFuniak Springs was chosen for the school because of the Florida Chautauqua; the school was coeducational and had few rules but the internalized social codes of the students resulted in almost no difficulties with discipline; the students, a majority of whom were women, were from middle-class southern families; the college compared favorably in faculty, facilities and curriculum to institutions elsewhere; although few students graduated, alumni played a key role in shaping Florida's common schools; and, the Buckman Act entirely changed the nature of higher education in Florida.

Implications were: The coeducational nature of the college a hundred years ago significantly changes the picture of Florida's higher education; the school was small, but its influence far outlasted the institution; and, the school struggled with issues which continue to trouble modern educators such as finances, the legislature, student retention, underpreparedness, and the proper structuring of a curriculum, which indicates the persistence of these issues. 


\section{TABLE OF CONTENTS}

CHAPTER

PAGE

I. INTRODUCTION. .......................

II. LITERATURE REVIEW

Review of the literature..............6

Conceptual framework....................

III. METHODOLOGY

Sources and Methods..................62

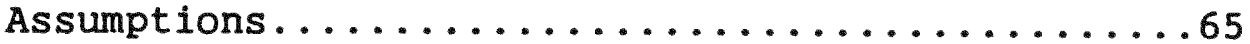

Limitations......................65

IV. RESULTS

The historical background..............66

Life in Florida....................67

Education in Florida.................... 73

DeFuniak springs and the Chautauqua.........84

The Florida State Normal School: Purpose and

Curriculum.......................94

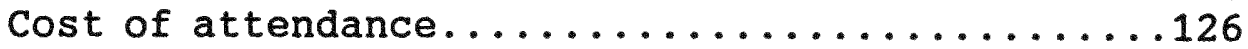

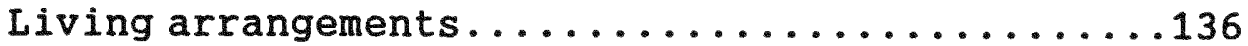

Life outside the classroom.............147

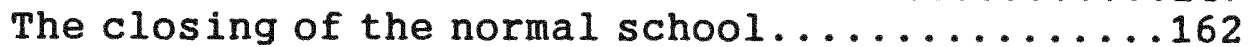

The faculty and students..............178

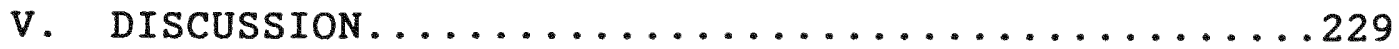

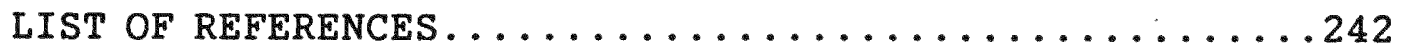

APPENDIX A

Graduates of the state Normal School........256

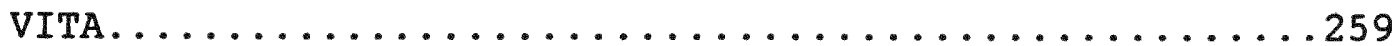




\section{LIST OF TABLES}

TABLE

PAGE

TABLE 1

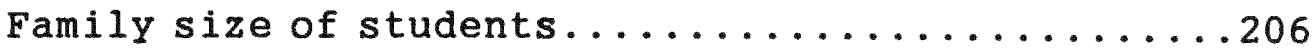
TABLE 2

Women students who were the oldest daughter.....207 TABLE 3

Students with siblings attending the school.....208 TABLE 4

Women students with siblings attending school....209 TABLE 5

Students whose father was 1 iving..................... TABLE 6

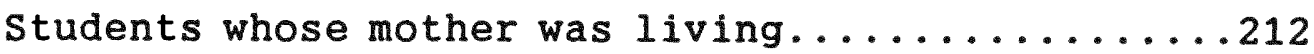
TABLE 7

Literacy among fathers of students...........213 TABLE 8

Literacy among mothers of students............214 TABLE 9

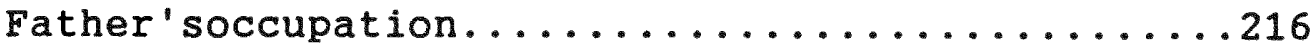
TABLE 10

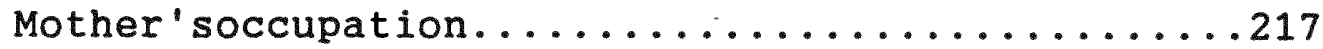
TABLE 11

Occupation of fathers of women students.........219 TABLE 12

Occupation of mothers of women students........220 TABLE 13

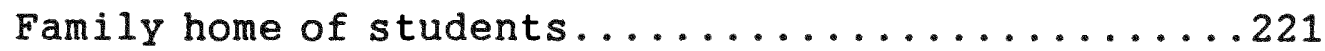
TABLE 14

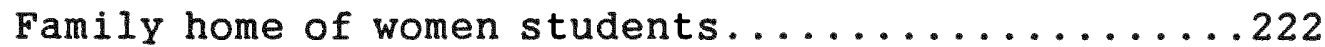
TABLE 15

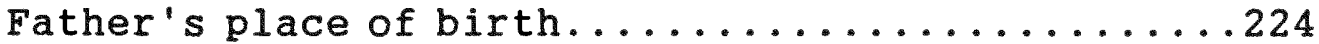
TABLE 16

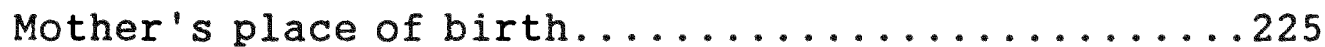
TABLE 17

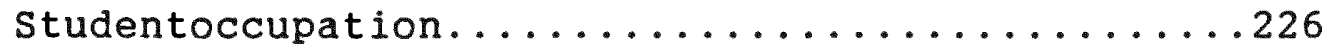
TABLE 18

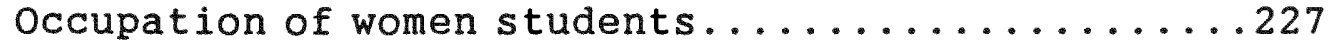




\section{LIST OF PHOTOGRAPHS}

\section{PHOTOGRAPHS}

PAGE

Classroombuildings....................... 125

Dormitory for young ladies.................. 146

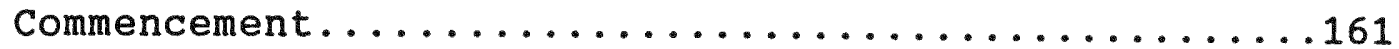




\section{Statement and significance of the problem}

The Florida State Normal College at DeFuniak Springs, a coeducational institution for white students, trained teachers from 1887 until the school closed in 1905. The years in which the school operated were significant for a number of reasons. The expansion of opportunities for women in higher education and in the teaching profession at the end of the nineteenth century could not have been foreseen even forty years earlier. Southern states, including Florida, had been devastated by the Civil War a generation earlier, and experienced these changes in ways particular to the region. The foundation for Florida's state supported educational system, from kindergarten through graduate school, was established during the period the school was open. In addition to filling in gaps in the history of Florida's system of higher education, study of the Florida state Normal College at DeFuniak Springs can be used to examine the progress of women and of education in the "New South."

During the $1880^{\prime}$ 's educators in the south began to challenge the overwhelming backwardness of southern education. Northern educators and philanthropists, wishing to assist in the long process of modernization 
and recovery, joined with them. What they found were one-room schools, many made of logs, in which teachers almost as ignorant as their students taught sessions lasting only a few months every year. The illiteracy rate among whites in some southern states actually rose after the end of the civil war. The educational situation of black southerners was even worse than that of whites.

The urgent need for teachers led Florida in 1887 to establish two normal colleges, the Florida state Normal College for White Students at DeFuniak Springs, and the Florida Technical and Normal College for Colored Students at Tallahassee, which today is Florida Agricultural and Mechanical University. Legislators selected the new town of DeFuniak springs rather than a more central location because of the influence of the powerful Louisville and Nashville Railroad. The railroad company had already persuaded the Florida Chautauqua to locate in DeFuniak Springs. Educators believed that the proximity of the Chautauqua would greatly benefit the students. The school occupied the Chautauqua building for two years before moving to its permanent location. Both of the normal schools were coeducational, as were other Florida educational institutions.

After eighteen years of operation, the normal school closed in 1905 when the Florida legislature passed the 
Buckman Act. This legislation, in the process of consolidating Florida's institutions of higher education, also ended coeducation for white students. The two new institutions established by the act, the Florida state College for Women at Tallahassee, and the University of Florida at Gainesville, remained single-sex institutions until after the end of the second World War.

The years in which the normal school at DeFuniak Springs operated were significant ones in the history of American education. Nationally, a broad movement for college education for women opened doors as women's colleges and state institutions educated the first generation of college women. Normal schools, which educated as many women as more prominent institutions, opened across the United States and provided access to education and a respected profession. The teaching force in the public schools became both feminized and professionalized at an amazing rate as young women took advantage of their new opportunities. The role of the common schools expanded enormously as Progressive Era reformers and educators realized that the schools were ideal vehicles for social improvement and reform.

These changes in American education and life were experienced in the South in ways particular to the region. The Civil War left the southern states, a generation later, poorer by far than even the poorest 
states in the rest of the country. Two races existed uneasily side-by-side and the "Jim Crow" era of segregation, extra-legal violence, and disfranchisement had begun. Massive illiteracy and poverty compounded serious public health problems. Hookworm was endemic, and a yellow fever epidemic in $1888 \mathrm{killed}$ thousands in Florida. Farm tenancy, widespread underdevelopment, and the desperate need for capital led to an economy based on the cultivation of cotton and the extraction of raw materials such as lumber and phosphate by Northern capitalists, who also controlled the railroads and banks.

The southern states all began extensive and often remarkable efforts in the $1880^{\prime} \mathrm{s}$ to educate their people. Northern educational reformers such as the Reverend A. D. Mayo, George Peabody, and even John D. Rockefeller, campaigned for educational and social reform in the South. While both southern and northern educational reformers emphasized education for whites, all of the southern states at least paid lip service to education for blacks, and recognized their obligation to provide some education for their black citizens.

The developments in American higher education, the education of women, teacher training, and the American common schools during the period in which the Florida State Normal College operated established the foundation for today's educational systems. Further, no educational 
institution exists apart from the larger society. Schools provide a unique prism through which to view culture, social change, and historical movements, reflecting as they do both reality and what society believes reality should be. The Florida state Normal College, open from 1887 to 1905 , is an ideal vehicle through which to examine all of these larger questions in American educational history. The normal school was small, and only open for a short period of time, but the school played a critical role in Florida's educational history. The study of the Normal School at De Funiak will add to our understanding of gender roles, education, and the development of Florida's system of higher education. 
Review of the Literature and Conceptual Framework

The study of the Florida state Normal College at DeFuniak springs encompasses a number of significant areas, which are interrelated and provide the essential conceptual framework for the dissertation. These were addressed in the survey of the literature, which included the role of women at the turn of the century in the United States, the entry of American women into higher education, the feminization and professionalization of the teaching profession, the role of the normal schools in American education, life in the "New South," and the crusade for education in the South.

The American Woman at the turn of the century

Although reformers challenged the position and expected behavior of women during the nineteenth century, it was not until the twentieth century that American women experienced any real changes in their lives. Prior to that, the contours of their lives remained remarkably constant. Most nineteenth century Americans assumed the existence of a world divided into male and female spheres by the laws of God and nature (Smith-Rosenberg, 1975, p. 9). Women lived in a world inhabited by children and other women and bounded by their homes, churches, and 
visits. They formed deep and lasting ties with their female relatives and friends (Smith-Rosenberg, p. 11). In 1900, as in 1800, women fed and clothed families, raised and taught their children, and cared for the ill and infirm. Despite labor-saving inventions, the week's wash took more than a full day of hard work, as did sewing, baking, and cleaning house. Frequent illnesses shortened life expectancies. Children were ten times more likely to be orphaned at the turn of the century than they are now.

The wives of factory workers sewed and took in boarders to supplement family incomes. Farm wives worked without stopping, often laboring in the fields as well as raising chickens, churning butter, cooking for hired hands, and doing the household work. Declining birth rates received an assist from women who controlled their pregnancies either through birth control measures or terminations, despite the laws instituted by crusaders against "race suicide" (Rosenberg p. 15-17).

"Virtuous womanhood," as it was understood in the nineteenth century, narrowly defined women's roles, which closed off opportunities and fostered the sexstereotyping of work. Women had to exhibit moral sensibility, purity, and maternal affection (Rothman, 1978, p. 14). In 1900, forty percent of all unmarried women over the age of fourteen worked for wages, but 
women entering the labor force had very limited options. (Rosenberg, 1992, p. 19). New jobs opened as industrial capitalism changed the economy, but these rapidly became sex-stereotyped. Women worked as typists, stenographers, and department store clerks, with no possibility for advancement. The first job a woman took was usually the job she kept (Rothman, p. 42).

However, American life was about to change. The $1890 \mathrm{~s}$ marked the ascendance in the United States of urban, industrial lifeways over traditional small communities and farms as the defining characteristic of American society (Evans, p. 147). American women shaped immense social changes between 1890 and 1920 with their participation in voluntary associations, institutions, and collective social movements (Evans, p. 145). The emergence of the college-educated woman led to a new ideal of womanhood, which transformed the public and private duties of women, and altered both the tasks of mothers and the obligations of the state. This new ideal, labelled "educated motherhood," redefined the role of women and rationalized the higher education of women (Rothman, p. 97, 106). "Educated motherhood" required the leadership of the college women, who participated in shaping and implementing progressive social reform policies (Rothman, p. 108).

Women college graduates confronted the problems that 
industrialization, urbanization, and immigration had created and attacked them with exuberance (Rothman, p. 111). The settlement house movement was the concrete symbol of the confidence of the new college women that their maternal abilities and intellectual training could school the young, train and acculturate the immigrant, and improve the health of women and children.

The college women led a revived suffrage movement. Suffragists used the arguments of female reformers that the state needed women for their ability to contend with the problems of hunger, poor sanitation, and education (Evans, p. 153). Suffragists and college women argued that female morality could clean up corruption and that women needed the vote in order to protect the special interests of women and families (Evans, p. 154). This did not violate the doctrine of separate spheres, for suffragists made it clear that they only wished to extend their influence into areas that traditionally belonged to women. A powerful coalition of suffragists, child welfare reformers, middle-class club women (of whom there were 150,000 in 1900), and working girls fought for suffrage and for greater protection of women and children (Rothman, p. 131, Evans p. 150).

After 1900, strict segregation of the sexes eroded, which alarmed many observers. Sociologists editorialized in print on the imperiled American home as early as 1904 
(McGovern, p. 319). Young working-class women in the cities dressed flamboyantly after work and went to dance halls. In 1900, proper young women still emulated the Gibson Girl look, but ten years later they wore cosmetics, had shortened their skirts, and were performing modest versions of the "rags" popularized in the working-class dance halls.

Whether a college-educated "New Woman" or a "working-girl," women's individualization had begun (McGovern, p. 320). Scientific thought, bureaucratic organization, and professionalization all played a part in liberating the American woman in the first decade of the twentieth century. This individualization and modernization brought women both gains and losses as the female community that had given American women comfort and strength eroded (Evans, p. 173).

\section{The Education of Women}

The previously unimaginable entrance of tens of thousands of women into institutions of higher education was a revolutionary change. Access to higher education had a profound impact on women and on American life and culture.

During the colonial period women were educated, if at all, in select dame schools and academies. Even in New England, women learned only enough to read Scripture 
and keep household accounts. More education for a woman was considered superfluous.

A new conception of womanhood emerged during the American Revolution and the early national period. "Republican motherhood" integrated the domestic relationships of women with the ideology of the new republican nation (Schwager, p. 337). American women still could not vote or hold property apart from their husbands, but as the mothers of sons who would participate in national affairs, women assumed an important role in American ideology. The new nation lacked Europe's traditional hierarchies and American Protestantism emphasized the primacy of the individual. In the absence of a hierarchical structure, the internal restraints instilled in the sons of the Republic by their mothers meant social stability and order (Bunkle, p. 17). If American women were to properly bring up and educate their sons, they needed to be educated. Major improvements in women's education took place during the Republican period between 1790 and 1830, and female literacy rates rose dramatically (Schwager, p. 339).

Emma Willard, a believer in the ideology of Republican motherhood, founded the Troy Seminary in New York in 1821. Reasoning that the future prosperity of the Republic depended upon the character of its citizens, and that only educated mothers could form characters of 
the necessary quality, she used popular ideology to gain support for her seminary. Mrs. Willard reasoned that as educated citizens were essential to American republicanism, women must be trained to teach the multitudes of young Americans (Scott, 1979, p. 6). Over the next fifty years, more than 12,000 women studied at Troy, the first female institution comparable to a men's college (Scott, p. 5).

Catherine Beecher, whose Hartford Seminary opened in Connecticut in 1828, also maintained absolute social correctness while advancing the education of women, reasoning that the instruction of American children extended motherhood into the public sphere and served the Republic. Despite this cautious approach to women's education, the young women who entered the seminaries were affected by the friendship, sisterhood, and support they experienced. In each generation after 1820, a larger number of women enrolled, first in seminaries, and then in normal schools and colleges, and each generation had more independent women in it than the one before it $($ Scott, p. 20).

As the young nation expanded and industrialized between 1830 and 1870 , a new conception of womanhood, known as the doctrine of "separate spheres," was popularized in the North. This ideology of gender, which is usually explained by the modernizing and expansion of 
the economy, dominated the perceptions of nineteenth century women. Men were drawn to new economic opportunities, and goods formerly produced at home could now be bought in the marketplace. Women lost their economic function within the family, and instead assumed "supreme domestic powers." Women were powerless in the world of temporal affairs, but the doctrine of separate spheres assured them that they had a much greater power, as the agents of Christian salvation responsible for the eternal souls of their children. Pious expressions and sentimental depictions of the home and Christian motherhood dominated the imagery of the times. The most accomplished women of the era claimed to adhere to their prescribed roles. Harriet Beecher stowe took no credit for her accomplishments, saying that she wrote as the instrument of a higher power. Sara Josepha Hale, the editor of the most important woman's magazine of the century, Godey's Lady's Book, said that she worked only in order to help to usher in the millenium (Bunkle, p. 22). American women never perfectly fulfilled the stereotype but it was impossible for them to ignore its dictates (Kelley, p. 89).

New types of institutions opened for women during the 1830s. The first normal school opened in 1830 , as did the first woman's college, Georgia Female College in Macon. Mary Lyon opened Mount Holyoke as a seminary in 
1836. In 1837, Oberlin admitted four women as students, becoming the first coeducational college in the United States. These institutions did not threaten contemporary values. The motto of Mt. Holyoke was "study and teach nothing that can not be made to help in the great work of converting the world to Christ" (Bunkle, p. 21). The seminaries, and oberlin, trained women to marry, to teach, or to spread the Gospel. Frontier ministers were trained at oberlin, and the school educated young women to be fitting marriage partners for these men. At Oberlin, the male students raised crops on the school farm, while the young women cooked, served, and waited on tables. No classes were held on Mondays so that the women could wash and mend clothes for the men students. The women did their own laundry in the evenings (Conway, 1974, p. 6).

The University of Iowa admitted women in 1855. By the time of the Civil War, eight state universities in the Midwest and West accepted women and a number of institutions began to offer a small number of women at least the beginnings of a college education (Newcomer, p. 13-14). The expansion of the common schools, the urgent need for teachers, and a growing number of women working outside their homes during the years before marriage were all factors in the growth of women's education before 1870 . 
Between 1870 and 1910, American women found many new opportunities. The 1870 census listed, for the first time, every occupation in the United States, and found at least one woman in each of the 338 occupational categories. Two million women worked for pay in 1870 . Seven occupations (domestic service, agricultural labor, seamstress, milliner, teacher, textile mill worker, and laundress, in that order) accounted for 93 percent of employed women (Newcomer, p. 17). Women took advantage of any opportunity given to them to receive more education. Families attempted to plan for their daughters's futures by providing them with an education (Allmendinger, p. 36). In the words of a ninenteenth century Kansan, "the hardships of farm life caused parents to plot professional life for their brighter children. Many a youth, boy and girl, went through college in the $1890 \mathrm{~s}$ and the early 1900s partly to escape... farm life" (Clifford, 1978, p. 12). A mother's support for a daughter seeking an education often related to her own difficult life. Rural mothers who saw education as a way out of the constrictions, isolation, and poverty of rural life, were among the first to seek higher education for their girls (Solomon, p. 68).

As state institutions in the Midwest and West cautiously opened their doors to women, several women's colleges in the Northeast were founded, beginning with 
Vassar in 1860. Wellesley and Smith opened in 1875, Bryn Mawr in 1888, and Racliffe in 1893. Between 1870 and 1900, the number of women enrolled in institutions of higher learning in the United states multiplied from 11,000 to 85,000 (Solomon, p. 58). Of the 11,000 women enrolled in 1870, a majority studied in institutions which did not award the bachelor's degree. Five thousand women were enrolled in normal schools and another three thousand in seminaries (Newcomer, p. 19). In 1900, fifty thousand of the women enrolled were preparing to teach, forty-five thousand of them in normal schools (Newcomer, p. 89). In 1870, women were 21 percent of the total enrollment in institutions of higher learning in the United States. By 1910, women were nearly forty percent (Graham, 1978, p. 764). During these years, a heterogenous array of "acceptable and praiseworthy" institutions educated American students (Graham, p. 761).

The number of students unprepared for college course work created difficulties for all the higher educational institutions. The lack of high schools, low standards of admission, and the fluid nature of the American educational system meant that students arrived at the doors of colleges, normal schools, and universities who were unprepared, but had to be accomodated. During Wellesley's first year, only thirty of three hundred and fourteen students were qualified for college work. In 
1870, one hundred and fourteen of one hundred and forty institutions had preparatory departments (Newcomer, p. 21). In 1890, there were nearly as many preparatory students as regular students enrolled in higher education (Newcomer, p. 22). The difficulty of combining two programs while maintaining the integrity of the college program was compounded in the case of women by the critics who charged that women were mentally inferior to men and incapable of completing post-secondary studies (Newcomer, p. 22, 26).

Other issues complicated the task of educating women. The women who sought a higher education in the nineteenth century received a great deal of attention from journalists, educators, and the public, which caused problems for the women and the schools. Americans were curious about these young women, and about the effect higher education had on them. Would these women become unfeminine and man-like? (Frankfort, p. xv). Many Americans thought educating women to be unnatural (Wein, p. 31). Many more believed that society would receive little benefit from educating women (Solomon, p. 61). In 1875, Dr. Edward Clarke, of Harvard University, launched a devastating attack on women's higher education with a best-selling book, Sex in Education. Clarke claimed to oppose the higher education of women for reasons of health. He argued that the strain of mental 
exertion in women would destroy their health and have disastrous effects on the reproductive systems of young women. Young women who over-studied risked sterility, frigidity, and hysteria. They would not marry or be able to bear children. Clarke's attack was taken seriously by the institutions and by women students themselves, forcing them to devote an inordinate amount of effort to promoting health among students and to disproving Clarke's contentions.

As time went by, and women students stayed as healthy as any other group, new fears of "feminization" and "race suicide" dominated the debate over women's education. The worry that women would lose their femininity was replaced by arguments that men in institutions of higher learning were losing their masculinity. Articles in popular journals discussed the dangers of the "woman peril" in the common schools and universities. University professors and administrators in coeducational institutions claimed that the women students had driven men out of the liberal arts and in fact discouraged the "best" men from attending college at all (Rosenberg, p. 45). While critics no longer questioned the mental capacity of women students, they objected to women's academic achievements, especially when women surpassed men in academic honors (Solomon, p. 58). Institutions responded by implementing gender 
segregated courses of study designed specifically for women, such as domestic science (Rosenberg, p. 51). Life outside the classroom in the coeducational colleges was rigidly segregated by sex (Zimmerman, 168).

The publication in 1904 of Adolescence, by G. Stanley Hall, coincided with the outcry against feminization. The book started a debate over "race suicide" that filled the pages of journals between 1905 and 1910 (Coburn, p. 20). Women suffering from "overbrain work" would be functionally castrated, abhor married life, and harbor phobias about childbirth (Frankfort, p. 88). The low marriage rates and small number of children of the first generation of women college students were used to prove that the Anglo-Saxon race in the United States was in grave danger of being overrun by new immigrant groups with high fertility rates.

While the number of institutions open to women continued to grow, as did enrollments, the attacks on women's higher education forced both students and institutions into ambivalent posisitons. Colleges and universities vacillated between claiming that they prepared women to take up professional lives and claiming that they prepared women to be better wives and mothers (Bunkle, p. 27). Members of the Association of Collegiate Alumnae, founded by Marion Talbot and her 
mother in 1881, showed the same ambivalence. The association worked to dispel Clarke's accusations, to expand opportunities for women in higher education, and to monitor the condition of women in the colleges and universities. Still, members affirmed their belief in the sanctity of home and family and suggested that college women who did not wish to enter teaching instead train for "suitable" part-time occupations in fields such as child psychology, domestic and library science, and social work (Wein, p. 33). Alice Freeman Palmer, the first president of Wellesley College and the Dean of Women at the University of Chicago, exemplified this dilemna. As president of Wellesley she argued that she was educating women, not for work as professionals, but for the cultivation of domestic life. After much hesitation, she herself had to resign her position when she married a Harvard professor. Women's colleges emphasized the "polish" their graduates acquired, and the colleges undoubtedly served to introduce young women to eligible men.

These conflicts and ambivalencies were rooted in American culture. The proper role for women in a country founded on an ideology of republicanism and Protestantism has been contradictory and controversial since the early days of the Republic, and was especially confused in the industrial economy at the end of the nineteenth century. 
On the one hand, women continued to be wives, mothers and housekeepers. On the other, progressive reformers, horrified at the excess and ruthlessness of American business culture, believed that women's nurturing qualities should be professionalized and extended to the larger society (Conway, 1985, p. 89). An uneasy compromise resulted, which lasted far into the twentieth century. Women could be educated, but their educations formalized the roles women already held. By 1910, American collegiate women studied for the careers they would dominate throughout this century: teaching, domestic science, and social work (Rury, p. 85).

Still, between 1870 and 1910, an extraordinary change in American education had occurred. Whatever the hardships, and the limitations of their opportunities, women as a group had entered American higher education, shaping it and themselves (Solomon, p. 61). Great changes in the deeply-held values of our society have rarely occurred as sudden breaks with the past. If the thought and behavior of the new college-educated women of the late nineteenth and early twentieth century was paradoxical, it was the ambivalence which is common to any group when long-held values are in the process of changing (Scott, 1979, p.4).

Changes in the teaching profession 
At the end of the nineteenth century, teaching had been transformed from a part-time, short-term "job" for men into a "profession" for women (Hoffman, xviii). Women had taught for centuries in the home, in convents, and in dame schools, but it was not until the latter part of the nineteenth century that women as teachers moved into the public sphere, teaching in huge numbers in the American public schools. The numbers tell the story of this starting transformation in the teaching force and in the lives of American women. In 1870, 25 percent of teachers were women. In 1900, the number of women teachers had risen to two thirds of the teaching force, and in 1920 to 86 percent. The number of women teachers tripled between 1870 and 1900 (Richardson, p. 90). While historians dispute whether men left teaching because women entered it, or women entered it because men already were leaving, the transformation was indisputable. The acceptance by Americans of women as teachers startled European educators and differentiated the American educational system from all others (Clifford, 1988, p. $167)$.

This transformation occurred as a number of significant social and cultural changes impacted the American public schools. Urbanization and industrialization changed the nature of work in late nineteenth century America. More and more American men 
engaged in nonagricultural labor. The new occupations and opportunities of an expanding industrial nation required substantially more education than the formerly agricultural labor force had needed.

Millions of immigrants entered the United States between 1880 and 1930. The vast numbers of non-English speaking immigrants from the nations of central Europe created inevitable pressures on the educational system. Reformers and government officials viewed the schools as the best vehicle for assisting in the assimilation of the immigrant children, and through them, their parents, into American society.

Other demographic changes affected the teaching force. American families had grown smaller. The average family size of seven children in 1800 decreased to 3.9 children in 1900 (Clifford, 1982, p. 230). Fewer middleclass families took in boarders. With fewer family responsibilities, daughters had more freedom to continue their schooling and to seek paid employment for the years between school and marriage. The migration within the United states of young men leaving the East to seek their fortunes in less developed regions of the country, created numbers of "superfluous women" between 1870 and the 1890 's. These young women who might never expect to marry needed an education and a respectable way in which to earn a living. 
The mechanizing of the farm affected the daughters of farmers in every part of the country. More machinery meant fewer farm hands and fewer responsibilities for young women, who helped cook for the hands as well as doing their share of farm work. Now the daughters of farmers, as well as town girls, had more freedom to study and to prepare for careers (Clifford, 1989, p. 303). The states, one by one, enacted compulsory schooling laws. These laws, the flow of immigration, and the large number of young women going to school created an insatiable demand for teachers, and young women were quick to enter this new profession. The enactment of compulsory schooling laws signified the assumption by the states of the responsibility for educating their citizens. As county and state school boards created formalized and expanded school systems, the need to economize made women very attractive as teachers (Richardson, p. 83-84). Women teachers were paid much less than men. The lower salaries paid to women, justified on the grounds that women only taught for an average of four years before leaving to marry (an argument which ignored the fact that most school systems required married women to leave), subsidized both longer school terms and more classrooms (Hoffman, xiv). Women's low wages also made the expansion of high schools a possibility, thus paying for education for the children 
of the middle classes as well as for the masses educated in the common schools (Clifford, 1988, p. 299). At a time when the nation's population of school children doubled, the ratio of students to teachersu fell dramatically with the entry of women into the nation's classrooms.

Predictably, there was a backlash in reaction to the newly feminine teaching force. In 1875, Charles Eliot, president of Harvard, led the attack, arguing that the hiring of women as teachers was an "unwise economy" (Eliot, p. 220). Distinguished male professors in the universities and administrators in the public schools felt threatened by women as students in American colleges and by women in the classroom as teachers (Clifford, 1989, p. 326). Famous educators worried about the lack of manly role models in the schools, and argued that women were incapable of properly training male children. Educators feared that the young American male was in danger of becoming timid, weak, and unmanly (Woman Peril, p. 115-116, Schindler, p. 63). Critics also argued that teaching was too arduous for women, and that the existence of so many unmarried employed women threatened to destroy American homes (Too Many Women, p. 101). Hostile attacks in the pages of the periodicals of the day did not keep women out of teaching, but they did prevent women from advancing into administrative and 
policy-making positions, where women held only a miniscule number of jobs (Clifford, 1989, p. 326, Cordier, p. 36). Women were capable of teaching children the $A B C$ 's and the virtues of cleanliness, tidiness, obedience, and respect, but men were assigned to teach about ideas and organize the profession (Hoffman, xxii). A two-tiered educational structure was established, in which large numbers of young female teachers were supervised and controlled by older male administrators (Rury, 1989, p. 28). Typically, unless a woman moved to a different school, the teaching job she first took was the job she stayed in for the rest of her career (Rothman, p. 47).

Had teaching indeed become "repellent" to men, as a 1908 article argued? (Bardeen, p. 351). The number of men who taught fell from 55 percent of all teachers in 1880 to 16 percent in 1920 (Rury, 1989, p. 28). Changes in the nature of teaching itself caused men to seek other work.

In earlier times, the short school term allowed men to teach while continuing to farm, preach, run a business, or study law (Clifford, 1989, p. 310, Rury, 1989, p. 14). The new, longer school terms no longer permitted such dual careers. Further, the formalization of state school systems and subsequent demands by school boards for increased competence in the classroom raised the minimum 
age for teachers and required teachers to spend more time training and in continuing education, usually during the summers, which many men were reluctant to do. The expanding industrial economy offered young men opportunities for which they did not have to prepare as much. In economic terms, the "opportunity costs" associated with teaching had risen higher than young men were willing to pay (Clifford, 1989, p. 310). Men would have probably looked for other employment even if the profession had not become so "feminized."

If men saw teaching as an undesirable profession, the hundreds of thousands of young women who entered teaching between 1880 and 1910 decidedly did not. Teaching undeniably appealed to women. The profession offered studious young women an eminently respectable and acceptable occupation (Hoffman, xix). Middle-class families were pleased to educate their daughters for a profession which they believed could help to protect them from life's uncertainties (Rury, 1989, p. 9-10). Teaching was seen as a natural extension of woman's maternal role. Sentimental views of teaching became educational dogma as the views of Friedrich Froebel, who believed that the ideal teacher of young children was like a "mother made conscious," were popularized (Steedman, p. 149). The widely held idea that teaching prepared young women for their true vocation as wives and 
mothers has remained current at the end of the twentieth century (Clifford, 1982, p. 234).

While women teachers were paid the same as a "hired girl" who received room and board, the respectability of teaching was an undeniable lure (Cordier, p. 19). Teachers were admired, and, like social workers and home economists, they were women who had become educated and worked, yet were seen as acceptable by society (Clifford, 1989, p. 313).

Other factors made teaching appealing as well. Women recorded in their diaries that they desired incomes and independence. Popular periodicals glorified the teacher as mother, but teachers themselves found the continuity between teaching and motherhood was far less significant than a paycheck and the opportunity to work (Hoffman, xviii). Despite the prevalence of rules prohibiting married women from teaching, local school districts, which did the actual hiring, were often pleased to hire married women with teaching experience who had decided to return to the classroom. Many women did so. Schools at the end of the nineteenth century were often primitive and the work was hard, but women who taught enjoyed prestige in their communities, their paychecks, and the flexibility offered by teaching careers. The summer institutes so dreaded by male teachers were often looked forward to with anticipation 
by the women, who made friends and enjoyed the break from their daily lives (Cordier, p. 54-57). As teachers, women had a salable skill which allowed them to move from job to job seeking higher salaries, better working conditions, or even improved opportunities to meet potential marriage partners (Clifford, 1989, p. 324). The involvement of women teachers in community and educational advancement, the esteem in which local communities held many of their teachers, and the opportunity for some independence and financial security attracted hundreds of thousands of women around the country to the teaching profession.

The Professionalization of Education

As the states undertook responsibility for educating their citizens, demand slowly grew for a more professional teaching force. Still, as late as 1910 fewer than two thirds of American public school teachers had a high school education and only five percent had more than that (Clifford, Man Woman Teacher p. 309). For many beginning teachers, an eighth grade education and the willingness to try were enough to qualify for classroom teaching. As much as Americans desired educations for their children, the idea of educating teachers for teaching impressed the public as a waste of time and educational resources. 
When states assumed responsibility for education they began to examine teachers and to standardize the process for obtaining teaching certificates. In most states, teachers could start with a "Class D" certificate, which allowed them a year in the classroom before beginning the process of earning higher certificates. The highest were "Class A" and "Life" certificates. Many teachers, especially in rural areas, found it difficult or impossible to leave their positions to attend a normal school or college, so the states developed ongoing education planned specifically for teachers (Cordier, p. 45).

The teacher examinations measured knowledge of the subjects that the candidate would be expected to teach. While questions in school management and teaching methods were included, the exams primarily consisted of recall questions and essays to test the teacher's competence in subjects such as mathematics, English, history, American government, geography, and handwriting (Cordier, 52).

In order to prepare for the certificate exams, country teachers attended county and state teacher's institutes well into the twentieth century. The first institute was held in New York in 1843. By 1850, most northern states held institutes and states in the South and the West began to show interest in the idea (Judd, p. 25). Early teacher institutes were one day county 
conventions which served as educational revivals, giving teachers the opportunity to exchange ideas and form friendships (Judd, p. 25).

In 1874, the first Chautauqua was held at Fair Point, New York, to train Sunday school teachers. In 1879, the training for teachers expanded to a "Teacher's Retreat" and became an integral part of the Chautauqua movement (Avent, p. 13). While few teachers could afford to travel to the Chautauqua teacher's retreats, county and state institutes took up many of the chautauqua programs and expanded the teacher institutes to "summer normal teacher institutes" which lasted from two to six weeks. Sequenced instruction allowed teachers to progress from year to year, and accomodated all levels of students and certificates. The majority of nineteenth century teachers were in fact educated and certified by institutes (Cordier p. 60, Judd p. 26). Participants paid fees averaging a dollar a week. They boarded with other teachers at very economical rates, so the institutes were affordable even for country teachers.

A typical institute program featured sequenced content classes in the mornings. Students prepared assignments and recited their lessons, improving their knowledge as well as learning methods of instruction (Judd, p. 25). In the afternoons, the teachers attended inspirational speeches, observed demonstrations, or heard lectures on 
topics such as educational theory, hygiene, discipline, and school architecture. The evenings featured special lectures by invited guest speakers. Most days did not end until eight or nine in the evening (Smart, p. 171187). At the end of the summer normal institute, aspiring teachers could take the exam for their next certificate, exchange addresses with new friends, and then return home with a renewed zest for teaching. By 1900, some universities offered to hold summer training courses. The famous Peabody summer session, first held in 1902, trained thousands of southern teachers. The six week sessions were free, and the railroads offered a uniform low fare to teachers from any point in the south.

During the school year, rural teachers who wanted to continue their studies participated in reading circles sponsored by the education departments in their states. Members of the reading circles were assigned texts to read and then were tested. Although the National Education Association and state superintendents urged rural teachers to participate in the circles, teachers responsible for the operation of country schools had little time for extra reading and preferred to continue their schooling at the institutes.

The Normal Schools

The first suggestion of record that Americans needed 
special institutions for the purpose of training teachers appeared in an article in Massachusetts Magazine in 1789 (Gordy, p. 9). During the early years of the Republic, most Americans disliked the idea of training individuals at public expense for a profession assumed to require no special professional knowledge. Advocates of such training argued the need for it for decades (Ellsbree, p. 145). American teachers bought thousands of copies of Samuel R. Hall's 1829 "Lectures on School-Keeping," but it was not until travelers to Europe published reports on Prussian teacher training that American normal schools received public support. In the $1830^{\prime} \mathrm{s}$ these accounts were read with great interest by educator Horace Mann of Massachusetts and others like him (Rothman, p. 56).

In 1838, the Massachusetts legislature approved the opening of normal schools to train rural school teachers. The first opened with three students in 1839, with Cyrus Peirce as principal (Ellsbree, p. 146). Peirce told his wife that he would rather die than fail, and destroyed his health keeping the school going. For three years, until he collapsed, he worked as his own janitor, sleeping three hours at a time so he could wake to fill the furnace. He shovelled snow and brought in water before preparing lessons for a long day of school (Gordy, p. 51).

Peirce developed a normal school program with four 
components. First, students received a careful review of what they would be teaching in the schools. These were usually reading, writing, orthography, geography, and arithmetic. Second, they received instruction in the art of teaching. Third, they studied school management with the object of instilling moral behavior in the students. Fourth, normal school students used a common school as a school of practice (Gordy, p. 44-45). The normal school movement throughout the century adhered closely to Peirce's original vision. American normal schools agreed that the preparation of teachers consisted of two important tasks: the mastery of the material to be taught and the mastery of the history, philosophy, science and methods of teaching practice (Gordy, p. 129).

Although the stated purpose of the normal schools was that of preparing teachers to work in rural schools, the public viewed the first normal schools as adaptations of American secondary schools, and the schools resembled American academies much more than they did the Prussian training schools which had inspired them (Ellsbree, p. 144).

The normal school idea spread in the northern and midwestern states. By 1865, there were a total of eighteen state supported or sponsored normal schools in the United States, none of which were in the South. The Union Institute, which opened in North Carolina in 1853, 
had closed by 1859 (Ellsbree, p. 152). After the Civil War, the number of American normal schools grew quickly. By 1890, there were ninety-two, and most of the southern states had opened at least one normal school. In 1909, one hundred and forty two publicly supported normal schools operated in the United States. The number of students grew in similar fashion.

Normal schools expanded in scope as well as in number. As the American system of education became more formalized, normal schools differentiated their curriculum. The early normal schools offered one year courses. By 1870, many offered two, three, or four year courses. Although entrance requirements varied wildly and thousands of students (many of whom were already teaching) matriculated with a common school education, by 1900 slightly over a fourth of the entering students had high school diplomas. Most schools found it necessary to offer preparatory work to students with less education before allowing them to begin the regular normal school course (Harper, p. 105). The programs offered reflected the changing nature of the schools for which teachers were trained. Normal schools originally trained teachers for rural elementary schools, but the expansion of high schools and of bureaucratized school systems created programs to train secondary teachers and school administrators (Herbst, p. 222). 
The normal schools based their curriculum on the components first outlined by Peirce. As the schools grew, they offered electives and extra-curricular activities which could be useful to teachers, such as debate and drama clubs, literary societies, and athletic associations (Ogren, p. 3, Harper, p. 119). Enthusiasts of the manual training movement of the late 1800's added this to the curriculum as well, for both men and women students .

Normal school students popularized the educational theories of the nineteenth century, such as "object teaching" and the "Herbartian method." These theories reached schools in every part of the country, spread by normal school students. "Object teaching," known as the "Oswego method," was characterized by bringing real materials into the classroom, teaching through actual experience, and the manipulation of objects. Normalites took the method everywhere in the United States between 1860 and 1880 (Harper, p. 122).

Illinois Normal University introduced a second theory in 1886 which had the impact of a "tidal wave" on American educational practice (Harper, p. 124). The "Herbartian movement" introduced American teachers to Froebel's concepts of apperception, the culture epoch theory, and the "doctrine of interest," which argued that students learned best when their interest in a subject 
was first stimulated by the teacher. This movement, spread by the normal schools, influenced John Dewey and other prominent educators, who belonged to the American Herbartian Society.

As new theories changed established teaching practice, the model schools where teachers trained began to be used as laboratories for the purpose of introducing and evaluating these new concepts of education, giving the training of American elementary school teachers a theoretical and scientific aspect which is still retained in modern universities (Herbst, p. 226).

Normal schools enrolled women in large numbers, which contributed to the low esteem in which the faculty and students of colleges and universities held the normal schools (Clifford, 1983, p. 25). The ratio of female to male students varied from 14 to 1 to 1.3 to 1 in the Oklahoma Normal in 1900. Attendance at normal schools grew from 10,000 students nationwide in 1870, which was 16 percent of the total enrolled in some form of higher education, to 76,000 , or 30 percent of total higher education enrollments, in 1900 (Ogren, p. 2)

Normal schools had a great impact on the course of American education at all levels. The American normal schools were established to train elementary teachers, especially for rural schools. However, many students used the schools as one of the few available 
opportunities to receive an advanced, publicly supported education in the nineteenth century. Many normalites may have been more interested in receiving some form of higher education than they were in teaching in the primitive rural schools. The normal schools in the West and the south called themselves "colleges" from the beginning, and insisted on long curriculums with general education components (Harper, p. 109, 131). University faculties considered the normal schools little more than secondary schools, but it was the normal schools rather than state universities which extended higher education to the people, especially in the rural areas of the country. Normal schools trained teachers for the country schools, and also functioned as academic centers for young people regardless of their later occupations. The American normal schools set students on the road to upward social mobility rather than placing them for long in the role of country teacher (Herbst, p. 219). Eugene Branson, the president of the Georgia state Normal School at Athens, said the school's students "come heart-sick and heart-hungry for something more than they know and something better than they are" and struggled "with the desperation of drowning men and women" for their educations (Branson, p. 1890-1891).

Although critics accused normal school graduates of receiving a general education at state expense, the 
schools and their graduates transformed teaching into a profession (Harper, p. 111). Normal school faculties published an impressive amount of professional literature on American education. Emphasis on the use of model schools for training of teachers and as laboratories for research on pedagogy changed American educational practice. Normal schools developed teacher training as a field of study long before universities showed any interest in common school teachers. Normal school faculties had a near monopoly on the teacher institutes, reading circles, and summer sessions that trained most American teachers in the nineteenth century. The demand for normal school trained teachers was so great that only seven percent of the students who enrolled each year stayed to graduate. Those who dropped out did so primarily because they had been offered jobs after completing the first year of normal studies (Harper, p. 122). The number of normal-trained teachers in the United States was actually much higher than the number of graduates indicates.

Normal schools offered their students coeducational environments, very different from the academic and social environments at the "coeducational" universities of the time. Men and women students followed the same course of study, had professors of both sexes, and participated together in extra-curricular activities such as drama, 
debate and literary societies (Ogren, 3). Gender stigmatization was much less apparent at the normal schools than in other institutions admitting women. This may have been because of the unique purpose of the schools, that of training teachers regardless of sex, or because the normal schools were perceived as high schools, in which coeducation had already become the rule (Ogren, p. 26). For whatever reason, men and women shared experiences in normal schools at a time when American higher education, even in the coeducational institutions, was segregated by sex.

\section{The New South}

The historical reality of the lives of southern women has been obscured by a series of characterizations which have near-mythical status. While the southern lady, the belle, the flapper, and the poor white woman struggling to feed her children on a tenant farm or in a mill town had their counterparts in real life, the truth was both simpler and more complex. Southern women lived circumscribed lives, but many actually had more freedom after the disruption of civil war than did their northern sisters, restricted by the doctrine of separate spheres. In the aftermath of the war, hundreds of thousands of southern women were forced to earn their own, and their families', bread by whatever means possible and northern 
women were frequently surprised to find that southern women ran farms, stores, and businesses. Still, family and community exerted great control over the lives of southern women (Friedman, p. 99). The end of the nineteenth century brought American capitalism, railroads, and technology to the South, but gender roles changed slowly (Friedman, p. 110). The activity of the New South created new opportunities for women to be independent, but most southern women continued to enter the public arena only through avenues which were traditional to women (Friedlander, p. 74).

As conditions improved after the Civil war, Southern women with leisure time joined voluntary associations. In the 1870s, these were church and missionary societies (Wheeler, p. 9). During the 1880s, the Women's Christian Temperance Union's prohibition campaign attracted millions of Southern women. Temperance societies put Southern women into mainstream American life (Thomas, p. 76). In the 1890s, women established literary societies. By 1900, these societies changed their focus from selfimprovement to working for reforms, including education, suffrage, and protection for children (Thomas, p. 76), Progressive reformers urged women to participate, as long as the women behaved properly (Rieff, p. 135). The movement of southern women from the home into the public arena depended at least in part on support from men, so 
these women were careful to maintain the appearance of traditional femininity (Fox Genovese, p. 234).

By end of the century, southern clubwomen participated in a number of reform movements. An extensive agenda for reform embraced moral and humanitarian causes. Women worked to reform education, to enact child-labor laws, to promote and improve public health, to abolish the convict leasing system, to prohibit the sale of liquor, and to improve the status of women. Southern women actively campaigned for the reform of statutory laws, especially the "age of consent" laws (Henry, p. 355). Several southern states had strong state suffrage associations in the 1890s, and by 1914 all the southern states had active associations. Southern suffragists campaigned for educational reforms, as they believed the condition of women to be closely tied to educational access.

A surprisingly high number of women in the "New South" were gainfully employed. The movement of women into the working world was born of necessity and changing economic conditions (Scott, p. 129). Women living in the country had few opportunities to earn money, so a widowed, unmarried, or abandoned farm woman was likely to sell the farm and move into one of the new towns to work. In some textile mill towns, half of the employees were women. Most white women attempted to reserve work for 
the time between school and marriage. Women under the age of twenty four were likely to work as domestic servants, mill hands, or teachers. Married women found that they could sew and still watch children, so many women worked as dressmakers, milliners, or seamstresses (Ayers, p. 77). Even well-bred women worked in box and cigarette factories ( Scott, p. 121). Southern women also supplemented family income, or maintained a home for their children, by taking in boarders. Women's clubs made impressive efforts to help working women, especially those caring for children and parents, by finding them housing, jobs, or assistance while unemployed (Ayers, p. 77). The records of the New orleans social and Industrial Association for 1887 and 1888 indicated the variety of jobs that southern women held. During that year, the association found jobs for women as teachers, stenographers, librarians, typists, bookkeepers, canvassers, housekeepers, dressmakers, cashiers, clerks, saleswomen and nurses (Scott, p. 123).

The most admired professions for southern women were teaching and writing. While relatively few women could become journalists or novelists, schools offered highstatus jobs to women. The surge of interest in education in the South coincided with the need of large numbers of women to find paid employment. Contemporary observers often commented on the numbers of well-bred southern 
women who taught (Scott, p. 111-112). As public schools spread across the South, every new schoolroom created a new job for a woman, multiplying opportunities for poor but bright girls to get an education and respectable work (Scott, p. 115). The educational movement also created opportunities for women to teach or study in the state normal schools (Wheeler, p. 9).

"New Women" appeared in the South as they had elsewhere in the United States. Southern women took up tennis, rode bicycles, and demanded reforms and greater opportunities (Ayers, p. 316). Still, most women in the South continued to believe that their families were their highest calling and to adhere to traditional roles. The social ferment and opportunity of the times encouraged women to step out into public life, but even as they did so, they continued to behave so as not to threaten existing social structures.

The Educational Movement in the South

Southern reformers at the end of the nineteenth century began a revolutionary crusade to attack the deplorable condition of public education in the South. The history of southern education began with the English aristocrats who settled the Chesapeake Bay. Their fear of educating the common people affected the attitudes of southerners toward education for centuries. Gentlemen 
cultivated education for themselves but believed, as had Francis Bacon, that if schooling was too easily available "many persons will be bred unfit... which fills the realm full of indigent, idle, and wanton people" (Fischer, p. 348). Planters provided tutors for their children and in the towns merchants and professionals supported private academies. Young women of the elite attended "adventure schools" run by widows or unmarried women who taught the students French and fancy embroidery (Farnham, p. 37). In the southern backcountry, the Scotch-Irish settlers struggled to maintain small schools by private subscriptions, which were taught a few weeks a year by traveling schoolmasters. While settlers expressed their concern for the education of their children, circumstances often defeated them (Fischer, p. 723).

After the Revolution, private educational facilities in the south continued to grow. Wealthy young men attended fine private colleges, while in the backcountry, a literate elite trained for the ministry in Presbyterian academies. Well-off southerners desiring prestigious classical educations for their daughters supported a surprisingly high number of women's colleges of high quality. Between 1850 and 1859,32 of the 39 chartered female colleges in the United States were in the South, and Florida was the only southern state without a women's college (Farnham, p. 18). A stigma surrounded publicly 
supported education because of the regional emphasis on education as a parental responsibility and the extreme individualism cultivated by Southerners. Southern cities and larger towns provided education for the children of the poor in "pauper schools," but in order to attend, students had to take a pauper's oath. Social disapprobation and the demeaning surroundings discouraged children of poor and middle-class families from attending these pauper schools. Despite this, literacy rates in the South slowly rose. By 1861, Southern literacy was comparable to that of the Midwest (Encyclopedia of Southern Culture, p. 237).

During the Civil War, a few schools struggled to stay open, but by 1865 education in the south had effectively collapsed. A few men's colleges reopened soon after the war, but the women's colleges would not regain their former status until well into the next century. There were no public schools, nor was there any "law nor sentiment" requiring them (Connor, p. 170). Northern evangelicals, teachers, and Republicans saw the restructuring of southern educational systems in imitation of the North as a first priority. Radical Republicans argued that the best way to regenerate the South was through the dissemination of Northern culture and values in the schools, and imposed northern common school systems in the seceded states. Hundreds of young 
women teachers eager to help the freed slaves came south under the auspices of the Freedmen's Bureau. Congress insisted that provisions for free universal education were absolute requirements for readmission of the southern states to the Union (Link, 1986, p. 8). Radical legislatures in the former states of the Confederacy passed laws guaranteeing state-supported schools for children of both races, authorizing taxation for the support of the schools, and establishing state departments of instruction (Dabney, 1936, Vol. I, p. 26).

As Reconstruction ended, Southern Redeemer governors and legislatures acted quickly to rid their states of every aspect of Republican control. Reconstruction succeeded in awakening southerners to the idea of universal education, but public education had been so badly stigmatized as a northern imposition on southerners that it was first to suffer the consequences of "retrenchment." Governor Holliday of Virginia called public schools a "luxury"; editorials condemned the schools as an importation of a "gang of Carpetbaggers." Reaction throughout the South crippled the schools, which were then dealt further blows by the terrible poverty of the region (Woodward, p. 61). All of the southern states instituted, or re-instituted, segregated schools and mercilessly slashed school budgets (Cremin, p. 25). Long- 
held attitudes towards learning and dislike of mass education, which threatened intensely individualistic and familial southerners with state control of the raising of their children, made southerners extremely reluctant to maintain state school systems (Cremin, p. 7). The planters, merchants, and industrialists who controlled Redeemer governments were notoriously hostile to public education for blacks and poor whites (Gershenberg, p. 419).

The condition of southern education in the last decades of the nineteenth century was truly dismal. Walter Hines Page, a North Carolinian writer living in New York, stated that the South was the most backward place in the entire English-speaking world (Link, Country, p. 84). In 1880, the average school-age child in the South received only 23.6 days of school a year, while in the North children attended an average of 71 days (Gershenberg, p. 413). Every southern community had a schoolteacher, but most of these teachers had barely more education than their students. A West Virginian commented that the rural teachers were as childish in their tastes and "quaint" in their ideas as the students (Smart, p. 157). White teachers stayed in a school an average of three years, black teachers two and a half, and the high turnover among teachers meant that classrooms had inexperienced and untrained teachers. 
Students met in decrepit schoolhouses for terms of ten to twelve weeks, often during July and August when farm crops needed less work (Ayers, p. 211). When Redeemer governments took office in the $1870^{\prime} \mathrm{s}$, school spending fell drastically. In the South Atlantic states, annual per-pupil expenditures of $\$ 10.27$ in 1871 fell to an average of $\$ 6.60$ in 1880 (Woodward, p. 62). The South's high birth rate meant that southerners had twice as many children to educate, while its devastating poverty meant that they had half as much income with which to do it. In 1880 , a third of the whites over the age of ten in North Carolina were illiterate, as were a fourth of whites over ten in Tennessee, Kentucky, Alabama, South Carolina, and Georgia. Black illiteracy rates in 1880 ranged from a low of 70 percent in Kentucky to a high of 82 percent in Mississippi (Ayers, p. 418). In 1885, only 58.5 percent of school-age children in the South were enrolled in any kind of school (Dabney, 1901, p. 63).

Still, an awakened interest in education could be discerned in the south. In each state a few reformers campaigned tirelessly to better the schools, assisted with small endowments from northern philanthropists (Woodward, p. 61). Industrialization, the railroads, expanding commerce, and growing towns began to bring the South of the $1880 \mathrm{~s}$ closer to the rest of the nation. Younger businessmen, professionals, and teachers urged 
state legislatures to pass laws providing for more schooling. By 1890, Southern states, Florida among them, began to open high schools and normal schools for the training of teachers and to examine the condition of schooling throughout the region.

The educational situation during the last decade of the nineteenth century shocked these reformers. In 1900, despite modest improvements, southern schools were still "miserably supported, poorly attended, and wretchedly taught." School expenditures ranged from a low of four cents a day per child in Alabama to a high of ten cents in Florida and Texas (Wooodward, p. 398). Teachers of ten had to furnish their own supplies and serve as their own custodians in schools that frequently had no wells or privies. Attendance at the miserable rural schoolhouses fluctuated according to the weather, farm work, and the illnesses which plagued southern children (Ayers, p. 212). While the school term lengthened slightly after 1880, no state supported terms of even 100 days. Only one southern state had compulsory attendance.

The difficulties of educating southern children were unique. Eighty percent of the population in 1900 lived in scattered rural areas. Josephus Daniels wrote that "people who live in compact communities can have little appreciation of the obstacle to adequate public schools to be found in a sparse population" (Daniels, p. 314). 
The financial burden of supporting two separate school systems mandated by segregation has probably been exaggerated, because state expenditures for black schools was minimal, but the double school system resulted in less for children of both races as well as making white taxpayers reluctant to support the schools at all (Gershenberg, p. 414). A southern minister wrote in 1901 people who worked for "civilization and enlightenment" were opposed by "others that work for barbarism, some coming...from the negroes... and others from the lower order of whites" (Dickerman, p. 17).

The teaching force in southern states had been feminized by 1900 to a degree comparable to the rest of the nation. In 1889, of 38,703 teachers in the South Atlantic states, 18,462 , or 48 percent, were women (Mayo, p. 167). In $1900,30,968$ of the 44,883 , or 67.5 percent, of teachers in the South Atlantic states were women (Census Bureau, 1905, p. 19). Women teachers in the South, as elsewhere, earned substantially lower wages than men, although not always without protest (Berkeley, p. 45). Southern women taught because they needed to work, but many also were motivated by a conviction that they could promote christian values through child nurturance (Brumberg, p. 383). Observers frequently remarked upon the large number of young women of the "better families" who went into teaching. 
An impressive network of northern and southern school reformers, who believed that only education could remake southern society and reintegrate the south into the nation, came into existence in the last decades of the nineteenth century. The philanthropist George Peabody, a Boston banker, established a trust fund in 1867 to promote and encourage intellectual, moral, and industrial education for the young of the destitute Southern states. Among the first Board members of the Peabody Fund were General U. S. Grant, Senator Hamilton Fish, and Admiral Farragut. Later members included Presidents Hayes, McKinley, Cleveland, and Roosevelt as well as Supreme Court justices, senators and ministers (Connor, p. 170-172).

Barnas Sears, president of Brown University, served as general agent of the Fund from 1867 until his death in 1880 (Connor, p. 173). Sears observed that southerners greeted any proposal to spend money educating teachers with "a cry...that the interests of the children are to be sacrificed" (Connor, p. 178). Instead of training teachers, the Peabody Fund at first gave aid to schools "in proportion to the influence they would exert on the general system" because sears believed it wise to "aid those most who help themselves most" (Connor, p. 174).

J. L. M. Curry of Alabama succeeded Sears in 1880 as general agent of the Peabody Fund. Curry used the 
Peabody Fund to develop teacher education. He evangelized for teacher training in meeting houses all over the South and established Peabody funded teacher institutes, bringing in the most prominent educators of the times. The institutes were planned to serve as models for other southern states. Speakers emphasized the role of teachers as "missionaries of ideas" in southern rural communities. The teachers in attendance were urged to cultivate a strong sense of duty both in themselves and in their students. The Peabody agent believed that southern individualism had to be challenged by the schools, and the institute curriculum emphasized that the schools should prepare children for life with other people, because "the spirit of our Government demands harmonious...cooperation with others" (Smart, p. 70, 94).

Curry urged southerners to establish normal schools, describing them as the "capstone of education." By 1892, all the income from the Peabody trust was spent on teacher training, culminating with the founding of Peabody Teachers College in Nashville, an institution which greatly professionalized southern education. Generations of teachers went to Nashville for training. Curry became the elder statesman of education in the South, guiding a young group of leaders who felt that education was the greatest need of the New South. In North Carolina, a group of progressive professionals and 
businessmen, inspired by Curry, called themselves the "Watauga Club" and began to connect with other southerners interested in reform. Education professionals, civic groups, and women's clubs throughout the region had come to believe, for varying reasons, that the schools would save the South (Link, 1986, p. 89). This laid the foundation for the great southern educational revival of 1900 to 1913.

Northern philanthropists were very interested in the South as a field for their own philosophies of social betterment. While southerners frequently ridiculed them as "Pullman car philanthropists" and "the swell belly parade" (Harlan, p. 198), these philanthropists expressed a sincere desire to reintegrate the South into the nation and supported ambassadors, men known as "intersectionalists," who bridged the gap between North and South through a common interest in education (Link, p. 82 ).

In 1898, a select group of Christian ministers and educators met in Capon Springs, West Virginia, to discuss Christian education and the education of blacks and mountain whites. They called their group the "Conference for Education in the South," and began to hold annual meetings. Robert $\mathrm{C}$. Ogden, a New York department store magnate and evangelical Presbyterian, attended these meetings and in 1901 invited his fellow philanthropists 
John D. Rockefeller, Jr., Frank Nelson Doubleday, and V. Everit Macy to accompany him in a luxurious private train car to the Fourth Conference for Education in the South (Cremin, p. 218). These men have been accused of being motivated by interest in protecting their southern investments, but they demonstrated a sincere concern for improving the conditions of southern life and education (Link, 1992, 129). The public school was the lever by which all the many other problems of the south would be solved (Harlan, p. 192).

At the 1901 meeting in Winston-Salem, the Southern Education Board, or SEB, was founded with both northern and southern members. Curry was elected the supervising director of the Board (Cremin, p. 219). Many evangelical Christians served on the Board, and the central component of the evangelical world view, the conversion experience, shaped the philosophy and activities of the SEB's campaign. Reformers sought to bring about social change by first changing individuals, "converting" them to the cause of education (Link, 1986, p. 100). The SEB was sustained and supported by the General Education Board, founded by Rockefeller, which in turn had been patterned on the Baptist Education Society (General Education Board, p. 7). The SEB styled its campaigns as "crusades" which would bring the people to the cause of education, and sought to convert the south to education by using 
newspapers, popular magazines, and revivalist meetings (Cremin, p. 218).

Southern and northern progressive educators agreed on four essential reforms: the promotion of socially useful schooling, the use of schools as community centers, the depolitization and professionalization of schools, and the encouragement of scientific pedagogy based on the new social sciences (Cremin, p. 223).

In the South, where reformers saw the deficiencies of schools as the reflection of a greater social malaise, school campaigns had unique regional characteristics. The Board deliberately chose to neglect the cause of education for blacks, stating that black children would best be served by first establishing good public education for whites (Harlan, p. 198). The zeal that animated the crusade for education in the South reflected the southern love of religious revivals as well as a uniquely regional mixture of paternalism and noblesse oblige (Woodward, p. 401).

The campaign swept the South. Charles Dabney, president of the University of Tennessee, opened the Board's Bureau of Information at Knoxville in 1902. By 1903 the Bureau regularly mailed handouts to 1,700 newspapers in the south and printed thousands of circulars, bulletins, and reports for use in the state crusades (Woodward, p. 403). The SEB campaigned for 
voluntary local taxation for the schools, improved schoolhouses, higher salaries, longer school terms, compulsory attendance, and rural school consolidation (Woodward, p. 402). Progressive governors and legislatures elected in southern states enacted laws which established state control over educational systems and raised standards. School expenditures in the South tripled between 1900 and 1913 (Woodward, p. 405).

The reformers genuinely believed that education would contribute directly to individual prosperity, economic development, widened democracy, and the liberation of southern women and men of both races from the bonds of ignorance (Grantham, p. 257). Southerners were persuaded that education was the proper machinery for social amelioration, whether the problem to be attacked was hookworm, poor housing, or superstition (Grantham, p. 246).

Women benefited greatly from the movement for southern education. Most southern state universities excluded women, but women could attend the new normal schools for teacher training. Others studied domestic science in women's colleges, and then worked as teachers or extension agents (Grantham, p. 269). Normal schools produced a growing number of college-educated women interested in education who would have great influence in the South (Ayers, p. 212). Urban middle-class club women 
organized and enthusiastically supported the educational campaigns and pushed for expanded opportunities for higher education for women. Not only did these women enter the public arena during the crusade for southern education, but they also had a tremendous impact on the course of southern education in the twentieth century (Link, 1992, p. 134).

Conceptual framework

The study of the Florida state Normal College at DeFuniak springs was conceptualized as a case study which, in addition to contributing to knowledge of this particular institution, would add to understanding of the development of Florida's system of higher education, of the roles of women, of American normal schools, and of the progressive educational movement in the New South. A number of questions guided the research.

1. What factors led to the founding of the Florida State Normal College?

2. What were the social, economic, and academic characteristics of the students? How were they comparable to other students enrolled in institutions of higher education during this time period?

3. What were the fundamental aspects of school life at the Florida State Normal College?

4. What role did the presence of these students and 
this institution play in the development of a modern system of education in Florida?

5. Is it possible to determine what became of these students after college? If so, what was the impact of their education at the college on their future activities?

6. How did the institution and its students reflect the dominant trends in American education? What can the study of the Florida state Normal College add to our understanding of gender roles, education, and progressivism in the New South?

Certain recurring themes which emerged during the review of the literature comprise part of the essential conceptual framework for the study of the Florida state Normal College at De Funiak Springs.

First, normal schools were extremely important institutions for their dual role as institutions which offered higher education to American women and which functioned to professionalize the teaching profession. Their immense popularity and growth between 1880 and 1920 attest to the centrality of their role in the American educational spectrum.

Second, the feminization of teaching, the growth of the public school system, and the expansion of higher education for women are inter-linked and the history of one cannot be effectively understood without reference to 
the others.

Third, American society during the last decades of the nineteenth century and up to the beginning of the First World War was patriarchal and traditional. The widely accepted notion that developed in New England earlier in the nineteenth century of "separate spheres" for men and women sharply limited the public lives of women. Within these limitations, women acted practically and many sought to improve their, and their daughter's situations, by moving into socially accepted fields of endeavor and education outside the home. Teaching, domestic science, and social work did not violate traditional gender roles and became fields for which young women could educate themselves while maintaining adherence to proper behavior.

Fourth, Florida was culturally and historically a southern state, and educational history and institutional development in southern states was different from that of other regions of the United states. The uneasy coexistence of two races, the dispersed rural population, southern localism and adherence to tradition, the devastation of the Civil War, and the extreme poverty of both white and black southerners made Florida and the rest of the South unlike any other region. Any historical research of a southern educational system which ignores this is ahistorical and unreasonable. 
The Florida state Normal College was uniquely situated in both time and place to fill gaps in the history of American education that are of great interest and importance. The story of this small school open for less than twenty years contributes to the history of normal school education, of southern educational systems, and the education of women, adding to the broader history of American education. The study also adds to our knowledge of the beginnings of higher education in Florida and of the present higher educational system. Further, the study illuminates trends in the southeastern United States, and, to some degree, increases our understanding of other regions as they affected education in Florida. 


\section{Methodology}

Methodology

The methodology of historical investigation has long been established. Historical research emphasizes the necessity of seeking the truth while allowing minimal bias on the part of the historian to affect the accuracy of the research. This is done by rigorous adherence to the procedures which have been developed for properly conducting historical research. The framework of this study is the already developed approach to archival historical research and analysis in the United States. An overall objective of the present study was to use this framework in the study of the Florida state Normal College for white students, an area in which no previous study has been made.

For purposes of this study, after identification of the area of interest, a thorough survey of possible sources of information was conducted and the systematic, objective collection of primary sources begun. Primary sources compiled for this investigation included

1. Archival materials from the Florida State Normal College.

2. Catalogs from the Florida State Normal School and other contemporary Florida institutions.

3. The complete record for the Twelfth Census of the 
United States and other census materials.

4. Descriptions and discussions of American education appearing in journals, newspapers, and official reports during the time period that the school was open.

5. The annual reports of the Commissioner of Education of the United States.

6. The Biennial Reports of the Florida Superintendent of Education.

7. Photographs, brochures, and other primary sources.

The search for primary sources to illuminate the subject of a study is one of the most challenging aspects of historical research. Extensive efforts were made to locate further sources by making contacts with local historical societies, local newspapers, genealogists, historians with a special interest in Florida, and special collections librarians in Florida, and a number of documents from private sources became available during the writing of the study and were extremely valuable.

The task of collecting materials was then followed by the determination of their validity, and consideration of the possible bias of the materials collected, as well as their presumed accuracy. Close comparison with other available sources was carried out at this point in the 
investigation. Following this step, sources were compiled in order to reconstruct the actual events, situations, and actors involved in the study. At this point in a historical investigation, new perspectives typically begin to emerge, which lead to historical interpretation as the researcher examines all the data collected and places it into context in the search for meaning. The historian then synthesizes the research and a narrative emerges.

An original aspect of this study was the examination of the complete record for Florida of the Twelfth Census of the United States, taken in June of 1900. A substantial number of the students enrolled in the normal school between 1897 and 1905 were found on the Census, and valuable information was collected. Comparisons of the material taken from the census and other materials gathered yielded previously unknown facts and descriptive statistics about the students of a hundred years ago in Florida.

All writers of history seek objectivity. However, as the research process involves judgment in the selection and use of materials, it is almost inevitable that observer bias on the part of the researcher will emerge. One piece of data is selected, rather than another, and there have been many omissions in the historiography of American education. While it may be 
impossible to maintain absolute objectivity in historical research, the careful following of the steps outlined, followed by peer review, can effectively control, if not eliminate, bias in research.

\section{Assumptions}

A basic assumption made in order to carry out research of this nature is the validity of the archival historical method. Careful use of the data obtained enabled the researcher to fill in a number of gaps in our knowledge of the development of higher education in Florida.

\section{Limitations}

This study was limited to one institution, the Florida State Normal College at De Funiak Springs, which was open between 1887 and 1905. Because of the time that has elapsed between the closing of the institution and the present study, the sources used for the study were available written documents, photographs, and statistical materials, all of which were primary sources. Therefore the study was limited to relevant documents which were accessible during the course of the study. 


\section{Results of the study}

The Historical Background

As the nineteenth century ended, several historical developments converged which would result in the establishment in 1887, and the closing in 1905, of the Florida State Normal College at DeFuniak springs. Massive changes in the common schools of the United States created a huge demand for teachers, which women were eager to fill. The changed nature of the teaching profession and its consequent professionalization intersected with changes in the status, education, and lives of American women. Modernization and the introduction of northern capitalism in the south transformed southern society, leading to a series of reform efforts of which the crusade for educational reform was the most significant. Therefore, in the following sections, each of these major elements will be discussed in depth as it applies to the Florida state Normal College. 
Life in Florida

Florida had no educational system for many years. When Andrew Jackson, the first territorial governor, raised the American flag at Pensacola in 1821, Florida was a frontier outpost manned by a few spanish garrisons. The original Indians had disappeared and only runaway slaves, a few settlers, and about five thousand seminoles lived in Florida two hundred and fifty years after the Spanish colonized it (Tebeau, p. 133). As immigrants ventured into the new territory the original population of 8,000 grew. By the 1830s, the territory boasted of 34,530 residents, living in a few towns and cottonproducing counties in the northern portion of the state (Gannon, 1993, p. 30). In 1845, when Florida entered the Union, its population was 56,000 . By $1860,140,000$ residents, nearly half of them slaves, lived in a state dominated by cotton planters and ranchers (Gannon, 1993, p. 40). In 1861, Florida followed the other southern states into the Confederacy. Fifteen thousand white male Floridians served in the Confederate armies; five thousand did not return. Although these losses are small compared to the horrendous numbers of dead and injured in the war, Florida experienced deprivation, loss of manpower, and defeat. The former slaves abandoned the plantations and after the war both black and white had to find new ways to live together, yet apart (Tebeau, p. 
236).

Military Reconstruction began in Florida in April of 1867 (Tebeau, p. 247). The state wrote a new Constitution and reentered the Union in 1868 . Reconstruction did not end until 1877, when George Drew, a Democrat, was elected governor. "Millionaire Drew" typified the southern white conservatives who formed Redeemer governments. Florida's "Bourbons" were determined to restore their fortunes and importance, to return the freed slaves to powerlessness, and to "retrench." Drew declared that the guiding principle of his administration was to "spend nothing unless absolutely necessary" and drastically slashed expenditures of every kind (Woodward, 1951, p. 58-59).

The end of Reconstruction marked the beginning in Florida of rapid expansion and change. Floridians moved southward into previously unoccupied regions, and northern capitalists made huge investments in the state's railroads and extractive industries. Floridians from cities, villages and farms tried to modernize and become part of the "New South." The themes of New South boosters - cheap resources, business opportunities, railroads, and commerce, were echoed throughout the state (Ayers, p. 6). Florida avidly courted Yankee money. Harriet Beecher Stowe observed in 1877 that "about all the money circulating in the state comes from Northern 
immigrants and visitors" (Woodward, p. 20).

Three railroad magnates built thousands of miles of track in Florida. William D. Chipley extended the powerful Louisville and Nashville Railroad to west Florida. Henry Plant connected Jacksonville to Tampa, opening the interior of the state to agriculture. Henry Flagler extended his East Coast Railroad all the way to Key West, building hotels and bringing visitors as he went. The railroad barons profited from state largess, receiving millions of acres of public lands from the Florida legislature. In 1884, an observer wrote that although the public domain had never been larger than fifteen million acres, the legislature had given away nearly twenty-three million (Woodward, p. 117).

Northern lumber interests arrived with the railroads. As northern forests were logged out, companies sent "cruisers" south in the 1880 s to locate stands of long-leaf pine in states with a propensity for giving away their public lands. In 1882, a cruiser from Michigan wrote that the woods of Florida were full of men like himself, sent on the same errand (Ayers, p. 124). The arrival of the railroads turned lumbering into a year-round business. New towns grew as the forests were stripped.

The turpentine and naval stores industry followed the rail lines deep into Florida's piney woods. Fifteen 
thousand laborers, mostly black, traveled through the forests chipping wounds into trees and returning to collect the "dip." The primitive methods in use further destroyed once endless forests, which disappeared at an alarming rate all over the South (Ayers, p. 124).

In the 1890 s enormous phosphate beds were discovered in Florida. Phosphate prospectors loaded down with spades, chemicals, and camping gear filled the woods. The forests were torn by buggy wheels and "punctured like a sieve" by the twenty-foot long sounding rods the prospectors used. By 1900, phosphate companies operating deep in the woods used convict labor to dig and mine huge pits. The phosphate was then dried by burning uncountable cords of wood from the surrounding forests (Ayers, p. 110).

Along with industrialists and mining companies came the tourists. Before the civil War, northern consumptives traveled to Florida to winter in Jacksonville or St. Augustine in hopes of improving their health. By the end of the century, tourists traveling for recreation had joined the health-seekers. A visitor to Jacksonville in 1896 wrote that dance music spilled from the entrances to brightly lighted hotels, and that the city could "easily be taken" for a northern resort (Ayers, p. 61). In 1888, Henry Flagler built the magnificent Ponce de Leon Hotel in St. Augustine, which 
attracted the wealthy for a quarter century. By 1896, his palace cars rolled through the dusty poverty of the South all the way to the Royal Palm Hotel in Miami (Woodward, p. 297).

Other industries thrived as well. Citrus, first introduced by the spanish, could now be loaded on railroad cars and sold in far-away markets. The importance of this cash crop grew yearly. Cigar factories in Tampa and Key West supplied aficionados of Cuban cigars throughout the United States.

Still, the new Florida had serious problems. The capital investments came with a high price. Vast acreages were given away in return for extractive industries which enriched capitalists living far from Florida, in the North or even in England. Low-wage, unskilled production or the extraction of raw materials characterized Florida's new industries. Florida produced cotton, phosphates for fertilizers, sugar cane, citrus, turpentine, and lumber (Woodward, p. 309-311).

Florida had no system of penitentiaries. Instead, Florida, like other southern states, leased convicts, mostly black, to the turpentine and phosphate companies hidden deep in the woods. Rumors that foremen ran the camps with ghastly brutality did not stop the practice of convict leasing, which continued in Florida for many years. Race relations worsened as blacks and whites 
competed for subsistence wages in fields, mines, and mills (Woodward, p. 211). Florida's Gulf coast led the country in lynchings, with twice as many as Georgia, Mississippi, or Louisiana, and three times as many as Alabama (Gannon, 1993, p. 87). Lynchings somehow seemed "more necessary and more feasible" in places like the new Florida, where blacks and whites did not know each other or share the ties of generations (Ayers, p. 157). Jim Crow laws enacted by the 1887 legislature removed the few legal protections the black citizens of Florida had. This same legislature had six black members, who would be the last black legislators until 1968 (Gannon, 1993, p. 56).

In the first years of the new century, reform movements swept the nation. "Progressives" campaigned for state intervention in education, public health, child welfare and public morality. Reformers found much to do in Florida, for in addition to racial conflict, convict labor camps, and lynchings, Floridians were poor. In 1890, half the men in Florida worked in agriculture, which was plagued by declining prices and bad weather throughout this period. In 1900, a fifth of Florida farmers were tenant farmers (U.S. Census office, Farm Tenancy, p. 148). In 1900, Florida properties were valued at 389 million dollars, the lowest of any southern state. Florida's bank deposits of $\$ 5,531,000$ were less 
than any other southern state except Arkansas (Hart, p. 400-402).

Florida also had public health problems. Typhoid fever and other infectious diseases were endemic, hookworm constantly plagued Floridians, and yellow fever raged through the state in 1887 and again in 1888 (Gannon, 1993, p. 62). In 1904 Florida had 1200 prisoners, of whom nearly 1100 were black, and 740 mental patients who required hospitalization at the Chattahoochee Hospital for the Insane (Hart, p. 406). Florida legislatures were extremely resistant to child labor legislation. While no textile mills operated in the state, in 1909 the Tampa cigar factories still employed over a thousand children. (Grantham, p. 198).

Many reformers trusted that the prohibition of alcohol would cure Florida's social ills. Others, however, came to believe that the real solution for Florida's problems was educational reform.

Education in Florida

Despite encouragement from the national government, public education in Florida had advanced at a snail's pace. The Northwest Ordinance of 1787 set aside a sixteenth section of each township in the new territories of the West in order that "schools and the means of education shall be forever encouraged" (Bush, p. 30). 
When Florida became a territory, Congress reserved the sixteenth sections, or six hundred and forty acres, in every township for the schools. In addition to this handsome endowment, the 1823 Congress gave Florida two townships, or 46,080 acres, to be used for the support of seminaries (Pyburn, 1959, p. 3). In 1835, Congress gave more lands to the territorial government to support the establishment of a proposed university. When Florida became a state in 1845, Congress donated two more townships, specifying that the lands be used to establish two seminaries, one in east Florida, and one in the west (Stakenas, p. 26).

The territorial council did little for twenty years to use the school lands, but interested citizens in Tallahassee formed a Florida Education Society in 1831 to promote the establishment of a school system. The society raised funds for a school for manual and agricultural arts, but the school never materialized and the society disbanded (Bush, p. 12). In St. Augustine, a branch of the society compiled information on the local schools and determined that of 351 school age children in the area, only 57 attended regular schools. Thirty apprentices received two hours a day of instruction, required by a territorial law of 1822 (Verner, p. 29 and Dabney, Vol. I, p. 327).

Governor Moseley in 1846 stated that squatters had 
lived on the school lands for years and that the rents had been "squandered" (Dabney, Vol I, p. 327). He appointed Thomas Baltzell to head a commission to investigate the disposition of the school lands. Baltzell reported that the sixteenth sections in the townships were "wasted and worn out." Valuable timber had been cut and destroyed and the lands had been "exhausted by private and individual rapacity" (Pyburn, 1959 , p. 6). Baltzell further reported that only 26,000 acres of the original seminary grant of over 46,000 acres had even been surveyed. He sent surveyors out to locate the lands, and after they completed the survey he sold some lands and leased others, using the money to establish a trust fund for education (Stakenas, p. 25). Florida in 1840 had approximately nine thousand school aged white children, but only 732 students were reported in the entire territory. Given those circumstances, Baltzell believed the school income could best be invested in libraries (Pyburn, 1959, p. 6-7).

The new legislature passed Florida's first real school law in 1849, establishing publicly supported education for all white children aged five to eighteen. Indigent and orphaned children would not have to pay any tuition. The law authorized the residents of each township to elect three trustees to use the income from that township's school land for public schools. Five 
percent of the sales tax on public lands and escheated properties was allocated to the school fund, and the Registrar of Public Lands became the ex-officio superintendent of schools (Tebeau, p. 195-196). At the time, Tallahassee had a free school and a few counties supported public schools for terms of three months a year. Planters in Florida, as elsewhere in the South, hired tutors for their children. Although by 1850 state officials had acknowledged the need for a comprehensive common school system, Florida had only sixty-nine public schools, with an enrollment of 3,129 (Dabney, I, p. 329). The state received $\$ 17,000$ that year in income from the seminary lands (Pyburn, 1954, p. 9).

A bill sponsored by Owen Avery in 1851 formally began state-supported higher education in Florida. Avery's bill authorized the establishment of two seminaries, one in the east and one in the west, for the purposes of teacher education, and education in agriculture, vocations, and citizenship (Pyburn, 1959, p. 21). The town of Ocala formed the "East Florida Independent Institute" in 1852 and offered it to the state as a home for one of the seminaries. The state accepted, and in 1853 the East Florida Seminary opened in Ocala, where it conducted classes until 1866, when the legislature moved the seminary to Gainesville. Tallahassee residents opened the "Florida Institute" 
hoping that it would house the western seminary. The legislature approved, and the west Florida seminary opened in 1856 (Stakenas, p. 27-28). The seminaries planned to offer anatomy, astronomy, chemistry, science, animal husbandry, literature, history, moral philosophy, mechanical arts, and agricultural chemistry as well as a twenty-week training course for teachers (Tebeau, p. 196).

In reality, poverty and the lack of qualified teachers and students meant that the East Florida Seminary was no more than an elementary school, while the West Florida Seminary was an elementary school with an added high school (Bristol, 1952, p. 14). State education superintendent John Beard argued in 1850 that a "superstructure" of higher education remained many years in the future, and that the state should offer its young citizens practical studies. Beard believed that state-supported study of the classics would turn thousands of young Floridians into "drones" and lead to individual suffering and crime (Pyburn,1954, p. 14).

In 1858, the East Florida Seminary had sixty-five students, of whom three were women who planned to teach. The West Florida Seminary had 200 male students at that time, and a separate female department enrolled 112 young women within weeks of opening (Pyburn, 1959, p. 35-36). Despite the apparent interest of young women in the state 
in furthering their educations, Florida was the only southern state with no female college in 1860 (Farnham, p. 18).

Throughout the $1850 \mathrm{~s}$, the schools made small gains. By 1860, there were ninety-seven public schools, enrolling 4,486 white students, although the average daily attendance was less than half that (Dabney, I, p. 329 and Bush, 19). The Civil War destroyed Florida's tiny system of public education. The legislature used the school and seminary monies to equip Florida's military regiments. Teachers enlisted, and school buildings fell into ruin.

At the end of the war, a few planters and other private citizens made an attempt to revive the schools, but the beginning of military Reconstruction in 1867 crippled these limited attempts (Knight, 1922, p. 337). Although the Florida constitution of 1868 authorized a uniform system of public schools, it was not until 1879 that the devastated schools could even be surveyed and a new beginning made. The superintendents of education during the years following Reconstruction attempted to survey the condition of Florida schools. They complained bitterly that school officials in many counties did not even return their questionnaires, but what is known about the state of Florida's educational system during those years is uniformly dismal. 
Probably only twenty five public schools were open in 1870. Of the whites over the age of ten, 27.6 percent were illiterate, as were 84.1 percent of the blacks (Rosen, p. 313). The impoverished blacks had to pay a tax of one dollar per man to support the black schools, as well as a monthly fee of fifty cents per child (Tebeau, p. 265). By 1868, the schools sponsored by the Freedmen's Bureau had closed (Verner, p. 32). Although the new constitution did not require separate school systems, there is no evidence of any integrated school in Florida. White Floridians feared mixed schools and were prejudiced against all public schools (Dabney, I, p. 332). Barnas sears, the first general agent of the Peabody Fund, described Florida early in 1869 as "very backward in education" and said there were no schools at all in the rural districts (Rosen, p. 316).

However, in 1870 even sears declared that he was pleased with Florida's newest school laws. Although the state had no money with which to fund the schools, Sears said Florida was now more "advanced" than a number of the other southern states (Rosen, p. 317). Floridians generally favored the new laws, which included several progressive features (Bush, p. 17). The law authorized a state board of education, an elected superintendent, free tuition, a uniform system of common schools, and a university. This was followed in 1870 by the 
authorization of an agricultural college, which eventually opened in 1884 in Lake City (Stakenas, p. 31$33)$.

Still, progress was more apparent than real. Five years after the war ended there were almost no schools in the state. Itinerant teachers who rarely claimed to know more than the rudiments of writing, spelling, and arithmetic, kept school in cabins and out-buildings (Bush, p. 18). The scattered population added to the difficulties of keeping school. In 1870, Florida still had only 188,000 residents, an average of three per square mile. Many lived in such remote areas that no one could educate them (Cochran, p. 72). On Sears's recommendation, the Peabody Fund gave Florida monies equal to eleven percent of the state education budget in 1870 to help train teachers in the larger towns (Cochran, p. 73). Although by 1872 over four hundred schools had opened, enrolling 16,000 students, only a fifth of Florida's school age children attended school (Bush, p. 20 and Goulding, 1959, p. 48).

Samuel McLin, a probable Confederate deserter, served as superintendent of education from 1874 to 1875 and wrote a thorough report on the schools. He recorded that he had discovered that "three out of four teachers are unfit for the place they occupy, in respect to scholarship, methods and principles of teaching, general 
intelligence, and ability to govern and organize a school." County superintendents were political appointees, there was no uniformity in textbooks, and the school buildings were deplorable, even though building plans could be ordered for only a dollar. McLin observed that Florida was the only state without a single institution of teacher training (Rhodes, 1959, p. 56).

In 1877, when Reconstruction ended and Governor Drew took office, public education, stigmatized as a Carpetbag measure, suffered the first cuts during the new era of tax-cutting and thrift known as "retrenchment." The average length of the school term throughout the South declined dramatically. Florida's Bourbons believed that public schools were a luxury, and quoted virginia editor William Royal's opinion that taxation to support free public schools was "socialistic." Retrenchment crippled recovering school districts (Woodward, 1951, p. 61-62). Florida's regressive tax structure, compounded by the extremely low value of Florida properties and bank deposits, impoverished local school districts.

still, a few committed educators struggled to create a better educational future. Governor Drew, despite his avowed frugality, appointed an active, intelligent school superintendent, William Haisley, who traveled the length of Florida for months at a time inspecting, training, and encouraging local schoolteachers. In 1879, Haisley 
organized the first teacher's institutes to be held in Florida, teaching at almost every one.

At Haisley's urging, the East Florida seminary organized a normal department in 1880. Forty one students entered the department in 1881 when it opened in 1881 (Black, 1959, p. 79-82). The West Florida Seminary followed suit in 1883, opening a normal department for any person over the age of fifteen, of good moral character, who intended to become a teacher. Prior academic preparation did not matter (Cochran, p. 74). In 1877, the Peabody Fund began offering a small number of two year scholarships to the two-year program of the Peabody Normal Department at the University of Nashville (Rosen, p. 318).

Although the superintendent's report of 1881 noted that only eight Florida counties had any teachers who held first class certificates, in 1880, eleven hundred public schools had enrolled 38,000 students, and over half were in daily attendance. In 1883, the number of schools had grown to nearly fifteen hundred. Fifty two thousand students had enrolled, and the average daily attendance had grown to seventy percent. Although the school terms averaged only four months a year, these were substantial achievements. In 1884, the legislature authorized $\$ 4,000$ for teacher training, which paid for a number of institutes for both white and black teachers 
(Black, 1959, p. 92-98).

The Constitution of 1885

There was strong support in the gubernatorial election of 1884 for a constitutional convention to replace the Carpetbag constitution of 1868. The new constitution, written in 1885, disfranchised black voters with poll taxes and multiple ballot boxes; stipulated that the legislature would meet every two years rather than annually; and gave Florida an elective cabinet system, unique in the United States (Tebeau, p. 288-289). By the time Florida held the convention, support had grown around the state for a "real" system of education. William Sheats, who later became superintendent of education, lobbied so intensely for progressive educational reforms that other legislators called him the "school crank" (Parker, p. 12-15).

The constitution included important advances in Florida's state supported educational system, written by Sheats. One of these provided for the establishment of normal schools, in Article XII, Section 14, which stated "The Legislature at its first session shall provide for the establishment, maintenance and management of such normal schools, not to exceed two, as the interest of public education may demand." At the next legislative session, in May of 1887, the legislature approved a 
normal school for white students at DeFuniak Springs and one for black students at Tallahassee, providing each with a $\$ 4,000$ annual appropriation for expenses.

\section{DeFuniak Springs and the Chautauqua}

When the legislature authorized the new normal college, DeFuniak springs, founded in 1881 by the Louisville and Nashville Railroad, was chosen as its home rather an older, more centrally located town such as Gainesville or Ocala. The choice of DeFuniak springs as the home for the normal school was almost entirely due to the town-building efforts of one man, William D. Chipley, a director of the L. \& N. in Pensacola and one of the great power brokers of nineteenth century Florida (Proctor, 1996, p. 269). Chipley, a Confederate veteran from Kentucky, came to Florida with the railroad and left his mark throughout the Panhandle.

Scotch-Irish Presbyterians from the Carolinas first settled Walton County early in the nineteenth century. Most of them lived on scattered farms in the area of earlier Indian settlements around Euchee Anna and Alaqua. In 1881, the Florida legislature made an enormous land grant to the Pensacola and Atlantic Railway, which Chipley also directed, to extend a rail line eastward from Pensacola. Chipley accompanied the railway's surveying party. In May of 1881 the surveyors stopped at 
a round spring-fed lake on a high ridge deep in the great forests of West Florida. Moved by the beauty of the spot, Chipley exclaimed, "Here a town shall be built."

The lake was named for Fred R. DeFuniak, an official of the L. \& N. Chipley set apart the land on the rim of the lake as a park, built a railroad station, and marked off lots which the L. \& N. began to sell, capitalizing on the natural beauty of the region. At an altitude of three hundred feet, the town of DeFuniak springs is the highest town in Florida (City of DeFuniak springs Community Information Guide). Investors and speculators quickly bought lots and established businesses with the support of Chipley and his "comrades" (W. L. Cawthon, personal correspondence). In 1883, M. A. Cawthon wrote that he had a "speculation on foot" with Van Kirk, one of Chipley's group. He urged his brother to "be smart so that you can speculate... There is some money to be made...Business is pretty good here and is bound to get better" (M. A. Cawthon, personal correspondence).

The Florida Chautauqua at DeFuniak Springs made the little town an ideal location for the new normal school in 1887. The Chautauqua movement began in 1874 as a twoweek meeting for Methodist Sunday School teachers at Lake Chautauqua in New York. The organizers soon added intellectual and recreational activities for the families of the teachers attending. The chautauqua quickly became 
a uniquely American religious, educational, and recreational movement which was immensely popular and widely copied around the country. People enjoyed lectures, music, food, demonstrations, "crayon" lecturers who drew as they spoke, and "entertainments." In 1878, the Chautauqua began the Chautauqua Literary and Scientific Circle, a sequenced correspondence course whose participants studied a wide variety of books and Chautauqua publications of scientific, cultural and pedagogic value. In 1884, the "Mother Chautauqua" in New York began to search for a similar site for a winter gathering, and sent Dr. A. H. Gillet to Florida to find a beautiful and healthful location where permanent buildings and grounds could be located (Delong, p. 6-7).

The Louisville and Nashville Railroad aggressively marketed the new town of DeFuniak, and in 1884, when a notice appeared in the Jacksonville Times-Union that officials of the great Chautauqua in New York had come to Florida searching for a winter location, citizens of DeFuniak responded with alacrity. C. C. Banfill, an enterprising young man, hurried to Jacksonville to invite the Chautauqua representatives to DeFuniak. Banfill brought the committee to DeFuniak, where, in spite of days of rain and primitive accomodations, the northern representatives decided to locate the new Florida Chautauqua. The first chautauqua, advertised as a 
"winter Assembly in the land of summer," would be held in February 1885, less than seven months away (DeBolt, p. 6). While all the details of this remarkable arrangement are not known, it is certain that the resources, material support, and the enthusiasm of W. D. Chipley and the railroad were instrumental in the selection of DeFuniak as the site (Blazek, p. 380).

Floridians on the board of the new Chautauqua included W. D. Chipley, C. C. Banfill, W. J. Vankirk, W. F. McCormick, and T. T. Wright. The purpose of the group was "to aid in the moral and intellectual culture of the people" (Pyburn, Chautauqua, p. 3). The prospect of a busy town, with a growing population and throngs of northern visitors, created fervent support for the enterprise from local business interests. W. D. Chipley also held the title of general land commissioner of the L. \& N. Railroad, which owned millions of acres of land in West Florida. He, Vankirk, Banfill, Wright, and McCormick formed the DeFuniak Springs Land Company, which incorporated in February 1885. Chipley also directed the Citizens Hotel Company, and he and McCormick were among the officers of the Gulf Ice Company. Fred DeFuniak himself hired another of the group, Vankirk, as a land agent. Banfill was president of the Lake DeFuniak Land Association (Blazek, p. 381-382). Among Chipley's other interest, he was mayor of Pensacola, member and director 
of the State Democratic Committee, a Brigadier General in the United Confederate Veterans, and served on the boards of Stetson University, Florida Agricultural College, and the West Florida Seminary (Pyburn, Chautauqua, p. 37) The directors of the Florida Chautauqua had little time to prepare. They nailed a fourteen-foot pine plank painted with "The Florida Chautauqua First Annual Session will open Feb the 10th to March the 9th, A.D. 1885" to a tree in Chipley Park, where passengers on the train cars going through town would see it. Workers began construction immediately on an asssembly building, or "Tabernacle," and on the Chautauqua Hotel. A local farmer told Banfill that it was foolish to build such a huge structure, and Banfill confidently replied, "Why, sir, we expect to build as much more to it in less than five years" (Mckinnon, p. 358-359).

By the beginning of 1885 , both the hotel and a onestory assembly building awaited the opening of the first Chautauqua. Visitors who chose not to stay at the "Hotel Chautauqua" could stay at the boarding houses local residents opened. Economical visitors purchased cheap lumber from the nearby woods and built temporary shelters on the Chautauqua grounds. Others camped in tents. A take-out restaurant operated by the chef of the Florida Chautauqua School of Cookery, Miss Emma Ewing, provided prepared meals at a reasonable cost to visitors (Pyburn, 
Chautauqua, p. 15). The first Chautauqua had an impressive roster of speakers, including A. D. Mayo and J. L. M. Curry, who were well known in Southern educational circles. At the close of the first day's program, Professor Sherman of the Boston Conservatory of Music told the small audience of one hundred that although "business men, moneyed men" were supporting the enterprise, it had cost over eleven thousand dollars to bring the speakers for the first assembly to Florida. He urged his listeners to "go home tonight, write to your relatives and friends and tell them what a good thing you have here, and ask them to come and see and you will be surprised how many will come to see and stay." Before the first chautauqua ended, it had become the pride of Florida. For years to come, farm families living along any of the railway lines connecting with DeFuniak bought tickets on Saturdays for eighty-five cents and spent the days enjoying the programs and picnicking with the thousands of visitors from outside Florida who attended (McKinnon, p. 360-362). Platforms were built around the lake, and parades, concerts, and illuminations added to the thrill (Jones, p. 12). Scientists at the first Assembly investigated the round lake and determined that it was spring-fed, so Lake DeFuniak became DeFuniak Springs (City of DeFuniak Springs Community Information Guide). The May 1885 Chautauqua wrote: 
The Florida Chautauqua is a success. Four months ago we had a dubious feeling that such an undertaking would fail of any real support in a clime which has always been so averse to adopting progressive ideas. Our healthy Chautauqua tree, we feared, would be enervated by tropical sunshine; but it has taken root with surprising readiness (DeBolt, p. 8).

W. D. Chipley, the driving force behind the Florida Chautauqua, marketed the project vigorously. Two hundred thousand elegant pamphlets entitled "Facts About Florida" and authored by one W. D. Chipley were distributed around the country. Beautifully illustrated with palms overhanging a tranquil beach, the pamphlets enticed northerners to attend the Florida chautauqua (Pyburn, Chautauqua, p. 4 and DeBolt, p. 6). The railroads and steam liners offered special rates to Chautauqua visitors. Special excursion trains ran, and advertisements appeared all over Florida and in the North promoting the climate, food, setting, and cultural and educational benefits of the Chautauqua. Americans believed that springs were rejuvenating, and DeFuniak Springs as a name resonated with physical and mental health (DeBolt, p. 8). Chipley arranged for the railroad to continue to produce brochures, schedules, and booklets 
which included time tables, discount rates, and advertisements for both the town and the chautauqua. The amount of financial support for the Chautauqua was demonstrated by the publication of a weekly tabloid printed in Cincinnati called the Florida Chautauqua. The inaugural issue included an advertisement for the Bonifay Land Company, of which G. W. Banfill (C. C.'s brother) was secretary (Blazek, p. 382). The town did its part to promote a healthy atmosphere for Chautauqua visitors by prosecuting any and all persons who sold liquor or participated in "lewd and lascivious cohabitation" (Weekly Critic, Oct. 24, 1888, p. 4:3).

In October of 1885 , W. D. Chipley wooed another group of visitors to the Chautauqua. He wrote the state school superintendent, A. J. Russell that the Board of Directors had set apart a week of the 1886 Chautauqua for a Teacher's Institute. The program would include the special study of educational subjects, plans, and theories, presented by "intellectual Athletes" and "moral heroes...chosen from the most prominent educational fields North and South" (Pyburn, Chautauqua, p. 7).

Superintendent Russell had already begun to establish two-week teacher training institutes throughout the state. When chipley contacted him about the Institute to be offered at the chautauqua, and then offered teachers a special round trip fare of one half 
cent per mile from anywhere in Florida, Russell convened the first statewide teachers meeting at DeFuniak springs, and even arranged that the teachers should be paid by their districts during their absence at the institute. Two hundred and thirty teachers and superintendents attended (Russell, p. 84). While at the Chautauqua, the assembled teachers organized the first state teacher's association (Florida Education Association, p. 1).

Russell wrote that the new teacher's association could not have been organized without the "enterprise and liberality of the Florida Chautauqua... and every railway and line of steamers in the State" (Biennial Report 18841886, p. 16). The assembled teachers enjoyed a full program. On opening day, speakers included the Georgia Commissioner of Education, educators from Philadelphia and Chicago, and the president of Ohio Wesleyan University (Florida Education Association, p. 7). An added bonus was the Chautauqua Kindergarten, which cared for children every morning except sundays, and offered instruction in the new kindergarten movement to interested teachers in the afternoons (Pyburn, Chautauqua, p. 23).

Chipley offered Florida teachers even more attractive rates for board for the 1887 Assembly, and Russell urged teachers to attend, saying: 
Surely every earnest teacher will avail himself of so excellent an opportunity for improvement... I earnestly desire...all earnest friends of our schools to be present... and witness the grand opportunity afforded through the management of the Florida Chautauqua and the railroads and lines of steamers for the improvement of our school work (Russell, p. 86).

When the legislature authorized the establishment of the normal school in 1887, the new town of DeFuniak Springs became its home, rather than an older town. W. D. Chipley offered the state free use of the Chautauqua buildings so that the new college could open immediately, and guaranteed bargain railroad fares for the faculty and students. DeFuniak's image of educational progress as well as the offer of temporary accomodations and Chipley's influence certainly influenced the choice of location.

Two state normal schools, one for white students in De Funiak springs, and one for black students in Tallhahassee, opened on october 3,1887 , joining a privately owned normal school and business institute in White springs in the new effort to train teachers for Florida's schools. Principal Felkel, formerly superintendent of Tallahassee's schools and a speaker at 
the Chautuaqua, reported that the initial enrollment of sixteen students soon grew to fifty-seven, and that the school had been well-equipped with globes, blackboards, atlases, and other items (Bush, p. 28-29). A new era in Florida higher education had begun.

The Florida State Normal College: Purpose and Curriculum

The Florida State Normal College was established with the expressed purpose of training teachers for Florida classrooms. The principals and faculty of the school struggled to maintain this stated mission, faced with miserly appropriations from the legislature, illprepared students, and persistent accusations that instead of training teachers, the school functioned as a local high school. Arguing the importance of the school's mission, the 1902 catalog quoted United States Commissioner of Education W. T. Harris's statement that normal school graduates continued to grow in professional skill all their lives while others became "pedagogues in the worst sense of the word" (Catalog, 1902, p. 10). The last catalog, for 1904, stated that the first aim of the school was to develop in teachers mental and moral power with "so much of physical culture as necessary to secure health and efficiency." Along with this "power" the school strove to impart the greatest possible knowledge of the principles and skill in the arts of the teacher's 
profession, and "the best selection of general knowledge attainable in the time which is at the command of the student," believing that the student would secure "infinitely greater lasting benefits" by aiming first for mental and moral power (Florida state Normal College Catalog, 1904, p. 11).

The catalog also explained that the Normal College was the only institution in the state devoted exclusively to the preparation of teachers for the schools of Florida. Its aim was "not merely to enable students to secure certificates, but to make of them good teachers" (1904 catalog, p. 9). The school perceived its function as two-fold, academic and professional, noting that although normal schools ideally did little academic work for its own sake, one of the most important functions of the Normal was "to set the norms or standards of popular instruction, for which the name 'normal' is applied." The writer concluded that "our chief aim is to afford every phase of professional instruction and training which is needful to prepare students for the best grade of public school teaching" (1904 Catalog, p. 10).

The normal school awarded only one degree, a "Licentiate of Instruction," or "L. I.," the usual normal school degree at the end of the century. W. T. Sheats, the Florida Superintendent of Instruction during most of the years the school operated, vehemently opposed 
the automatic certification of normal school graduates, stating that "when it comes to select the tutors and character builders of our children, let us test everything, even if it has a college stamp on it" (cited in Goulding, p. 33). The school was allowed to award its graduates with a First Grade County Certificate, which gave them the right to teach for three years before being required to take exams for continuing certification.

\section{The curriculum}

The proclaimed curriculum of an institution can be "extraordinarily revealing" about the values a society cherishes and wishes to impart to its children (Kliebard, 1992, p. xiv). The curriculum of normal schools was doubly so, because the academic work reflected the need to train teachers in the subjects which Americans most wanted their children to learn.

Americans in the late nineteenth century, no matter what region of the country they lived in, greatly respected "culture," the key term of an ideology that honored good manners, an acquaintance with literature, patriotism, ideals, spiritual values, and respect for the fine arts. Middle-class strivers suscribed to popular magazines, hung pictures in their homes of American literary figures, and attended entertainments, such as the Chautauquas, which adapted culture to "the needs of 
practical people" (Perry, p. 268). The curriculum of the Florida State Normal College reflected this aspiration toward gentility and culture. It also reflected other trends and realities in the United states, and in the South. Poorly educated students, the controversies over education which were taking place in research universities in the North, the need to educate students to take their places in a newly industrialized and expanding nation, changing legal requirements for teachers, and even the whims and personalities of legislators, superintendents of education, and principals all were mirrored in the courses which aspiring Florida teachers had to take.

National trends in education.

Educational theorists promoting radically differing ideas and ideals provoked controversy and conflict which permeated American education during the $1890 \mathrm{~s}$ and the first decades of the twentieth century. During most of the nineteenth century, the practice of American education had been dominated by the doctrine of "mental discipline," based on the conception of the mind as a muscle which could be strengthened by the study of certain subjects, particularly Latin, Greek and the classics. Drill, memorization, and recitation were believed to be especially beneficial for invigorating the 
faculties of reason, will, memory, and imagination. Nineteenth century educators believed that intellectual and moral discipline should be taught in the schools and that mental discipline was essential to achieving this goal.

As the century ended, a radically changing economy and society made the doctrine of mental discipline appear to be outmoded. Competing educational theorists advanced newer ideas for the most beneficial school curriculums. The Committee of Ten, headed by Harvard President Eliot, recommended a course of study which retained the classical curriculum. G. Stanley Hall's popular childstudy movement called for study of the developmental stages of a child's life. Hall argued that Eliot's curriculum, which retained subjects such as Latin, was useless for the "great army of incapables" flooding the new American high schools. He urged schools to adopt a curriculum based on the practical realities of the lives of these children.

William T. Harris, the United States Commissioner of Education, articulated a third approach to education. Harris advocated a humanistic curriculum, based on "the five windows of the soul" - grammar, literature and art, mathematics, geography, and history. The Herbartian movement, an entirely different approach, attracted many of the most active, dynamic educators of the day, 
including John Dewey (Kliebard, 1987, p. 5-18). The "Herbartians," as they called themselves, had radically new ideas based on the theories of Friedrich Froebel, a German educator.

Many Americans at the end of the nineteenth century expressed a sense of unease at the rapidity of the changes in society. Henry Adams wrote that the American landscape itself had become unrecognizable as "tall chimneys reeked smoke on every horizon...and dirty suburbs formed the setting of every town." The rise of scientism and rationality had undermined all the traditional certainties, and "the city had the air and movement of hysteria" and people were "irritable, nervous, querulous, unreasonable, and afraid" (Adams, p. 431, 462). Educators, politicians, and students of the new science of sociology sought a basis for the maintenance of order. Edward A. Ross wrote Social Control in 1901, positing that in the absence of religion, the schools had become society's best means of instilling social restraint in the young - especially in the children of blacks, immigrants, and the poor, all of whom were perceived as threatening to the social order (Kliebard, 1987, p. 87). This concern for social order affected the course of American education and the required studies in the Florida state Normal school. Albert G. Boyden, principal of the state Normal School in 
Bridgewater, Massachusetts explained the role of the normal schools in maintaining an ordered society:

Why have state normal schools? The answer is plain: Good public schools are essential to the well-being of the state. The public school brings the children and youth of the community into a larger social life than that of the family, and trains them to live with their fellows. It trains the children to obedience, truthfulness, industry, order, reverence for law, a just regard for the rights of others, to all the virtues of a good citizen, by leading them to live these virtues in their daily life. The public school is the most efficient agency for training to good citizenship, when it is what it should be (Boyden, in "Problems which confront the normal school," p. 1).

Frederick Winslow Taylor's efficiency movement, with its stress on order and regulation, was incorporated into American education as a means of instilling discipline and obedience in the young, so that they would fit smoothly into the new industrial order. As a corollary to the social efficiency movement, educators impressed by Russian manual training methods advocated a new type of education, which would "restore dignity to labor" and 
"train the hand" as well as the mind (Kliebard, 1987, p. 94, 131). The manual training movement would be incorporated in the curriculum of the normal school in 1904 .

Changing legal requirements for teachers.

For many years, Florida counties certified teachers, with little regard to their qualifications for teaching. When $W$. T. Sheats became superintendent of Public Instruction in 1893, he acted to take the examination of teachers out of the hands of local authorities, who, he believed, were incapable of examining candidates and were biased by "questions of necessity, relationship, politics, personal advantage, spite, or other influence." Sheats believed that too little distinction was made between different grades of teachers and that the disparity in requirements for the same grade of certificate was too great "in the few counties in which anything like examinations were held." At his urging, in 1893 the Florida legislature enacted the State Uniform Examination Law, requiring annual teacher examinations to be held twice a year. The state superintendent would write the examinations, and deliver them under seal to the county superintendents. The completed exams, identified only by number, would be graded by a committee selected from the county school board (Report of the 
Commissioner of Education, 1893-94, Vol. 2, p. 13701372 ).

Teachers taking the county examinations could receive a first, second, or third grade certificate, depending on how well they did on the exam. The examinations included orthography, reading, penmanship, arithmetic, English grammar, geography, United States history, physiology, composition, theory and practice of teaching, algebra, physical geography, bookkeeping and civil government. The new law provided for state certificates, issued after examination in ten additional subject areas: geometry, trigonometry, physics, botany, zoology, English literature, general history, mental science, rhetoric, and Latin. Teachers seeking a "state certificate," valid for five years, had to score an average grade of 85 percent on the exam and have twentyfour months experience teaching. A "primary life certificate," good for life, certified teachers with kindergarten or special primary training. A "life" certificate could be issued without examination to "eminently successful" teachers who had been especially endorsed (Report of the Commissioner of Education, 189394, Vol. 2, p. 1370-1372). The new Uniform Examination Law changed the curriculum and admission requirements of the normal school. 


\section{Student under-preparedness}

Students in institutions of higher education in Florida and all across the south were notoriously underprepared for college work. The third principal of the school, C. L. Hayes, wrote that the standard of admission to the normal school was low compared to other states, but it was as "high as conditions in Florida at present justify," which made a long course of study "imperative" (Biennial Report, 1898, p. 295-296). During the years the school operated, preparatory work was called by different names, but the school never could dispense with it. This problem was not unique to Florida. In 1891, Thomas G. Gray, president of the normal school of St. Cloud Minnesota, wrote that "could normal schools obtain a student body with adequate academic preparation they could at once devote all of their energies to their real function" (Gordy, p. 94). He concluded that "the work of the world must be done with such tools as the world has and the teaching of the world must be done with such men and women as the compensation offered for it can secure" (Gordy, p. 126). Without a comprehensive system of high schools, the normal schools, colleges, and universities in the South and elsewhere had to take students as they found them. 
Legislators, superintendents and principals

Finally, the curriculum of schools at all levels has always been determined in the end by individuals. The interests, aspirations, and quirks of legislators, school principals, and state superintendents directly influenced the course of study in the Florida state Normal School.

The first principal of the school, H. N. Felkel, was an astronomer as well as an educator. He lectured on astronomy at early Chautauqua meetings in DeFuniak before becoming principal of the new school (Pyburn, Chautauqua, p. 9). The curriculum during Felkel's tenure included very little pedagogical training, but required the graduating class to take astronomy, surveying, and navigation, the use for which may well have escaped his students.

Southern legislatures "wavered with the prevailing winds, subject to the dictates of a few powerful or persuasive men" and their actions were difficult to predict (Ayers, p. 43-44). Since the normal school charged no tuition and depended entirely on legislative appropriations, legislators had to be convinced of the worthiness of any proposed course of study or capital improvement. The legislatures sometimes changed the requirements for diplomas and certificates. In 1889, the state superintendent reported that the state Board of Education had called the attention of the county 
superintendents to the importance of instructing boys in the use and handling of tools, and girls in cooking, sewing, and other domestic accomplishments. However, few Florida teachers were trained to teach either manual arts or domestic science courses. The superintendent reported to the legislature that the problem had already been remedied, as such courses were "now taught in the mormal colleges" (Report of the Commissioner of Education, 188889 , p. 708 ).

Principal Felkel responded to the situation by inserting a lengthy description of a rather grand industrial department planned for the normal school.

\section{INDUSTRIAL DEPARTMENT}

It is now contemplated by the Board of Education to have industrial training made a part of the school work of the state by having established in each county at least one school devoted to such training, and to this end it is the purpose of the management to have the Normal Colleges prepare teachers to take charge of these particular schools. To do the work in view, this institution will be supplied with appliances for teaching telegraphy, type writing, shorthand, book-keeping (practically), printing, surveying (field work), plotting and mapping. This work in industrial training will 
constitute a post graduate course and only in particular cases will other students be allowed to enter this department. The course will cover one year, and upon its completion the graduate will be furnished a special certificate setting forth the fact that the holder is prepared to organize and manage any county industrial school in this state. For the ensuing year the school will be prepared to give instruction in all the branches of business enumerated above, and as soon as arrangements can be made appliances will be added for teaching toolcraft in wood and metal, and the management of ordinary machinery .

For the Industrial Course a tuition fee of ten dollars per quarter (ten weeks) will be charged. For any one of the branches named four dollars per quarter (ten weeks) will be charged. Shorthand and typing will be counted as one branch. (Catalog, 1890, p. 13)

This proposal was never implemented, probably because of legislative reluctance to invest in the building and equipment Felkel envisioned.

Principal Felkel left DeFuniak in 1893 to head the new school for the Deaf and Blind at st. Augustine, and was replaced by the Reverend $C$. P. Walker. Reverend 
Walker had to drastically revise the course of studies after the state instituted the new requirements for teacher certification in 1893. The school had offered a three year course. One year was entirely preparatory, and the actual normal course took two years to complete. The new four-year course was composed of grades D, C, B, and A ("Class A" was the graduating class). The 1893 Catalog said that although diplomas were no longer of "practical benefit under the provision of the last legislative enactments - which, by the way, we regard as the most wholesome that could have been passed, still we are determined by faithful, thorough work, to force a recognition of the merits of our diplomas upon the educational public" (Catalog, 1893, p. 20). Walker, a minister, added Bible study to every year of the curriculum, explaining,

The formation and development of Christian character constitute one of the essential features of a Normal school. The Bible is therefore introduced into the school as a text book, and the first and freshest hours of the day are daily devoted to its study and to an insistence upon the necessity of a practical application of its precepts. No man, no woman should presume to lead, to mould the child mind without the light of God's 
word shining, not only from precept, but from example (Catalog, 1893, p. 21).

The Course of Study

The new course of study described in detail in the 1898 catalog indicated how hard the small faculty at the normal school was expected to work.

\section{Class D}

Fall Mr. Hayes - Pedagogy

Mr. Cawthon - Geography, Arithmetic

Mr. Bennett - Reading (Literature)

Mrs. Reeves - Language, Orthography

spring

Mr. Hayes - Methods and Management

Mr. Cawthon - Arithmetic, Physiology, Orthography

Mr. Bennett - Reading (Literature), Penmanship

Mrs. Reeves - Language, United States History

Class C

Fall Mr, Hayes - Psychology, Literature

Mr. Cawthon - Physical Geography, Latin

Mr. Bennett - Arithmetic, Algebra

Mrs. Reeves - Grammar

Spring

Mr. Hayes - Psychology, Methods, etc., Literature

Mr. Cawthon - Latin, Civil Government

Mr. Bennett - Arithmetic, Algebra 
Mrs. Reeves - Grammar

Class B

Fa 11

Mr. Hayes - Applied Psychology, Literature

Mr. Cawthon - Civics, Physics

Mr. Bennett - Algebra, Latin

Mrs. Reeves - Rhetoric, English history

Spring

Mr. Hayes - School Management

Mr. Cawthon - Physics

Mrs. Bennett - Geometry, Latin

Mrs. Reeves - Rhetoric, Botany

Class A

Fall Mr. Hayes - History of Education

Mr. Cawthon - Zoology, Chemistry

Mr. Bennett - Geometry, Latin

Mrs. Reeves - General History, Literature

Spring

Mr. Hayes - Practice Teaching, etc.

Mr. Cawthon - Chemistry

Mr. Bennett - Trigonometry, Latin

Mrs. Reeves - General History, Literature

The 1898 catalog explained the purpose for every course as well as the methods by which each one would be taught. The nineteenth century reverence for culture was 
reflected in the catalog's discussion of the reading and literature courses, which stated that the purpose of these courses was not to make "elocutionists, but readers... real readers of books...literary men and women." Students would become "educators of the true scholarly type" whose contact with the "great fountainhead of human thought," great books, would "inspire broader, larger, nobler lives in themselves and in the youth of Florida whom they are to direct in the paths of thought" (Catalog, 1898, p. 28).

students would not only read great works of literature, but would store up "memory gems" to strengthen their mental faculties as well as to supply them with cultured thoughts and quotes to be used in the classroom and in their lives.

Nineteenth century educators and policy makers were very concerned with health and hygiene. Reformers believed that the schools were the ideal vehicle through which to improve public health. Other progressive reformers, particularly in the South, believed that temperance was the one best solution to the social evils of the times. These different agendas for reform were combined in the required course in physiology. The study of anatomy and physiology would help students to learn and understand the principles of "personal and public Hygiene." The course stressed that students could "do 
much for the happiness and well being of those entrusted to their care by judicious and truthful presentation of the laws of health," particularly habits of study, sleep, exercise, diet, cleanliness, and dress. Reflecting the temperance mood of the times, the course gave special consideration to alcoholic beverages and narcotics "that students may fully understand their dangerous cumulative effects, even when use in moderate quantities as beverage or medicine" (Catalog, 1898, p. 33).

Educators continued to believe in the value of training the faculties of the mind. In the Latin course "those methods of teaching are followed which, it is thought, will best enable the student to acquire the greatest practical benefit both in the preparation for teaching the subject ....and, at the same time, the best possible mental training, a chief value of Latin" (Catalog, 1898, p. 29). The Chemistry course encouraged the "concentration of thought and energy," while the course in civil government afforded "valuable mental discipline," as well as stimulating patriotism and awakening in students "a sense of the responsibility which will devolve upon them as the citizens of a mighty nation" (Catalog, p. 34, 30).

The pedagogical courses reflected the new efficiency movement and the emphasis on scientific pedagogy. classes on method, management, school economy and 
education history emphasized both the "theoretical and the practical" aspects of education. The objective of teacher training was to instill in the students "the true spirit of the teacher." Students would study the laws of mental growth and their application, as well as important educational systems of the past and the preparation and presentation of appropriate practice drill (Catalog, 1898, p. 36).

These classes required daily recitations, throughout the year (Catalog, 1898, p. 37). Principal Hayes wrote in the 1898 report to the Florida superintendent of Instruction that he wished to call attention to the fact that the instruction in Pedagogy, or the Theory and Practice of Teaching, was "as thoroughly and systematically pursued by the students" as the rest of the curriculum, and that every student in the school pursued the full course, both literary and professional (Biennial Report, 1896-1898, p. 296).

The legislature enacted another series of laws in 1903 establishing a statewide system of high school instruction. The DeFuniak school reorganized its curriculum for a last time, incorporating the new legislative requirements as well as new programs, such as manual training and a Froebelian kindergarten program based on the latest ideas. Recitations and mental discipline still remained an important part of the 
program of studies.

Although Florida's expanding system of high schools led educators to hope that preparatory programs in institutions of higher education could soon be ended, the reorganized school still included what was now called a "Sub-normal" department to prepare students for work in a four year normal course. The redesigned course of studies was much more rigorous and professionalized than the earlier programs offered at the school. The normal school expanded its programs, offering a two year training program for kindergarten teachers, a comprehensive manual training program, graduate courses for a few students, and a one year "Professional Training Course" for teachers holding a First Grade county certificate.

Anna Chaires directed the new kindergarten training program. Miss Chaires, a native of Tallahassee, studied at Columbia's Teacher's College and the Froebel Training School and worked as principal of the Carnegie Hall Kindergarten in New York before being hired by the normal school for $\$ 600.00$ a year in 1903 (Hammond, 1957, p. 122). The kindergarten department was new to Florida, and was unique in the South. Miss Chaires educated teachers in the modern ideas and theories about the development of the child which she had studied in New York. State Superintendent Sheats strongly supported the 
new kindergarten movement for Florida because school terms in Florida continued to be much shorter than in other regions of the country, and because Florida's children, like other southern children, left school at young ages (Hammond, 1954, p. 46). The new kindergarten department proudly described in the catalog replicated the latest Froebelian methods, which were being promoted around the United States by up-to-the-minute educators such as John Dewey.

The Kindergarten occupied a large airy room, and all the equipment was of the best quality, for "none is too good for these little ones." A piano, pictures, and all the requisite furniture were supplied, and twenty-five children from four to six years of age enrolled in the program.

The Kindergarten Training Class observed methods during their first year and did practice work in the model kindergarten during the second year. Normal school pupils in the regular program benefited from the observation and study of Froebel's method of teaching and governing young children.

Miss Chaires explained that the aim of kindergarten training was to "gain free self-acting development from within, to strengthen the student's three-fold nature, and to add new purpose and understanding to life... This course is full of delightful surprises to one who loves 
children, is sympathetic and imaginative. She must be willing to undertake self-discipline as well as child training." Miss Chaires required that students have academic preparation equivalent to that required for a First Grade Certificate, and preferred high school graduates with "natural ability, good health, a happy disposition, a good voice, and some skill in playing the piano."

Aside from the work included in the curriculum, students learned to select and order kindergarten materials, and to handle all the bookkeeping and other practical details necessary to organize and conduct a kindergarten. Students learned songs, stories, and methods of using the "gifts and occupations" which were unique to Froebelian kindergartens, which stressed student-directed learning and discovery. "Gifts" were generally geometric objects which could be manipulated by small children in order to discover spatial concepts and solve problems. "Occupations" were materials such as sand or clay which could be shaped, allowing children to develop creativity and manual dexterity while learning independently. The kindergarten teacher carefully structured the work done with gifts and occupations to maximize independent learning (Catalog, 1904, p. 40-42).

The reorganized normal school curriculum included the study of psychology. By 1900, the mind itself had 
become the subject of study in American research universities, and Americans no longer agreed on the meanings of reason, thought, and mental function. These verities had been replaced by the conflicting theories of researchers and theorists at the new university psychology labs (Perry, p. 306). The normal school attempted to synthesize these differing approaches in the three required terms of psychology. The first two were "devoted to a general study of mind through its phenomena avoiding ontological speculations on the one hand, and the dilution called 'educational psychology' on the other. The nature and scope of experimental 'laboratory psychology' are noted, but the field is, in the main, left to the specialist at work in it." During the third term, students studied the genetic aspects of human psychology and, as the faculty believed that the best examples were found in "flesh and blood," students analyzed "concrete examples of psychic processes from the fields of their own consciousness." They studied "excellent books in the library from such standard authors as Wundt, Sully, Ladd, and James" (Catalog, 1904, p. 19).

The principal, Mr. H. E. Bennett, taught the pedagogical courses, which included several terms of "The Art of Teaching," as well as "History of Education," "School Management," "School Laws and Organization," 
"Primary Methods," "Educational Theories," and observation and practice teaching. Mr. Bennett stressed that his classes emphasized the latest theories and practices (Catalog, 1904, p. 19-20).

The normal school now had a model school, and students practiced extensively under the direction of the principal, Mrs. S. D. Cawthon, herself a member of the first class to graduate from the normal school in 1889 . Practice teaching was a most important part of the program. The model school had three grades, and normal school students in the last years of the program taught at least two hours a week in the model school. Principal Bennett explained that educational theory had little meaning until the teacher translated it into terms of child life, for "one who has studied educational problems only in their theoretic abstractions finds in the actual processes of teaching problems which are new to him, and which are well-nigh insuperable until he has found the connection between real teaching and the written accounts of it." Bennett concluded that "many a teacher has no professional mirror in which he can see himself as he appears to others. He grows in his errors or peculiarities until he wonders why he is rejected by Boards and Superintendents. He finds himself a failure with no knowledge of the reason." Normal school graduates could avoid this horrifying possibility, 
because the practice school would disclose these tendencies to the trained eye of Mrs. Cawthon, who would "frankly and truly explain" them before they became ruinous habits. As the "critic teacher" she held weekly conferences with students to discuss typical mistakes and weaknesses for the benefit of the entire class. This training would also prepare students for critical observation by school principals and superintendents.

Mrs. Cawthon herself taught model classes twice a week at the Practice School to illustrate the application of the class work in pedagogy by model lessons. Mrs. Winnie McEwen, a student in the model school, remembered that her family was very pleased with the modern, clean little school (McEwen, taped interview). A photograph of Mrs. Cawthon and the children taken in 1900 showed little girls in pinafores and boys in short pants with their teacher, dressed in white and looking much like the Gibson Girl, standing in front of a white frame schoolhouse (Brochure, 1900). The littlest students of the normal school had a very full schedule as described by the catalog:

1. Plays and games - Free play, rhythmical and imitation plays; sense games; dramatizing and acting of songs, stories and trades.

2. Stories - Tales, fairy stories, myths, rhymes, 
and poems.

3. Music - Seasonal songs and music based upon the children's interests and emotional experiences.

4. Festivals - Celebration of Thanksgiving, Christmas, birthdays of children and of distinguished persons.

5. Morning exercises - Daily participation in an exercise of the entire school.

6. Handwork - Simple articles in paper, cloth, clay, grass, etc.

7. Gardening - Chief outdoor occupation during fall and spring term.

8. Painting and drawing - Illustrations using pencil, crayon, brush and scissors.

9. Excursions - To blacksmith's, shoemaker's, market, park, turpentine still, etc.

10. Housekeeping - Care of school room, of materials, of plants and animals, of their own wraps, books, etc.

11. Nature study and Science - study of plants and trees. Simple laboratory work.

12. Reading, writing, spelling - These subjects are not taught independently, but in connection with others - such as history, geography, science and Iiterature.

13. Mathematics - Correlated with science, history, 
geography, handwork, etc.

14. Morals and manners - Developed in simple but effective manner from nearly all games, stories, exercises, etc. (Catalog, 1904, p. 20-23).

Mrs. Cawthon never failed to emphasize to her future teachers that they must be the "masters" of conditions in the schools instead of submitting to them and making them the excuse for poor results.

The normal school continued to require extensive work in the "common branches" of math, geography, history, orthography and science as well as language and literature. Students studied history so that in their own classrooms they could inculcate the spirit of patriotism, and a love for the right, by studying the lives of Americans who had "made our country's history glorious," and especially by "showing how, in history, right inevitably ends in good, and wrong as a necessary result brings suffering and unhappiness" (Catalog, 1904, p. 30). Once enrolled in the regular normal course, students were also required to take four full years of Latin, including the study of the writings of Caesar, Ovid, and Cicero.

Finally, the school opened the long sought manual training department. Many southern educators believed that the future of the south depended on industrial 
education as an agency for economic development (Thach, p. 92). Florida superintendent sheats enthusiastically advocated a manual training program for the normal school, urging the legislature to approve it, for "if the South is ever to become influential through wealth... the elements of many industries [must] be taught" (Biennial Report, 1900-02, p. 434).

Beginning in 1904, the school required students to take four years of manual training, under the direction of Miss Rindell. The manual training course was to be an agency of reform and progress. Manual training would teach the normal students, and their future pupils, to appreciate the utility of "the unlimited native resources going to waste about them, especially that most costly of all wasted resources, unused time and energy." The school hoped to introduce through its students "useful, attractive, and educative occupation into many uninviting homes and unprofitable lives." Students learned to make "countless little things of use and beauty," such as spring hats made from a twenty-five cent hat frame and five cents worth of raffia. Miss Rindell's classes paid special attention to the use of wasted native resources, such as wire grass, pine straw, palmetto, and corn shucks (Catalog, 1904, p. 36).

Principal Bennett observed that the "department in its first year had many obstacles to overcome" (Catalog, 
1904, p. 36). For one thing, the first year of manual training was a near disaster for the seniors. Of six students due to graduate in 1905, five failed manual training. After a lengthy meeting with the faculty, Principal Bennett decided that as manual training had not been in the catalog when these students matriculated at the normal school, and that "it would be a serious reflection on the management of the school if five-sixths of a class should be refused graduation," he would allow the entire class to graduate (Minutes). They were the last graduates of the Florida state Normal College.

\section{The Student Day}

In 1893, students began their days at $5: 30$ in the morning. After lessons for the day finished, they were required to remain in their rooms studying between four and six p. m., unless prevented by unavoidable circumstances. They retired promptly at 10:30 p.m., and rose again the next day to devote the morning hours until breakfast to general exercise or reading, followed by devotions and Bible study, and then classes (Catalog, 1893, p. 8).

Ten years later, the daily schedule began with the rising bell at 6:30 A. M., followed by breakfast at 7:00. Recitations began at $8: 00$ and chapel, which all students were required to attend, was at $8: 45$. Dinner was served 
at 1:10, followed by more hours of class and supper at six. Students in the dorms could then enjoy an aftersupper social hour until 7:15. Many attended a short vesper service at this time. Quiet study time in the evenings was followed by the "retiring hour" at 10:00 (Catalog, 1904, p.51-52). Acting on the suggestion from the faculty that the students were overworked, Principal Bennett agreed that twenty hours of class work per week should be the maximum, and that classes in Physical Culture should meet only once a week (Minutes, March 8, 1904). Students could go out on Friday nights, and had time off from Saturday afternoon until Tuesday morning in order to study, attend church, and take care of personal shopping .

The college employed black cooks (Census). Students, the principal and his family, and perhaps other faculty ate "family style" at the table, saying grace before meals. The large meal of the day was midday dinner. Market prices published in the 1888 Weekly Critic and grocery ads in the Normal Messenger indicate that the residents and students in DeFuniak springs ate typical southern fare. They drank coffee with their meals. Bacon, ham, grits, and eggs were on the breakfast table. Magnolia hams, chicken, pork chops, biscuits, pole beans, blackeyed peas, greens, and tomatoes would have been served at dinner, followed by a buttermilk or berry pie. 
On Sundays, ice could be purchased in town for homemade ice cream. Fresh oysters from Mobile Bay and Apalachicola were available in town, and the Gulf of Mexico only fourteen miles away was an abundant source of seafood. 
Classroom buildings at the Florida State Normal School

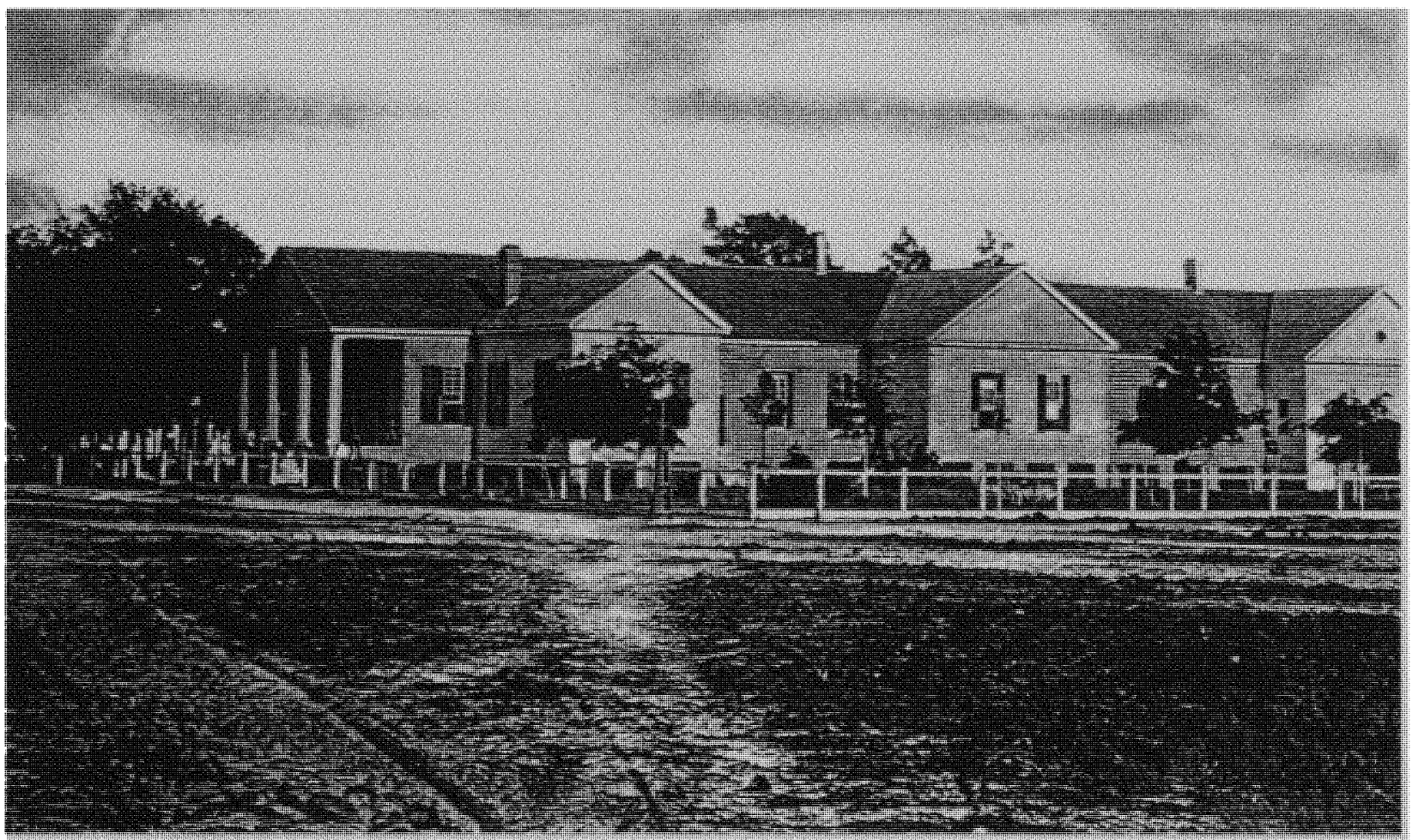


Cost of attendance

The Florida state Normal School never charged any tuition to residents of Florida, and out-of-state students paid a modest $\$ 5.00$ a term.

Boarding costs both in the dormitories or in private boarding houses that took in students were also modest, never exceeding, according to the catalogs, $\$ 2.50$ to $\$ 3.00$ a week. The 1890 catalog reported that a few young men and ladies had rented furnished rooms and boarded themselves for only six dollars a month (Catalog, 1890, p. 11).

In 1898, Principal Hayes wrote that the cost of attending the normal school was low, not because of inferior "talent employed" or school equipment, but because the location was favorable for "cheap living," and the state maintained the school. Hayes estimated expenses for a school year of eight months as:

Board $\$ 80$ to 96

Washing $\$ 8$ to 12

Books $\$ 5$ to 15

Total $\$ 93$ to 123

The cost of board included fuel and lights, and the school charged no fees at all to students (Catalog, 1890, p. 23).

Hayes wrote an essay on the value of a normal school 
education entitled "Invest in Yourself," published in the State Normal Messenger, a quarterly publication the school circulated to graduates and county superintendents.

\section{Invest in Yourself}

Fellow Teacher:

The writer knows from experience how precious that little sum of money is which you, by rigid economy and patient labor, have saved out of your meagre salary as a teacher. He knows too that you are wondering how to spend it to the best advantage. Had you thought of investing it in self? If there is that "outcome" in you which there should be in a young, inexperienced, poorly qualified but honest, perservering, ambitious teacher neither pigs nor calves nor sheep nor cattle nor lands nor bonds nor anything else in the material markets of the world will equal yourself as an object of investment. Indeed what is money spent for education of yourself by yourself but an investment in yourself? And what dividends! A few hundred dollars thus spent are sufficient to yield perpetual income in the form of increased earnings, and, moreover, great returns in personal influence for good. At least a thousand instances 
could be cited from well known biography - had you thought of trying it? If you have, consider well the exceptional opportunity which is afforded to you who desire to be teachers. The state gives you entirely free tuition at the state Normal School, (worth at least $\$ 40$ a year) provided you pay only your living and traveling expense (Hayes, Normal Messenger, May 1899, p. 5:1).

In 1900, the school brochure advertised expenses for an eleven week term (there were now three terms in the school year) as:

$\begin{array}{ll}\text { Board } & \$ 27.50 \\ \text { Washing } & \$ 2.75 \text { to } 4.00 \\ \text { Books } & \$ 2.50 \text { to } 5.00 \\ \text { Total } & \$ 32.75 \text { to } \$ 36.00\end{array}$

This was described as an ample allowance for living as a student in DeFuniak springs.

In 1902, the catalog reported, under the heading "Still Cheaper Living" that some "heroic students," both young men and young women, had rented rooms and "kept house" at a trifling cost. For instance, three young ladies rented furnished rooms from a respectable family one year and lived "comfortably" on only $\$ 1.25$ each per week for rent, fuel, food and light. The catalog said that several instances of such economical living could be 
cited, but that "we recommend this plan only to such as cannot come and pay regular board." In 1904, student expenses for an eight month term were still unchanged from the cost in 1890:

$\begin{array}{ll}\text { Board } & \$ 80.00 \\ \text { Books } & \$ 7.00 \\ \text { Laundry } & \$ 8.00 \\ \text { Total } & \$ 95.00\end{array}$

The catalog claimed that students could live more cheaply at the normal school than they could if they remained at home, and that many students earned enough by teaching four months during the summer to keep themselves during the rest of the year at the Normal School. They were "in this way rapidly advancing to the front of their profession without financial aid from any source" (Catalog, 1904, p. 49).

The Louisville and Nashville as well as the Florida Central and Peninsular Railroads did their part to help future teachers defray expenses. For ten years, the railroads offered students of the normal school free transportation home when the students presented certificates showing that they had paid full fare to DeFuniak Springs (Biennial Report, 1894-96, p. 111). By 1898 the offer was slightly less generous. The trains offered students round trip tickets for one and onefourth of the regular fare, which they continued to do 
until the school closed in 1905 (Catalog, 1898, p. 22 and 1904, p. 49).

Still, the expense of attending school was a problem for many teachers in the Florida of the 1890s. Hayes had not exaggerated when he described their salaries as "meagre." The mean salary for white women teachers in 1893 was $\$ 49.67$ a month. If the teacher was unfortunate enough to work in Calhoun County, she was likely to earn only $\$ 25.00$ a month (Biennial Report, 1892-94, p. 232233). In 1897, after the terrible freeze of 1895, the mean salary for white female teachers in Florida had declined to $\$ 33.53$ a month. That year, the lowest salaries for white women teachers were paid in Wakulla County, where the mean was $\$ 19.00$ a month (Biennial Report, 1896-98, p. 111). Many counties only supported schools for four months of the year. Nationally, at least a third of the women teaching in 1900 were entirely self-supporting. Even if a young woman lived with her family and taught in the 1890s, savings for expenses of only $\$ 100.00$ a year to attend the normal school must have been almost impossible to accumulate.

This greatly concerned the administrators of the school. Principal Walker wrote in 1895 that in spite of his efforts to inform county superintendents of the minimal cost of attendance at the normal school, he believed that many teachers were unaware that tuition was 
free to Floridians (Biennial Report, 1894-1896, p. 112). He also stated that few students stayed to graduate because they left the school as soon as they were able to secure a First Grade county certificate, and that the students attending the school primarily came from "that class whose expenses are to be paid by the results of their own hard toil." Walker complained that the present system of certification offered students no inducement to take the complete course, "other than their own ambition and desire for higher scholarship" (Biennial Report 1894-96, p. 113).

In 1897, Principal Hayes recommended to Superintendent sheats that the state provide for one continuous free scholarship for each county, allowing students to attend the normal school for two years, saying, "I believe it would be wise and, all things considered, economical for the state to establish one continuous free scholarship for each county...sufficient to pay the actual cost of transportation from the student's home to DeFuniak springs and return once each year and board while at the school" (Biennial Report, 1896-98, p. 299-300). Superintendent Sheats supported the idea, and told the legislature in both 1899 and 1901 that, as the state had provided scholarships to the Military Institute, "it was not an unreasonable request that the teachers be put on an equal footing with the 
soldiers" (Biennial Report, 1900-1902, p. 432).

In 1901, the legislature allotted funds for county scholarships to the state normal school. The Scholarship Act stated that the greatest educational need of the State was more professionally trained teachers, and investment in teachers would "yield the greatest possible returns." Florida had funded county scholarships for young men to the military school at Bartow at an annual cost of $\$ 200$ each, "while no such privilege is extended which is available for young women of the state, though a large majority of the teachers of the state are women, and would gladly improve opportunities of better preparing themselves for this profession if like advantages of free board were offered them." The legislature approved an annual sum of forty-five hundred dollars to establish and maintain one scholarship for each county in the state Normal School at DeFuniak. Springs .

The normal school awarded scholarships on the basis of competitive examinations in each county to a young man or woman, between the ages of eighteen and twenty-five, "of good moral character and competent to meet the entrance requirements prescribed for said normal school" who proposed to make teaching a profession. Each scholarship student received $\$ 12.50$ a month, a total of $\$ 100.00$ a school year, for board and other expenses 
during the school term.

The scholarships were good for two years. Recipients had to demonstrate "adaptability for teaching" and sign an agreement to teach for at least four years in the state or to refund the money received. If a county failed to award a scholarship, the principal could arrange for a student from another county to obtain a scholarship by proxy.

The normal school published information about the scholarship for distribution throughout the state. Notices advertising the examinations were posted in the "newspaper having the largest circulation in the county," or in "five conspicuous places in different parts of the county" for at least two weeks prior to the exam. The uniform statewide exams were held under strict conditions. Exam questions were delivered to county superintendents under seal, opened by the applicant, and graded by the county superintendent and school board. Questions included all the subjects, except for pedagogy, required for a teacher's third grade certificate.

Persons whose known habits, or physical or moral defects would "incapacitate or interfere with them becoming successful teachers" were not allowed to take the exam. Any scholarship student entering after the beginning or leaving before the close of a school month, or who was "irregular in attendance without sufficient 
excuse," was paid the scholarship allowance only for the portion of the month that he or she attended school. Scholarships could be cancelled by the state Board of Education for irregular attendance, deficiency in school work, or for "other sufficient reasons."

The text of both the Act to Establish Scholarships and the Regulations pertaining to the scholarships were circulated throughout the state, to be posted in prominent places and county superintendent's offices in full view of the public (Register of the Florida state Normal College).

Principal Hayes, wishing to encourage those teachers who did not receive a scholarship, wrote, "To those who make our entrance requirements, but are excelled by some one else, our advice would be, 'Come, anyway, it will cost you but little. Perhaps you can secure a scholarship before you graduate'" (Catalog, 1902, p. 9). Forty-five scholarships a year were awarded beginning in the fall of 1901. Students signed monthly for their $\$ 12.50$ stipends. The faculty conscientously monitored the students's attendance and performance. Before receiving their scholarship money, all the receipients signed a "Pledge of Scholarship students" which read:

Each of the undersigned, in consideration of the 
benefits accruing from a Free scholarship in the Florida State Normal School, hereby agrees and pledges himself or herself to teach in the Public Schools of the state, health permitting, for at least four of the six years next succeeding the expiration of the Scholarship, or to refund to the State the money received from the scholarship (Minutes, May 1901).

The normal school awarded scholarships beginning in the year 1901. That year, 29 women and 16 men received scholarships. In 1902, 17 women and 11 men returned to use the second year of their scholarship. To make use of the remaining scholarship funds for 1902, 15 women and 11 men already enrolled were given assistance for a year, and two women were awarded a full two year scholarship. In 1903, 43 two year scholarships were awarded to 26 women and 19 men. In 1904, 25 of those students returned to complete the second year, and 20 students received assistance for a year.

A total of 55 students, 32 of them women, completed a two year program with the assistance of the county scholarships, and an additional 70 students, 36 of them women, received assistance for a year. A total of 68 women and 57 men received scholarships between 1901 and the closing of the school in 1905 (Register). 


\section{Living arrangements}

Living arrangements have been one of the most important and memorable aspects of the undergraduate experience for centuries (Lucas, p. 65). In the United States, clean and safe on-campus housing for students was rare at the end of the nineteenth century. Frequent violent outbursts characterized men's residence halls before the civil war. As a result, many college administrators such as president Eliot at Harvard disliked dormitories and argued that colleges should not assume the function and responsibility of feeding and housing students. It was not until 1896 that some of the larger midwestern universities began to build dormitories (Rudolph, p. 99-100). Boarding houses in college towns housed vast numbers of college students, as well as provided an income for widows, well into the twentieth century.

The first women college students lived at home or had to make living arrangements at approved boarding houses. Women at the University of Michigan, and other coeducational universities, even lived in mixed boardinghouses with male students (Horowitz, p. 194-95). Women at the University of California had a choice of living at home or in a boarding-house, and Radcliffe did not build its first dormitory until 1901. Only the most expensive northeastern women's colleges were entirely residential 
(Solomon, p. 97).

Even in the ante-bellum South, students at the smaller female seminaries boarded with local families for about eight dollars a month (Farnham, p. 121). In the ideal southern female college, however, the president or principal and his family had quarters on the first floor of a two to four-story building. Students and unmarried female faculty members had small bedrooms on the upper floors (Farnham, p. 105).

When it first opened in 1887, the Florida state Normal School held classes in a building lent to the school by the chautauqua. The first class consisted mostly of local students, and the few who came from out of town may have boarded with relatives or in boarding houses.

In 1889, a local gentleman, Mr. A. R. Jones, donated a five-acre piece of land to the school, which included a building used as a dormitory. Superintendent Russell said the building was a "very commodious and well-adapted dormitory in which students can obtain board at a very low rate under the best regulations and moral influence." The building was next door to the president's residence, and he personally supervised the students living in it (Biennial Report, 1888-1890, p. 5). Students in the dormitory paid $\$ 2.50$ to $\$ 3.00$ a week for board. They came prepared for dorm life with sheets, pillow-cases, 
towels and one pair of blankets (Catalog, p. 1889).

The dormitory building, which had been described as "commodious" in 1889, apparently deteriorated quickly. In 1893, Principal Walker wrote to Superintendent sheats:

Accomodations for boarding and lodging are very inferior. So uncomfortable in fact that students do not like to stay in the Dormitories. I receive letters frequently from south Florida making inquiry about the boarding departments, and expressing willingness to attend, if the students are found board in the Dormitories. I consider the building for young ladies as unsafe in stormy weather. It is an old structure without blinds, and with nothing to break the monotony of bare walls and rough floors. There are at present only six young ladies boarding in it and they would not live in it if they had other quarters. Most of the boarding students are in private families. I must say that the inferior accomodations furnished by the state militate against the success of the school. We have in attendance now (Jan. 22, 1895) 117 pupils and many others to come in the first of February. We shall be forced to deny their admission on account of lack of room. The larger portion are boarding pupils, twenty counties are 
benefits accruing from a Free scholarship in the Florida State Normal School, hereby agrees and pledges himself or herself to teach in the Public Schools of the State, health permitting, for at least four of the six years next succeeding the expiration of the Scholarship, or to refund to the State the money received from the Scholarship (Minutes, May 1901).

The normal school awarded scholarships beginning in the year 1901. That year, 29 women and 16 men received scholarships. In 1902, 17 women and 11 men returned to use the second year of their scholarship. To make use of the remaining scholarship funds for 1902, 15 women and 11 men already enrolled were given assistance for a year, and two women were awarded a full two year scholarship.

In 1903,43 two year scholarships were awarded to 26 women and 19 men. In 1904, 25 of those students returned to complete the second year, and 20 students received assistance for a year.

A total of 55 students, 32 of them women, completed a two year program with the assistance of the county scholarships, and an additional 70 students, 36 of them women, received assistance for a year. A total of 68 women and 57 men received scholarships between 1901 and the closing of the school in 1905 (Register). 
there, supervised the residents. The catalog described dorm life as pleasant, Christian, and home-like. Everything in the new building was "neat and new... and the accomodation quite as good as necessary for health and comfort" (1898 catalog, p. 22).

By 1900, matrons had joined the faculty to supervise the dormitories (Brochure, 1900, p. 1). The school still permitted students to board in town, but in 1897 began to insist on regulating boarding houses. Students were no longer allowed to stay in any boarding house which accepted transient boarders (Minutes, Nov. 8, 1897). In 1901, the faculty was forced to allow a few women to board with a Mrs. Gillis, who apparently accomodated "transients," so the women's dormitories had filled up quickly (Minutes, Nov. 11 and Nov. 21, 1901).

The young men on campus continued to live in much more modest housing. In 1901, superintendent sheats said that a new dormitory for young men was "imperatively necessary" (Biennial Report, 1900-02, p. 166). Money had been allotted in 1901 to add twelve rooms to the men's dorm, but because of the condition of the building, it was instead spent adding a third floor with twelve more rooms and new furniture to the women's building. In 1904, the women's dormitory was a "good, new, three-story building of thirty-seven rooms besides parlors, diningroom, kitchen, storeroom and bath rooms. The sleeping 
rooms are pleasant and of good size, fitted with new iron beds, springs, mattresses, bureaus, washstands, chairs, tables, and wash-stand sets" (Catalog, 1904, p.8).

In 1901, the school installed a new water system on campus (Catalog, 1902, p. 29). Now, in the women's dormitory, "water was convenient on every floor for room use and fire protection" and bathrooms had been outfitted with porcelain tubs with hot and cold water (Catalog, 1904 p.8).

Until these improvements were carried out, students in both dormitories had to carry out housekeeping jobs. In the women's dorm, students boarding at the $\$ 2.50$ a week rate had to keep their own rooms in order, carry in their water, set slops out in the hall before school hours, and clean, but not fill, their lamps. The matron had wood brought in, the lamps filled, ashes removed and slops carried away. For fifty cents more a week, the women could have their water carried in and slops carried out by a maid (Catalog, 1902, p. 28). The young ladies had to bring a number of items from home including two sheets, one pillow, two pillow-cases, four towels, two blankets or quilts, and any other bed clothing desired, six table napkins, toilet soap, tooth-brush, a tooth-mug, comb and brush, and one teaspoon and one glass for use in the room. The matron furnished fuel and light (Catalog, 1898, p. 22). 
The best that could be said about the young men's dormitory was that it was "Christian" and had two stories, with thirteen large rooms and broad verandahs (Catalog, 1904, p.8). The young men had more choice in their boarding arrangements. They could arrange for full board, lodging, fuel and light for $\$ 2.50$ a week, table board alone for $\$ 2$ per week, or room, fuel and light alone for 75 cents a week in December, January, February and March, and 50 cents a week during the rest of the year (Catalog, 1902, p. 28). The men had more chores to do than the women. They had to bring in their own wood and water, remove their slops, have their bed-linen washed and kindle their own fires, or pay extra for this service. The matron removed ashes, and had fuel and kindling kept ready in the shed (Catalog, 1902, p. 28). Even though water was not handy, the danger of fire in the men's housing may have been reduced a bit when the school installed acetylene gas for reading lamps throughout the school.

Students living in the dormitories had rules to follow.

The young ladies had to agree to a number of regulations:

(1) that when they go out in town or elsewhere during the day that they shall return before night; 
(2) that they shall not go out driving with young men;

(3) that they shall receive calls from young men only at stated times;

(4) that they shall not absent themselves from the dormitory at night without permission, reasonable provisions being made for them to attend night services or entertainments.

Both men and women residents had to observe study hours and attend the church of their choice each sunday morning unless prevented by illness or bad weather. The Reverend walker believed that a "lazy, languid, idle habit of spending the Lord's day is not conducive to good manners or to good morals" (Catalog, 1893, p. 21). Other principals concurred, and regular church attendance remained a requirement (Catalog, 1902, p. 27-28).

In 1904, the administration added new regulations. Students were responsible for breakage and damage to furniture, crockery, glass or any other dormitory property and had to pay for it. They could not invite guests to meals, or to stay with them in their rooms without special permission from the supervisor, and had to pay 25 cents for guests's meals. If a student wished to dine in his or her room the rates were 25 cents for dinner (the large noon meal) and 15 cents for breakfast 
and supper. Board had to be paid strictly in advance and was charged from the day a student entered the dormitory until the last day of the commencement exercises. students had to be prompt at meal time, and to observe study hours.

Elsewhere, students at the Florida Normal school and Business College at White Springs, Florida, a private school which closed when its owner died, lived in rooming houses. The principal wrote that upon arriving in town, students should "leave your baggage at the depot and come to the President's office. He will see that suitable accomodations are found" (Florida Normal School Catalog, p. 28). Women students attending the East Florida Seminary in Gainesville in 1903 lived in a two-story wooden house. Their rooms were furnished with a table, chairs, bedstead, mattress, and washstand. The dormitory building had two bathrooms with hot and cold water, and the superintendent of the seminary promised to "give his personal attention to the supervision of the girls dormitory....Parents can send their daughters to the East Florida Seminary with the assurance they will be well cared for and carefully looked after" (East Florida Seminary, Catalog, p. 47). While the men at the Florida Agricultural College in Lake City lived in barracks, the catalog of 1897 reported that the state had not yet made an appropriation for a women's dormitory, and that young 
ladies would be required to board at selected boarding places. Parents were urged to correspond with the college president before their daughters left home (Florida Agricultural College, Catalog, 1897).

The Florida State Normal School was similar to other institutions of the time in that the early years of little regulation of student living arrangements soon gave way to greater regulation of facilities. As the dormitories became more attractive, they were also placed under closer surveillance (Lucas, p. 204). However, both men and women students were allowed to live off-campus in suitable boarding houses. If it was unavoidable, students could room in boarding houses which may not have been. so suitable in a town with large numbers of Chautauqua visitors. Women students at the new Florida State college for Women were not allowed to board off campus at all. Instead they lived in one of the college's two cramped wooden dormitories built in 1901 (Sellers, p. 15, 18-19). 
The dormitory for young women built in 1895

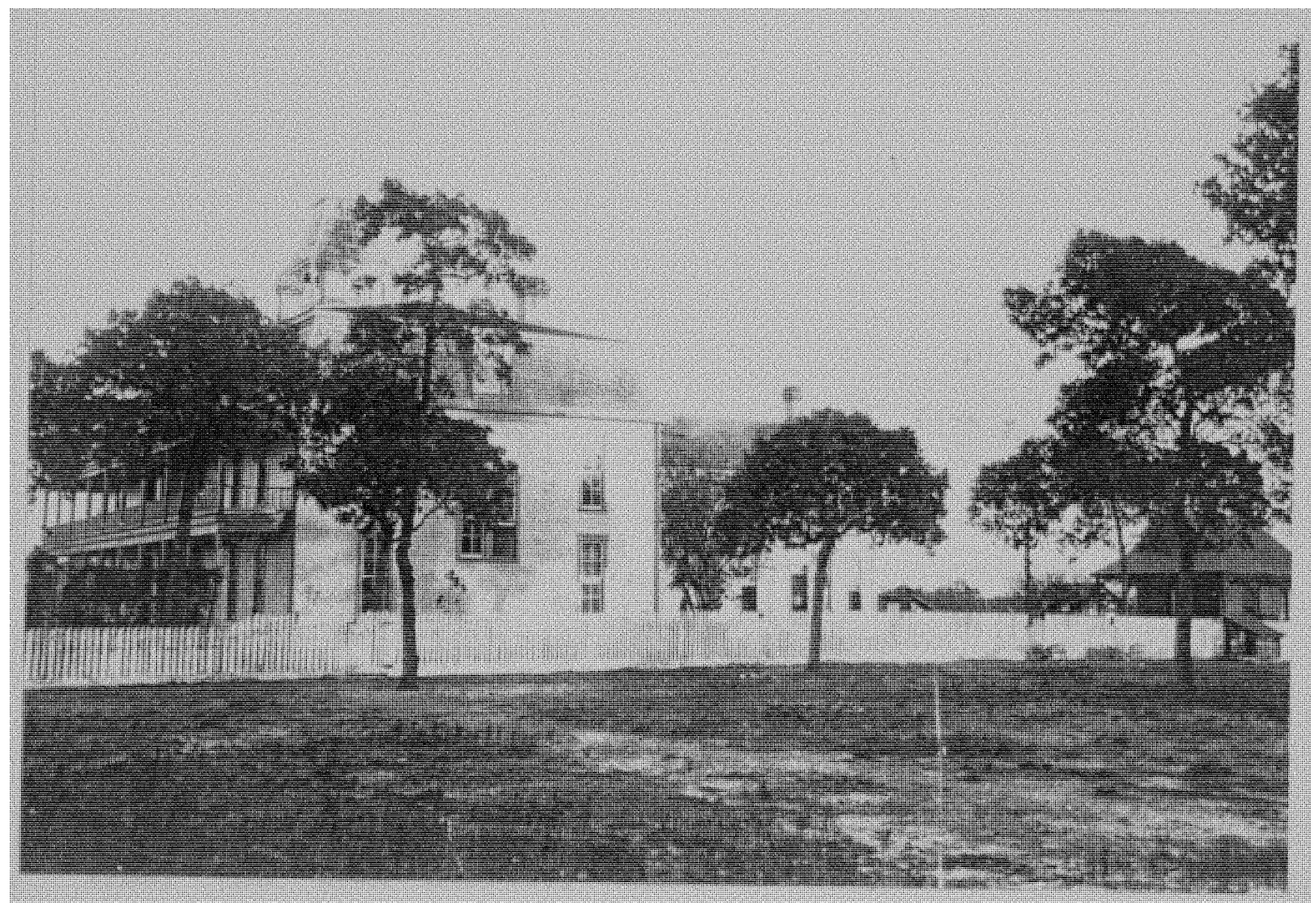




\section{Life outside the classroom}

The school administration advertised life in DeFuniak springs as a special benefit for students. The town had the reputation of a health resort and cultural center, only fourteen miles from the beautiful sandy beaches of the Gulf of Mexico but far from the fevers of other regions of Florida. W. S. Norwood reported to the state legislature in 1889 that "the healthfulness and accessibility of DeFuniak springs..render it...an admirable residence for students" (Catalog, 1889, p. 7). The school even claimed that "malarial troubles never originate here and students who come from unhealthy places with poisoned systems usually recover fully in a short time" (Brochure, 1900, p. 3). The town fathers advertised DeFuniak as a place to get away from tropical vegetation, hanging moss, and the "attendant malaria and close, debilitating atmosphere" (Beautiful DeFuniak Springs, p. 3). During the yellow fever epidemic of 1888, the town strictly enforced a quarantine on travelers from affected counties (Weekly Critic, Oct. 24, $1888,1: 3)$.

The Florida Chautauqua was a great added attraction for the students of the normal school. The lectures, stereopticon slide shows, parades, illuminations, food and excitement of the chautauqua were apparently greatly 
enjoyed by the students, who were encouraged to attend the lectures and entertainments, provided they did not interfere with school work. The chautauqua management sold season tickets to students for $\$ 1.75$ for many years. In 1904, the price was raised to $\$ 2.00$, but was still a wonderful bargain for a pass to hear music, attend evening concerts on the lake, see impersonations, and listen to some of the best-known speakers in the United States. The Chautauqua, with the cooperation of the local railroads, offered excursion trains during the season to Pensacola, the beaches, and the ruins of Fort Pickens. Visitors and students could arrange to go on "jolly" ox-cart rides to the old scotch settlement and to Ponce de Leon spring (DeBolt, p. 9) In 1899, the Chautauqua thrilled audiences with the first motion pictures. Visitors could also listen to gramophones the "latest and best Talking Machines" (Messenger, March $1899,7: 1-2)$.

During the rest of the school term, the town offered tennis courts, rowing, and sailing on the lake. Students could relax outdoors at Alpine Park, with its romantic pagoda built over the water (Heritage Association, 1994 Calendar). Floridians enjoyed hunting and fishing and DeFuniak offered both in abundance to visitors and residents (Turner, p. 22). Local baseball teams composed of residents and students played on warm afternoons. 
After the game, Stubbs and Shapley sold lemonade, sodas, and lunches to players and spectators (Baseball program, 1900).

A short walk over from College Avenue, where the school buildings were located, was Baldwin Avenue, where the trains stopped and the shopping district was located (Sanborn Fire Insurance Maps, 1912). The railroads had brought everything from stoves to lingerie to even the most isolated Southern country stores, and southerners loved the stores (Ayers, p. 83). The fine plate-glass facades of downtown DeFuniak must have enchanted students from rural districts. Students, farmers, chautauqua visitors and townspeople shopped at the Big store, directly across from the railroad depot, and owned by Mr. W. L. Cawthon. Next door to the Big store, a dentist and pharmacist, Dr. Landrum, ran a fine pharmacy with large windows, plate-glass display cases, and fancy goods for sale (Messenger, March 1899, 8:3). Dr. Landrum's pharmacy must have sold items such as those recorded in a similar North Carolina pharmacy, including cigars, toilet paper, malted milk, Velvet Skin soap, Ayer's Hair Vigor, Pear's soap, cologne, rose water, and pomade (Ayers, p. 91). Respectable women did not wear makeup, so only very discreet cosmetics were sold. While shopping, students could enjoy the new drink sweeping the South - Coca Cola. 
The Big Store was the center of DeFuniak Commerce. Mr. W. L. Cawthon was so respected that the school asked him to act as treasurer, collecting funds, making disbursements, and filing an annual report with Tallahassee. Students were advised to use Mr. Cawthon as their banker, depositing funds for sudden trips, emergencies, and purchases with him (Biennial Report, 1898-1900, p. 195). The store was named the "Opera House," and the "Busy Corner," but everyone knew it simply as the Big Store (Messenger, Dec. 1898, 8:3, and March $18998: 3)$. A customer could walk into this modern establishment and expect to find a wonderful selection of goods, including penny candy, knives, crockery, groceries, millinery, shoes, saddles, furniture, stoves, cologne, funeral necessities and fine calico dresses.

Other merchants also solicited the students patronage. If the Big store didn't have it, maybe Eddy Has It! did. Eddy advertised choice groceries, shoes, hats, umbrellas, tinware and hardware at "down in the cellar" prices (Messenger, June 1899, 10:2). T. M. King, in a new steel covered building, "was glad to see his friends and furnish them with everything." Or, the Crescent store cordially invited customers to inspect its new goods (Messenger, March 1899, 10:3). If none of the local general stores had what the student needed, there was always mail-order from Sears Roebuck and Montgomery 
Ward, to which Southerners were "much addicted" (Ayers, p. 87). Young women looking for that special dress could write to the Bee Hive in Columbus, Georgia, and immediately receive samples of dress goods, silks, satin, and lace (Messenger, March 1899, 6:3).

For a nice haircut, Mr. Helm's Chautauqua Barber Shop offered "neat work and courteous attention" (Messenger, Dec. 1898, 7:1). While in the barber's chair, students could read one of the several newspapers published in town (Servies, 1982). If one wished to be photographed, Mr. Hope Cawthon had built up a fine business by doing "splendid work" (Messenger, March 1899, $8: 2$ ). And, when tragedy struck, as it so often did, Mrs. s. Woodington dealt in funeral supplies and would fill telephone and telegraph orders (Messenger, Dec. 1898, $8: 1)$.

One type of entertainment that was emphatically not available to students was drinking. DeFuniak, like hundreds of other southern communities, had adopted local option. Neighboring counties and most of the states of Alabama and Georgia were dry (Ayers, p. 178). Walton County certainly did not want to allow enterprising bar owners to set up shop in town, hanging nude pictures and allowing loud, obscene language (Ayers, p. 178). Both the town and the county had prohibited the sale of liquor and DeFuniak additionally had inserted a clause in the 
deeds of all town property permanently prohibiting the sale of liquor on the premises under penalty of forfeiture (Catalog, 1904, p. 7). The Weekly Critic in October 1888 indicated that two local residents had been in trouble with the law for selling liquor and undoubtedly there were ways to buy illegal beverages, but the school catalogs all emphasized to concerned parents that "there is not a saloon in twenty miles" (Weekly Critic, 4:3, Catalog, 1898, p. 7, 1900, p. 3, and 1901, p. 11). Furthermore, there were no speakeasies, or "blind tigers," in town. Principal Bennett said that "blind tigers have no existence here, nor do any dens of gambling or vice" (Catalog, 1904, p. 7).

The town of DeFuniak springs and the normal school were on excellent terms. It was very popular at the turn of the century to decorate both homes and classrooms with portraits of distinguished men. The ladies of the town gave teas to raise money for the purchase of portraits of distinguished American men (and the European educators Pestalozzi and Froebel) to hang in the normal school classrooms and library (Normal Messenger, March 1899, $2: 1)$. Women from town and the young ladies from the normal school dressed in colonial costumes for one of these teas, helping to raise money for twenty five portraits (Normal Messenger, June 1899, 5:2). The normal school was instrumental in helping the county to 
establish a consolidated public high school. Normal school graduates taught in the town and county, and many future prominent citizens of DeFuniak springs attended the normal school. The members of the ladies library society included students, graduates, and faculty, and students were welcome to use the library. A local contractor, J. H. Kruse, whose daughter attended the school, embedded a glass jar in the cement of the northeast corner of the water tower, including a catalog from 1901, a complete list of students from 1901-01, the Delphian Literary society constitution, and a Chautauqua program (Minutes, May 9, 1902).

The normal school offered organized extra-curricular activities. Every college and university during the last decades of the nineteenth century encouraged literary societies and organized athletics. State Normal College students were urged to join the "Delphian" society, a society consisting of students and teachers of the Normal School which met weekly and featured debates; essays, and parliamentary study (Catalog, 1898, p. 21). Members of the Delphian Society always had a prominent role in the entertainment for the school's commencement ceremonies (Commencement Programs, Faculty Minutes March 30, 1904). The president of the Delphian Society was listed in school catalogs on the same page as the faculty. Both men and women participated actively in the Delphian 
Society. In 1899, the officers included Miss Lonny Landrum, Miss Etta Jones, and Miss Lell West as secretary, treasurer, and literary critic (Messenger, March 1899, 9:1-2).

Graduates of the normal school joined the Alumni Association, formed in 1888. The Association hosted an evening reception every year during commencement. The 1897 program included a piano solo, prayer, addresses, a quartet, the reading of an essay, a violin solo, a declamation, and a vocal solo, followed by refreshments (Alumni Association, Invitation 1897).

Library facilities until 1901 were limited. The school reported only one hundred books in the library in 1898 (Commissioner of Education, 1898, Vol. 2, p. 1819). After the legislature appropriated five hundred dollars for the library in 1901, students could use a library with 1,500 "admirably selected" works of reference and standard literature, indexed by the card catalogue system, and in the charge of a "competent librarian," probably a member of the faculty. The library supplied a reading table with twenty-five to thirty of the "best" daily, weekly and monthly publications, including the Forum, Educational Review, Review of Reviews, Public Opinion, Outlook, American Education, Harper's Weekly, Success, Ladies' Home Journal, Youths' Companion, Scribner's Magazine, School of Arts, World's Work, 
Cosmopolitan, Primary Education, American School Board Journal, the Ram's Horn, and the Florida Times Union. Complete files of many of the publications, running back "many" years, and "the most complete periodical index published" were available to the students.

The school encouraged athletics and "physical culture." As noted earlier, college administrators had a special interest in maintaining the physical well-being of women students. Ante-bellum southern female seminaries and colleges scheduled walks as a central part of the daily routine (Farnham, p. 126). President Walker emulated other southern institutions by instituting military drills for the young men. The ladies were required to perform "systematic" calisthenics. The drills and calisthenics would "cultivate order and make discipline easy and natural." To counter the effects of military drill, students also studied music, for "song makes one gentle of mien and light of heart" (Catalog, 1893, p. 18). Later principals ended military drill and encouraged newer methods of physical culture. Principal Hayes urged students not to neglect this aspect of healthy living, saying:

Outdoor exercise is also very desirable, and no student should fail to take a walk, or engage in some sport in the open air, daily. It is not a 
loss, but a saving of time, to do so. However, we would caution students against violent exercise, which necessarily results in harm. The same amount of exercise near the same time every day is most beneficial and most pleasant (Catalog, 1898, p. 8).

In 1898, the young men organized an Athletic Association to "secure for ourselves better systematical physical development and for the pursuit of manly sports." The young men paid annual dues of fifty cents and kept records of their weight, which ranged from ninety-two pounds for Mr. Frank Bludworth to one hundred and thirty nine for Mr. O'Haver. The members hauled sawdust, built playing grounds, and installed parallel bars. They especially enjoyed baseball and basketball (Records of the F. S. N. Athletic Association; Constitution and By-laws). The normal school was concerned, as were other schools and colleges both then and now, with the proper role of organized athletics. In 1904, Principal Bennett wrote that "Athletics is not advanced here for its own sake, but for recreation and needed physical development." He observed that students played basketball, baseball and football with "enthusiasm and zeal, the first being especially popular." During the Chautauqua season, teams from other schools played Normal School students on the home grounds, but under no 
circumstances were students permitted to leave DeFuniak. springs to play match games of any kind. Students at institutions of a "different type" could go on such excursions, but the students of the Normal were "too busily engaged in their studies," and felt "too serious a responsibility in the use of their time," to take trips with the team (Catalog, 1904, p. 41). Supporters of their favorite team could cheer for them with the "Yell of the Athletic Association":

$$
\begin{array}{r}
\text { 'Rah! 'Rah! 'Rah! } \\
\text { 'Rah! 'Rah! 'Rah! } \\
\text { Athletic Men! F. S. N.! }
\end{array}
$$

Hurrah! Hurrah! for the F. S. N.!

Hurrah!

(Catalog, 1901. p. 44).

The young women formed the Diana Club in 1901. Many of the women joined, participating in outdoor sports, such as basketball, which was played on private grounds, and a class in physical culture, with Indian club swinging as the chief exercise. Miss Davenport, the Latin teacher, took charge of Indian club swinging (Catalog, 1901, p. 45).

All the interest in athletics created a demand for a gymnasium, built in January of 1902, and which was described as "handsome." Now students could participate in physical culture and gymnasium classes, which offered 
regular and systematic exercise, which would keep them in the "best physical condition for work" (Catalog, 1904, p. $45)$.

Finally, students were required to attend sunday church services unless prevented by illness or bad weather. Floridians, like other southerners, were evangelical protestants. In 1906, ninety percent of Floridians were Protestants, of whom 91,988 were Baptists, 82,862 Methodists, and 7,051 Presbyterians (Grantham, p. 20). Normal school students had a choice of attending the "all white" Presbyterian, Episcopal, Southern Methodist, Universalist, or the Baptist churches (Mckinnon, p. 366, (Catalog, 1904, p. 7).

Observers at the turn of the century frequently commented on the religiosity of southerners, so the students probably did not find compulsory church attendance a hardship. "Every third southerner was an uncompromising and fanatical puritan," and "nowhere else... [could one hear] moral precepts more explicitly, even dogmatically, asserted than by christian people of the South" (Ernest Abbott, in Ayers, p. 168).

The school did not forbid dancing, drinking, or smoking. The catalog merely stated in 1888 that students could not at any time visit ten-pin alleys, billiard rooms or other places of dissipation (p. 9). Soon, the school dropped even this regulation. The Reverend 
Walker, principal from 1893 to 1897, required that students be prompt and cheerful and "do right as well as they knew" (Catalog, 1893, p. 8).

Miss Mary Lou Cawthon, a normal school student, was photographed in 1901 driving DeFuniak's first automobile (Heritage Association, 1992 Calendar). By 1902, enough automobiles had reached DeFuniak Springs for the school to rule that women living in the dormitories were not allowed to go riding in cars with men (Catalog, 1902. p. 27). Still, there were few regulations compared to other colleges with women students, because school administrators believed that a student body composed of teachers seldom needed discipline. No dress code or student code of ethics was ever considered necessary. Given DeFuniak's proclaimed absence of vice and the evangelical horror of dancing, mixed bathing, drinking, and smoking, it is unlikely that the normal students "caroused" in their free time. The local churches invited students to join in the activities of their youth groups, and by 1903 the campus had an active Young Women's Christian Association (Catalog, 1904, p. 7, 44).

The highlight of the school year was graduation in May. Governors and famous speakers attended the exercises, which lasted two and three days. Graduates and their families, students, faculty, and alumni enjoyed formal programs including a sermon, string quartets, 
vocalists, dramatizations, declamations, and dinners (Commencement programs, 1888 and 1891, Minutes, May 1904). After the dinner, the men undoubtedly stepped outside to enjoy a cigar made in Tampa or imported from Havana. The actual graduation ceremony, held in the evening, was illuminated by candles, which "lent a subdued and pleasant effect to the brilliant scene" (Normal Messenger, June 1899, 4:3).

Students at the Florida State Normal School enjoyed a much greater variety of activities and events, because of the chautauqua, than did the students at almost any other normal school at the turn of the century. Still, the school expected students to conform to prevailing standards in the matter of church attendance, and the excitement of the Chautauqua did not include opportunities for debauchery at "blind tigers." Normal students, like many students today, used their free time to write letters to family, visit stores, attend church functions, take walks, participate in athletics, and spend time with their friends in the dormitories and in town. 
Commencement at the Florida state Normal College (undated photograph)

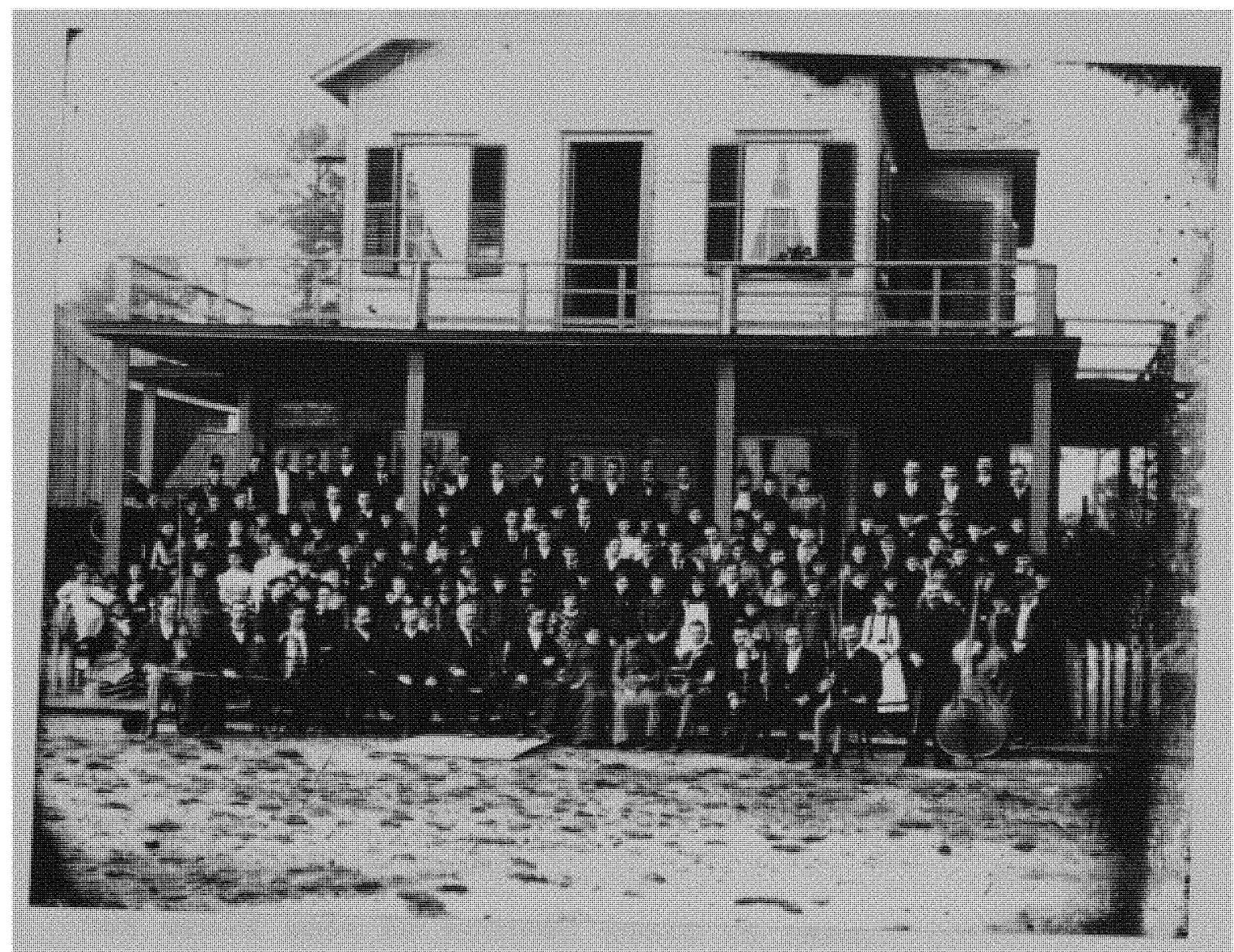




\section{Closing of the Florida State Normal College}

In 1905, many progressive educators and economical legislators believed that Florida had too many institutions of higher education for white students. The normal school at DeFuniak springs was one of seven institutions, including the East Florida seminary at Gainesville, the Florida state College at Tallahassee, the University of Florida in Lake City, the South Florida Military Institute at Bartow and the Institute for the Deaf, Dumb and Blind in st. Augustine. The state also supported a normal department at the privately owned St. Petersburg Normal and Industrial School. In 1903, the legislature authorized yet another institution, the Florida Agricultural Institute at Kissimmee. In 1896, Superintendent sheats compared the system of higher education in Florida to the situation of a poor man with more children than he could provide for, trying to decide which child would have to leave (Biennial Report, 189496 , p. 64). The Kissimmee Institute had not yet opened, but would soon be another mouth to feed.

The schools competed with each other for funds and for students. Some educators argued that the competition for students encouraged the schools to establish preparatory departments, which then provided the counties in which they were located with high schools at state 
expense.

The normal school at DeFuniak springs received extremely modest appropriations from the legislature. For the first four years of its existence, it received annual appropriations of four thousand dollars, which were cut to three thousand five hundred by the legislature in 1891. As a comparison, Alabama gave the normal school at Florence seven thousand dollars a year (Commissioner of Education, $1887-88$ p. 464-465; Biennial Report 1890-92, p. 119). When Reverend walker began his term as principal in 1893, the appropriation was raised a hundred dollars a year, to three thousand six hundred dollars, plus an additional fourteen hundred dollars for building and repairs (Commissioner of Education 1892-93, Vol. 2, p. 2002-2003). Walker lengthened the school term to thirty six weeks, but it still was four weeks shorter than the forty week term of other southern normal schools. In 1895, the legislature raised the annual appropriation to five thousand dollars and gave the school five thousand seven hundred dollars for improvements, which was used to build the women's dormitory and an additional classroom (Biennial Report, 1894-95, p. 114). In 1897, the legislature awarded the school an appropriation of six thousand dollars (Commissioner of Education, Vol. 2, p. 2018-19).

In 1901, the legislature gave the school more money 
than it ever had before, awarding the school a seven thousand dollar annual appropriation, and funds for library books, the purchase of a spring for water, and installation of a water and sewer system. Legislators also financed the building of a laboratory, a gymnasium, and a model school. Additionally, in 1901 the legislature established the county scholarships to the normal school, giving the school four thousand five hundred dollars each year for that purpose. The total appropriation in 1901 was sixteen thousand, four hundred and ten dollars (Biennial Report, 1900-02, p. 185). Principal Hayes must have felt very flush! In 1903, Superintendent sheats persuaded the legislature to give the school funds with which to build a model kindergarten and a manual training department (Biennial Report 190204, p. 433).

The amount appropriated was modest compared to the new normal school which the neighboring state of Georgia opened in 1891 at Athens, and to Alabama's normal school at Florence. It was a small portion of Florida's total expenditures for higher education. Between 1881 and 1905 Florida spent $\$ 1,626,240$ for higher education (Proctor, 1958, p. 465). The total amount expended on the DeFuniak normal school between 1887 and 1905, including scholarships, was $\$ 124,093$. The land had been donated, but other institutions had received land from donors as 
well. The normal school received only 7.6 percent of the total expended between 1881 and 1905 .

Despite its low operating costs, the administration of the normal school demonstrated uneasiness about the school's location early in its history. In 1889, a legislative committee described DeFuniak springs as "a most desirable location for an educational institution" (Catalog, 1889, p. 9). However, by 1892, there was discussion about the location of the normal school, because the school board of Marion County urgently requested their representatives in the 1893 legislature to push for moving the school to Lake Weir, saying that they had been informed that the removal of the state Normal from DeFuniak was under consideration (Lovell, p. $35)$.

In 1895, the Reverend Walker wrote, "The truth cannot be denied that the remoteness of the school from East and South Florida militates largely against the attendance from those sections." He wrote that this was mitigated by the generosity of the railroads, and said he was "persuaded that if this truth were generally known, as also the superior merits of the work of the institution, there would be a much larger attendance from the remote portions of the state." The normal school had been characterized by critics as a high school for walton County, for he wrote that "in spite of all the 
difficulties, and misrepresentations as to the Normal College being a merely 'local' institution, there were in attendance over forty per cent of the students from eighteen counties outside of Walton during the year 18956" (Biennial Report, 1894-96, p. 111-112).

The normal school's catalogs indicate that the administration recognized the location of the school as a problem in attracting students and maintaining state support. In 1898, the school catalog said, "Though the school is not as centrally located as it might be with reference to the other parts of the state, this is more than compensated for by the cheap living, healthful surroundings, temperate society, literary advantages, etc." (p. 7). This statement was repeated in the catalogs of 1901 and 1902. In 1900, the school's brochure wrote, "DeFuniak springs, though remote from some parts of the state is withal an excellent location for such an institution of learning" (p. 3 ).

By 1905, the fastest growing centers of population in Florida were the central and southern parts of the state, far from DeFuniak springs. In 1860, four-fifths of Florida's people lived in the northern tier of counties along the state line bordering Georgia and Alabama. Leon County, where Tallahassee is located, was the largest county, and Pensacola was the largest city (Dietrich, p. 1). In 1880, the fourteen west Florida 
counties which were home to the majority of the normal school students had 45,655 white residents, or 32 percent of the the total white population of Florida. By 1910, although the white population had grown by 161 percent, the rest of Florida had grown even more, increasing 235 percent (from population figures in Dietrich, p. 18-21).

Southern educational reformers, including Florida Superintendent sheats, embraced the idea of school consolidation as a solution to the problems of southern schools. Reformers saw the wretched rural schools as institutions which perpetuated ignorance, isolation, poverty, and poor health in the rural south. School consolidation would provide better education more cheaply in the rural areas. Children could be transported to larger district schools by school wagons. Consolidated schools would take the children and their parents out of their narrow environments, break down parochialism, socialize isolated rural southerners, and prepare them for life in the New South of commerce, industry and Yankee cleverness (Link 1986, p. 94). Deep South state officials advocated school consolidation as a necessary step to bring southern children into the modern world of the new century.

In 1891, Florida governor Francis Fleming connected the consolidation movement in the common schools with the consolidation of higher education, saying that "if our 
means had been concentrated in a state university under efficient management we would possess an institution of learning of high rank which would compare favorably with those of most other states" (Bristol, 1952, p. 31). When Superintendent sheats took office in 1893, he urgently advocated consolidation of the common schools and used his office to force every county to establish at least one senior high school. Sheats believed that the benefits and economies of consolidation should extend to higher education as well, and began to promote the idea in 1895 .

In the Biennial Report of 1898-1900, Sheats wrote:

The trend in the common public schools everywhere is consolidation. The watchwords are, fewer schools, longer terms, better equipment, stronger and more professional teachers. This is being brought about in the common schools through a system of transportation of pupils. The question of location as regards higher education is well nigh eliminated by the cheap rates, quick transit and ready communication brought about by the modern system of transportation. A student five hundred miles from home is as near in point of time as one forty miles away in the days of stage coaches, a generation ago. The number and location of colleges 
are mere questions of expediency to be determined by the questions: Will consolidation reduce the cost? Will it ensure better educational facilities? The tendency of the times is towards the consolidation of the weak into mammoth institutions. It is of daily occurrence in commerce, in manufacture, in transportation, and in every phase of human endeavor. Educational enterprise can not afford to exercise less forethought (p. 171).

In 1905, Florida inagurated a progressive governor, Napoleon Bonaparte Broward, whose ambitious ideas and improvements for the state ranged from bringing the railroads under control to draining the Everglades. Broward disliked the competition among the state institutions for funds and recommended a thorough reorganization of Florida's system of higher education, saying in his inaugural address "I do not believe that the management of these colleges and seminaries should be put in the attitude of beggars before the Legislature for the means of existence" (Adams, p. 136). He believed that Florida's colleges and seminaries had failed to offer instruction above the high-school level and that, by accepting underprepared students into their preparatory departments, they had actually lowered educational standards throughout the state (Proctor, 
1950, p. 225).

Other problems with the colleges had developed. In 1901, the West Florida Seminary became the Florida state College. It was coeducational, had a dynamic young president, A. A. Murphree, and was growing in enrollment and prestige (Bristol, 1952, p. 25). Resentments and jealousy grew between the Tallahassee college and the Florida Agricultural College in Lake City. In 1903, the Florida Agricultural College ended coeducation at the Lake City campus, and changed its name to the "University of Florida". The new university, under president Taliaferro, began an intense campaign to "beat out" the Tallahassee college. Taliaferro believed that by changing the institution to an all male school, his university would gain greater funding, size, and recognition (Proctor, 1958, p. 470). Taliaferro was replaced in the presidency by Dr. Sledd, who continued the campaign to make the Lake City school into Florida's flagship university. Dr. Sledd made a point of observing to legislators that Latin was part of the curriculum at all of the state-supported schools, and that he wondered if it was really economical to pay so many Latin teachers in a state such as Florida. A series of unsigned articles, written by an administrator at the University of Florida, appeared in newspapers around the state, describing the mismanagement and wastefulness of 
Florida's system and the advantages of consolidation (Proctor, 1958, p. 467-470). In 1905, the university at Lake City submitted a padded budget to the legislature for the next two years, hoping to provoke the other schools into doing the same and bringing the issue to a head (Bristol, p. 24).

The other institutions responded. The combined total requested by the schools for 1905 to 1907 was $\$ 700,000$, which was more than three times the last appropriation. The legislators were shocked. The request was immediately reduced by several hundred thousand dollars, but by that time several bills to reform Florida's system of higher education had been introduced (Proctor, 1958, p. 465).

On May 3, 1905, Representative H. H. Buckman of Duval County spoke to the legislature, saying that "a bill would be soon introduced providing for the maintenance of a real university, a girls' school, and the normal, and that all other schools would be run as regular high schools" (Bristol, p. 23). On May 9, he introduced House Bill number 361, which abolished all the existing state institution of higher education except for the Institute for the Deaf, Dumb and Blind in st. Augustine and the Florida Normal and Industrial College for Negroes in Tallahassee. The state would then establish two new institutions of higher learning for 
Florida, to be called the "University of the state of Florida" and "Florida Female College."

The new institutions would be administered by a central Board of Control and were to be segregated by sex. The teacher-training department for the state would be located not at the women's college, but at the all male university. The property of the abolished institutions would revert to the state, and the normal department at the St. Petersburg Normal and Industrial School, which the state had funded, was abolished (Abolishing and Establishing Act, 1905).

Debate over the Buckman bill on May 19th in the Florida House was so intense that the Senate recessed so that senators could listen in the gallery (Tampa Morning Tribune, May 20, 1905, 1:7). On May 20th the senate heard the bill, eating chipped beef sandwiches and pickles during the reading, which took an hour (Tampa Morning Tribune, May 21, 1905, 1:7). One opponent, William A. Bryan of Chipley, a West Florida town near DeFuniak springs, said the provisions of the bill were as "cruel as hell and as wicked as the iniquity of Satan's own heart" (Proctor, 1950, p. 225). None of the senators or representatives discussed the bill's provisions for the ending of coeducation in Florida (Bristol, p. 32). When the bill passed, thirty-seven to twenty-two, a radically different system of higher education began in 
Florida.

The legislature then debated the location of the two new institutions. Years before, the seminary land grants had specified that one institution be located in East Florida and one in west Florida, and the seminary fund still generated a small amount of interest. In any case, legislators followed tradition and located the schools in the separate sections of the state. Tallahassee became the home of the female college, which occupied the grounds of the abolished Florida state college. The men's university was established at Gainesville on the East Florida Seminary grounds.

In Lake City, townspeople were stunned and so furious that they challenged the constitutionality of the Buckman Act and obtained a court injunction against removing any equipment from Lake City to Gainesville. W. S. Cawthon, who graduated from and later taught at the Florida State Normal School, was by then the librarian at the new university, and supervised the move to Gainesville. He accompanied the wagons to the Lake City railroad station with a loaded shotgun across his knees (Proctor, 1958, p. 526). The reaction in DeFuniak must have been similar. In 1911, John B. Mckinnon wrote, "and after it had been taught here, successfully for seventeen consecutive years, giving general satisfaction, the Legislature of politicians met in Tallahassee and took it 
away from us without giving a single legitimate reason for so doing" (McKinnon, p. 364).

The ending of coeducation in Florida may have appeared to be a progressive aspect of the Buckman Bill to state legislators ignorant of contemporary education in general and Florida's education in particular (Bristol, p. 32). Floridians apparently had no prejudice against coeducation, and there are no records of problems in the coeducational institutions. In 1893, the Reverend Walker wrote that "The association of the sexes when kept within the limits of propriety and decorum, tends to the good morals and gentle manners of both" (Catalog, 1893, p. 11-12). The 1893 catalog of the Florida state Agricultural College in Lake City indicates that ten years before that institution abolished coeducation at its campus, it actively sought women students:

Many years experience have proven the wisdom of educating men and women in the same class. The influence on each other is good. Both do better work than when educated separately, and it seemed only fair that the young women of Florida be given the benefit of the fine educational plant that is gradually being collected at Lake city. They will pursue the same courses as the young men and recite in the same classes. This is the method pursued in 
all the colleges and universities to which both men and women have been admitted, and has been proven to be a good method. It has the endorsement of the ablest advocates of education, both men and women. Young women will find friends and advisors of their own sex in the faculty, and among the wives of those professors resident at the college (Florida Agricultural College catalog, 1893-1894).

However, at the time the Buckman bill passed only the county superintendents of schools objected, opposing any plan to close "the doors and advantages of the state colleges to the young women of Florida." They declared that "in the nature of things, boys and girls should be trained up together, since they are to live together as man and woman, and need to be taught their true relationship" and described separate educational facilities as "relics of a monastic age" (Proctor, 1958, p. 486)

Still, almost every southern state in 1905 had a state-supported college for women. Of the seven state colleges for women, all were in the South, where the rising middle class demanded better opportunities for their daughters but saw coeducation as undesirable (Orr, p. 33). The new college in Florida brought the total to eight. In 1944, sociologist L. M. Bristol located 
several surviving legislators who had voted on the Buckman Act to question them about the single sex provisions of the bill. Their vagueness on the issue led him to conclude that the legislators never understood the provisions or implications of the bill, and believed that they were bringing the system in Florida up to par with neighboring states (Bristol. p. 32). Also, a strong backlash against women in higher education was in full swing by 1905. Articles appeared regularly in American magazines and journals describing "sex repulsion," the negative effect on male students of having to attend colleges with women, and on "race suicide," and the danger of having too many women teachers. Prestigious established coeducational institutions such as stanford and the University of Chicago limited the number of women students and the courses of study women could elect.

Female graduates of the institutions closed by the Buckman Act could receive certificates from the state College for women, and males from the University of Florida. The applicants needed only to make a written request and remit one dollar. The earlier women graduates of the normal school quickly made arrangements with their new alma maters. The college for women awarded at least sixty diplomas, and President Murphree stated that "about seventy-five of the old graduates came to the Commencement to receive their diplomas" (Adams, p. 
169).

The town fathers of DeFuniak springs made a momentous decision, described by John McKinnon:

Not long after the furniture was moved out of the buildings Rev. F. L. Higdon, the pastor of the Presbyterian Church in DeFuniak springs, came in a little early to the Wednesday evening prayer meeting, sat down by the writer and said, "If there is one thing above another..that we do need in this section, it is a religious high school or college, and this normal school property is an ideal locality for such an institution and our church ought to take steps at once to procure the money for this purpose, before the state disposes of it (McKinnon, p. 364).

Soon the old Scotch Presbyterians had raised the money and purchased the property, organizing an academic school, leading up to collegiate work under the auspices the Florida Presbytery. The object of the new school, Palmer College, was to give the public an institution of learning where children would be educated under Christian influences. By 1912, Palmer College taught children from the first grade to the sophomore year in college (Palmer College Catalogue, 1912, p. 1-5). The college stayed open until the late 1920 's. 
By 1906, the state had disposed of all the property of the abolished institutions (Biennial Report, 19041906, p. 205). The normal school's kindergarten equipment and teacher Anna Chaires went to Tallahassee to form a kindergarten training department at the new Florida state college for women (Sellers, p. 25). The principal of the State Normal School, H. E. Bennett, went to Gainesville to head the normal department at the university, taking with him the records of the Florida State Normal College for White students at DeFuniak Springs.

The Faculty and students

While biographical information is scanty, it is probable that the faculty and students of the Florida State Normal College shared important characteristics. They were southern, most born in the Deep South states. Principal Felkel, the Reverend Walker, and Mrs. Reeves were old enough to remember the civil war. The rest of the faculty were born in the first years after the war during Reconstruction. All the students were born between 1860 and 1890. The faculty and students shared memories of the Reconstruction and Redemption eras, and had their parents' memories of civil war. Still, educators tend to think less in terms of the past than they do of the future, and surely these educators were as 
caught up in the excitement of living in the New South and the great educational crusades of the day as were other southern educators.

Their political views were probably conservative and many of them would have been surprised by demands for women's suffrage, as Florida was one of the last southern states to have a suffrage movement. Florida's first serious suffrage association was not formed until 1912 in Jacksonville (Wheeler, p. 149). Even the students at the Florida state College for Women did not form a suffrage club until 1917 (Sellers, p. 53). Undoubtedly the male faculty and students voted Democratic. In 1888 an unnamed normal student campaigned in walton county for Grover Cleveland's election, arguing that the Democrats of Florida were the "friend of the people, bringing internal improvements," including the insane asylum, a deaf and mute asylum, an agricultural college, and two normal schools (The Weekly Critic, Oct. 24, 1888, p. $2: 2)$.

Women students and faculty members enjoyed the emotion and sentimentality of Victorian America. Young ladies kept Bibles by their bedsides and treasured their autograph books, in which friends and teachers wrote charming, heart-felt sentiments (Erskine, autograph book). Students penned careful letters to family members and close friends, collected frilly mementoes, decorated 
with fine needlework, and put their hair up. They wore long dresses, a small piece of jewelry, and, in public, a hat. The men wore short hair. Beards were not in style, but several of the men had finely waxed mustaches. For formal occasions, they wore high white collars with their starched shirts (Brochure, 1900, photograph of commencement exercise).

Faculty and students shared religious beliefs. Florida in 1900 was a solidly evangelical protestant state. DeFuniak springs had a strong Presbyterian presence and members of the cawthon family founded a Universalist Church, but there was no synagogue or Roman Catholic Church. Other Florida schools probably had very little more diversity. The Florida Agricultural College catalog of 1897 listed seven students from Cuba, who may have been Roman Catholic, but required all students to participate in Bible study. The faculty of the west Florida Seminary in 1899 was "solely composed of religious men and women" (Normal Messenger, June 1899, p. $10: 1)$.

The faculty and students shared a victorian sense of proper behavior. The school catalogs stressed in 1888, 1890, and 1893 that for the maintenance of discipline, the faculty relied principally upon appeals to the moral sense of the students, stressing that "No student who is insensible to such appeals will be permitted to remain an 
inmate of the institution." In 1904, the catalog described a student body which had internalized social codes, and that "As gentlemen and ladies should be, and in life are, they are left to control themselves," motivated by the "wholesome desire to stand well in the eyes of their instructors and associates." Principal Bennett explained that "It is very seldom necessary to expel, for unruly students find themselves so unpopular and so strongly disapproved of by the student body that they are ready to conform to our standards or withdraw" (Catalog, 1904, p. 43). There were no records of expulsions in the Minutes of the normal school. The normal school had few rules, and those primarily had the purpose of making group life run smoothly, rather than that of controlling individual behavior. The 1888 catalog prohibited visiting ten-pin alleys and other places of dissipation, but this regulation did not appear in later catalogs (Catalog, 1888, p. 7). The 1904 catalog said, regarding church attendance, that "the majority of our student body are religiously inclined young people, and it has not been found necessary to make any specific regulation regarding attendance upon church services." Students conducted vesper services in the evenings after supper which were "very helpful and well attended" (Catalog, 1904, p. 44). Many Southern Protestants well into the twentieth century proudly "took 
the pledge," promising never to use liquor or cigarettes, and it is virtually certain that many of the students and faculty of the normal school had pledged to abstain.

The faculty minutes for the years between 1894 and 1905 only record two instances of misbehavior, other than receiving assistance on exams, which indicates the degree to which students and faculty shared ideas of correct behavior. In 1897, a young man in class " $B$ " had "been very irregular in attendance upon his classes and frequently is otherwise disorderly and disrespectful to the school." He was notified to appear before the faculty at 3:00 P. M. on Dec. 4, 1897, to account for his misconduct. He failed to appear, and word reached the faculty that he had "expressed his intention to remove self from school indefinitely." The faculty resolved that if he returned, he would be required to account for his frequent tardiness, for absenting himself from regular classes without permission, for leaving the College in a disorderly manner, and for failing to appear before the faculty. This young man was a member of a large local family of staunch Presbyterians who sent a number of children to the school. He had a change of heart, and in March 1899 appeared before the faculty and "answered in a satisfactory manner the charges enumerated against him" and was reinstated as a student in the state Normal School (Minutes). The 1900 census described this 
student as the head of his family, employed as a teacher, with several younger brothers and a sister at school. Perhaps his reformation was caused by the deaths of his parents. After graduating in 1901, he went to medical school in Iowa.

In 1899, a young couple at the school ran into trouble. The faculty summoned the female student, who had absented herself from the dormitory and from school, along with her male companion, who had to account for his absence from school. Their transgression was apparently not too serious, because after apologizing and explaining their absence, the matter was dropped (Minutes). Those were the only two instances of rule-breaking recorded in the Minutes other than "receiving assistance" on exams, which happened on three occasions. In May of 1900, two female students were told to appear before the faculty and answer to charges of receiving assistance in Arithmetic.

The first young woman confessed to having received answers from a male student on one problem, but denied receiving anything further. The second student at first denied having received any assistance but admitted that she had given a note to another student asking "only as to the meaning of some question on the board." She afterwards confessed to having copied a problem from the paper of yet another student. Later a third young lady 
appeared before the faculty and stated that one of the offenders had requested her to do three problems for her but that she had refused (Minutes). The students involved were spoken to "severely" and then retook the exams .

Another problem developed during the exams taken in December of 1900, when a young woman from DeFuniak Springs appeared before the Faculty and explained why she had in her possession during her Latin examination "certain notes likely to prove helpful in that exam." After hearing her explanation the Faculty agreed that she had not intended to use the notes in answering exam questions (Minutes).

In 1902, the third case of cheating recorded was much more serious than the previous two. The school expelled three women for "cheating and then lying to the faculty about it." Another student was suspended, and a fifth was advised to resign her scholarship, for giving information to the miscreants. This entry in the minutes was followed by a note written by Principal Hayes:

The Parties above gave satisfactory statements of confession and apology to be read to the school in their presence and wrote letters of confession to their parents. As they have been deeply affected, and the student body has also been deeply affected, 
and there is also serious legal doubt as to the authority of the faculty to take final action in this matter, the sentences have been suspended, leaving the above students "in terrorem" (Minutes).

None of the students involved in the incident stayed to graduate. Presaging the frustration today's college instructors feel when students fail to appear for exams, in 1902 the minutes reported that "all delinquents who failed to report for examination at the time specified be refused examination." The next entry reported that a date for reexamination had been scheduled.

The pedagogic texts selected for use at the school, which were used in schools around the country, vividly described the protestant and Victorian ideals to which the faculty, and presumably the students, suscribed. White's Elements of Pedagogy argued that the central aim of the school should be effective moral training, and that "sacred song, the literature of Christendom, and...faithful and fearless Christian teachers" were essential to the schools (1886, p. 328-330). Page's Theory and Practice of Teaching listed the habits worth cultivating by teachers: prudence, justice, fortitude, and order ( $p .71$ ).

White also wrote School Management: A Practical Treatise for Teachers and all other Persons Interested in 
the Right Training of the Young. This textbook includes a lengthy section of "materials for moral lessons," for all grades, including lessons, songs, stories, and literary gems. White urged teachers to use them in class to "awaken right feelings and quicken the conscience." Moral lessons for students included such things as "a kind deed is never lost," "idleness is the mother of want," "an honest man is the noblest work of God" (White, 1894, p. 240). Principal Bennett wrote of the pedagogic courses that "the central thought... is that the school is managed with the development of the pupil's character as the highest aim" (Catalog, 1904, p. 18). The students at the normal school were taught to share this belief.

The faculty and students also undoubtedly held common views of race and racial issues. Racial relations in the New South were characterized by increasing tension, segregation, and disfranchisement. In Florida, blacks effectively lost the vote with the institution of poll taxes and separate ballot boxes. The 1900 Florida census revealed that the great majority of blacks, largely illiterate, worked in the lowest jobs, as laborers in phosphate mines, turpentine camps, and on farms. The students and faculty knew blacks as laundresses and laborers and studied and worked in a school system which at all levels was segregated and intensely racist. 
Superintendent sheats, one of the most progressive school administrators Florida ever had, repeatedly defended Florida's segregated school system. In 1894 Sheats's report to the Commissioner of Education argued that taxes would be paid to support black education just so long as "their unwise friends will not intermeddle." He stated that "any effort to enforce mixed education...would forever destroy the public school system at one swoop" and that "the efforts Northern benevolent associations are making in this state to educate a few of them in schools with the whites are exceedingly exasperating....the race has too many loving guardians" (Commissioner of Education, 1893-94, Vol. 2, p. 1369).

In 1896, the National Educational Association's Department of superintendence held its national convention in Jacksonville. Superintendent sheats gave the welcoming address to city, county and state superintendents from around the country. After greeting them, he described the necessity for segregated schools. Sheats declared that after the Civil War, "the white boy ploughed to pay the tax while the negro boy sat in school." He went on to explain the situation as he saw it:

The negro is treated more than fairly in the 
matter of education.... Some are skeptical as to the value he will derive from it. At any rate, we do not desire the help or intervention of persons knowing nothing practically of the race, and who do not propose to live with the condition of affairs they would create.... We pray that no fanatic be encouraged to intermeddle for our molestation and the injury of that people (Proceedings of the NEA, 1896, p. 241)

In 1904, Principal Bennett of the Normal School coauthored a history of Florida for use in the public schools with Caroline Mays Brevard. Bennett wrote the section on the schools of Florida, which stated that one of the wisest provisions of the constitution of 1885 was the one which settled the race question so far as it affected the schools. "Two dangerous ideas were then prevalent in the state - coeducation of the races on the one hand, and, on the other, opposition to any education of the negro." The state avoided these dangers by instituting the "wise, permanent policy" that white and black children would not be taught in the same schools (Bennett, p. 229).

The three surviving issues of the Normal Messenger included jokes, mostly of the kind that especially appeal to teachers, such as ridiculous answers on exams and 
precocious statements by children. All three issues included racial jokes as well. The faculty of the normal school wrote and published the paper, and circulated it to students and boards of education around the state, who presumably did not think that racial jokes on the pages of an educator's paper were improper. Given the racial climate in Florida it would have been surprising if any of the students or faculty sought, for instance, to reform Florida schools by integrating them. Such an idea lay over half a century in the future.

The faculty

The school opened in 1887 with a faculty of three, Principal H. N. Felkel, Miss Lillian Outerbridge, and Mr. H. E. Graham (Catalog, 1888, p. 1). Miss Outerbridge and Mr. Graham were with the school a short time. Miss Victoria Hulse, a graduate of the class of 1891, taught during 1892 and 1893 before leaving for New Orleans to work as the "critic teacher" at the Normal and Training School (Catalog, 1904, p. 54, Biennial Report, 1892-94, p. 174). Her replacement was Mrs. Reeves, who joined the faculty in 1893, teaching English, history, and literature until her retirement in 1900 (Biennial Report, 1892-94, p. 174, Brochure, 1900, p. 13).

Stephen D. Cawthon, one of the first graduates of the normal school, came back to DeFuniak Springs after a 
year as principal in starke, Florida, to teach science and civics. He stayed at the school for ten years, while studying intermittently at the University of Virginia, and marrying Sallie Landrum, who had graduated with him in 1889 (Catalog, 1890, 1893, and Census of 1900).

Principal Felkel, born in Florida in 1850, was a school superintendent and astronomer. He taught in thirteen summer institutes in 1887 and helped to found the Florida State Teachers Association (Goulding, p. 83, FEA, p. 261). Principal Felkel stayed at the school until 1893, when he left to take over the School for the Deaf, Dumb and Blind in St. Augustine, where he died in 1897 (Condolence letter, 1897, found in Minutes).

Felkel's replacement, the Reverend walker, described himself as having thirty years' experience in the school room. He asserted that he would maintain an attitude of impartiality and cordial friendship with all his students, and that he especially loved to teach the "slow, delving, industrious plodder" (Catalog, 1893, p. 12). After leaving the normal school, he moved to Milton, Florida (Biennial Report, 1910-12, p. 313). In 1897, Cleburne Hayes became principal of the normal school. The December 1898 issue of the State Normal Messenger included a biography of Principal Hayes and studio photographs of all the 1898 faculty. Principal Hayes, born in 1866 in Tennessee, held degrees from 
Peabody Normal College and the University of Nashville. He worked as a teacher and city superintendent before assuming the principal's job in 1897 (Messenger, Dec. $1898,5: 1-2)$. Hayes and his wife lived on campus with their two little girls, and he arranged for his wife's mother, Mrs. Ann Pursley, to become the first matron of the young women's dormitory (Census, 1900, Brochure, 1900, p. 1). Principal Hayes may have left Florida, for no other record mentions him after his leaving the normal school.

Principal Hayes made some interesting changes in the school. Stephen D. Cawthon suddenly left the school in 1899, but his wife and his brother joined the faculty in 1900. Sallie, or "Tissie," became the principal of the model school, acting as critic teacher, where she stayed until the school closed in 1905. In 1904, the student alumni association reported that stephen was in Alpine, Texas, raising cattle (Catalog, 1904, p. 51, Biennial Report, 1904-06, p. 183). He died in 1909, and the next year Sallie joined the staff of Florida state Women's College in Tallahassee as Dean of the College Home. She was the "guiding spirit" of the young ladies at the college for fifteen years, counseling them in hygiene, manners, dress, and the other niceties that she and the college president believed were essential to a young woman (Sellers, p. 57). Cawthon Hall, a residential 
facility built in 1948, was named for her (sellers, p. 268).

Her brother-in-law, W. S. Cawthon, joined the normal school faculty in 1900 as well. He too was an alumni, graduating in 1890, who taught around the state for several years before enrolling at the University of Chicago, which awarded him a degree in 1905 (Catalog, 1904, p. 51, FEA, p. 258). At the normal school, he taught math until 1904 (Catalogs 1901, 1902, 1904). BY 1905, he had taken a position at the University of Florida in Lake City (Proctor, 1958, p. 526). The school brochure of 1900 described W. S. Cawthon as "alive to Florida conditions" (p. 15). He must have been, because he eventually became the state's high school inspector, and in 1922, began a fifteen year term as the state superintendent of public instruction. The stresses of guiding Florida's school system during the 1920 s and 1930 s must have required an exceptional amount of "aliveness."

Principal Hayes also hired Colonel H. P. Baya, a Virginia Military Institute graduate who later went to Bartow as superintendent of the South Florida Military College (Catalog, 1901, p. 1, Proctor, 1958, p. 135). Miss Benella Davenport joined the faculty in 1900 to teach Latin and literature (Brochure, 1900, p. 1). Miss Davenport was an active, ambitious educator. She taught 
frequently in the summer teaching institutes (Biennial Report 1896-98, p. 61, and 1898-1900, p. 137). She served twice as vice-president of the Florida state Teachers Association, and took charge of Indian clubswinging in the women's athletic association (FEA, p. 275, Catalog, 1902, p. 44). Miss Davenport, along with both stephen and W. S. Cawthon, was among the first Florida educators to be awarded a state Life certificate (Biennial Report, 1910-12, p. 183). When the school closed, Miss Davenport stayed in DeFuniak Springs and married (Biennial Report, 1910-1912, p. 183).

In 1904, H. E. Bennett became principal. He had taught at the school from 1897 to 1900 , and then worked for the Department of Education before coming back as the last principal of the normal school (Minutes, FEA, p. 256). Mr. Bennett hired his wife to supervise the men's and women's dormitories and recruited Miss Anna Chaires to run the new kindergarten department (Catalog, 1904, p. 1). Miss Chaires, from a wealthy Tallahassee family, spent well over a decade in New York studying and running modern kindergartens before returning to Florida to work at the normal school. After the school closed in 1905, Miss Chaires went to women's college in Tallahasse for a year before returning to her life in New York. She died in Sewanee, Tennessee, in 1923, where she had moved to open a kindergarten for mountain children (Hammond, 1954, 
p. 125).

While no biographical information on other faculty members could be located, all of the faculty discussed were natives of Florida or other southern states, in marked contrast with the dominance of southern schooling by northern teachers in earlier years. Mr. W. S. Cawthon and Miss Chaires earned degrees from northern institutions, but the rest of the faculty described were educated in the South. All four principals, Benella Davenport and both Cawthon brothers taught regularly in the summer institutes. There was always at least one woman on the faculty. When the faculty was enlarged after 1900, women taught Latin, literature, geography, history, biology, and manual training as well as the more traditional English, music, and kindergarten classes. The faculty in 1900 had three women, which grew to six in 1904, who taught both men and women in coeducational classrooms.

The background of the faculty was probably a factor in the willingness of conservative southern parents to allow their daughters to go away to school at DeFuniak Springs. As an example, the president of the privately operated Florida Normal School in White Springs described his own background in that school's catalog, writing that "the president's southern birth and rearing gives him an advantage among his people...he knows the difficulties, 
past and present, that beset the people. He knows their home life, and has a just sympathy with their manners, customs, and beliefs" (Florida Normal school catalog, p. 22). Undoubtedly, the same could have been said of the faculty of the normal school at DeFuniak springs.

The students

Information on the students of the normal school was located in a number of sources. The Register of students for the years between 1897 and 1905 listed four hundred and forty three students who attended the school during those years. School catalogs listed graduates from earlier years and provided other information on the students. Examination of the 1900 Census for Florida provided further information on one hundred and eighty nine students and their families. Other material appeared in the State Normal Messenger, the Biennial Reports of the Florida superintendent of education, and old county and state histories. The Alumni Association collected valuable information on graduates.

Home county of the students

One of the criticisms of the normal school was that it functioned as a local high school, an accusation that Principals Walker, Hayes, and Bennett all had to confront. The home county of all students was included 
in the Register. Of the four hundred and forty three students who attended the school between 1897 and 1905, one hundred and fifty, or 33.9 percent, were residents of Walton County. In 1898, fifty one, or 67.1 percent, of the seventy six students attending were from walton County. Thirty four students, including eight of the ten students in the top two grades were from DeFuniak. Class D, which was comparable to the preparatory, or, later, "subnormal" class, had forty seven students, twenty nine from Walton.

In 1904, Principal Bennett wrote that the normal school faculty had given "every encouragement... to strengthening" the local high school, and that in 1904, only two of the many applicants from DeFuniak springs were admitted. The rest were advised to attend the county high school. The same catalog also indicated that fifty one of the one hundred and thirty three students enrolled for the school year 1904-05 were in the "subnormal" class. In the subnormal class, thirteen students, or 25.5 percent were from Walton County, while the other thirty eight came from other parts of Florida. In 1904, thirty-one students were from DeFuniak springs, and forty-four from elsewhere in the county (Catalog, 1904, p. 10, 55). Both the increased enrollment and the smaller proportion of students coming from walton county resulted from the establishment of county scholarships in 
1901, which immediately increased the number of students from other areas of Florida.

As a comparison, the 1898 catalog from Florida Agricultural College in Lake City listed two hundred and thirty five students. One hundred and fifteen, or 49 percent, were from Columbia county where the school was located, and only sixty nine students were in the college or normal course. The great majority of students, 70.6 percent, enrolled in preparatory or business courses, so, in spite of the seven cuban students, the Lake City college functioned as a "county high school" to the same degree that the normal school did (Florida Agricultural College Catalog, 1898, p. 73).

Age of students

The normal school required that students be at least sixteen years of age before entering. A few students from DeFuniak springs entered at the age of fifteen but the mean age of the student body between 1897 and 1905 was 19.5 years. The school made a special effort to invite older students to attend. The 1888 catalog said "Do not hesitate to come to the state Normal because you think yourself too old to attend school. Students who are well matured when they enter do the best work and command prominent places upon graduating" (p. 10). Older students did indeed attend. An occasional student in his 
or her thirties, or even forties, attended for a year without staying to graduate. These students were experienced teachers taking classes to upgrade their certificates. Graduates of the school, as nearly as could be ascertained, ranged in age from their late teens to early twenties.

Gender

The student body of the normal school between 1897 and 1905 was 65 percent female. While other Florida institutions, with the exception of the south Florida Military College, admitted women, none had anything like the enrollment that the normal school did. The Florida State Normal school was definitely a school in which women could feel comfortable. They participated in activities which would not have been open to them at other "coeducational" institutions, and both men and women took the same classes, many taught by women.

The female nature of the normal schools was common around the nation at the end of the nineteenth century. State-supported normal schools had average enrollments of 263 to 285 students, so the state normal was smaller than most (Commissioner of Education 1896-97 Vol. 2 p. 1213, 1902-03 Vol. 2, p. 897). Women were 70 percent of the number of students enrolled between 1898 and 1902 in publicly supported normal schools in the United states 
(Commissioner of Education 1901-02, Vol. 2, p. 1818-19).

Graduates

During its seventeen years of operation, one hundred and twenty two students graduated from the normal school (Goulding, p. 35). Critics of Florida's institutions of higher education argued that the expense per graduate in these schools was exorbitant. However, in the case of the normal school, many students attended the school for a year or two, long enough to earn a higher grade teaching certificate, before returning to their classrooms. Principal Walker in 1895 wrote perceptively, "It may be asked, 'Why are there so few graduates?' The answer is easily found in the fact that when students complete the "C" Grade they very readily secure First Grade Certificates, which under the existing law is equivalent to a Diploma." Walker wrote that the students attending the school "primarily come from that class whose expenses are to be paid by the results of their own hard toil" and had no inducement to take the complete course, "other than their own ambition and desire for higher scholarship" (Biennial Report, 1894-96, p. 113).

Students who could only afford a year at the normal school still benefited from their studies. Presumably their own students benefited as well, and teachers with normal school preparation may have shared some of what 
they learned with fellow teachers at home. Principal Hayes wrote that sixty-seven of the ninety students of 1898-99 and sixty of the ninety-two students of 18991900, engaged in teaching in the vacation following commencement (Florida still had many counties which only had school during the summers). Hayes also said that fifty-six of those in attendance in 1898-99 and fiftythree in 1899-1900 had previously taught school (Biennial Report, 1898-1900, p. 198). At least four of the students who did not stay to graduate eventually became high school principals (Biennial Report, 1910-12, p. 259263). At least five of the short-term students, including a fifty-six year old woman from Fernandina Beach, later earned state certificates, for which it was difficult to qualify (Biennial Report, 1910-12, p. 313$317)$.

The State Normal Messenger of March 1899 wrote that "the normal students are a body of teachers. A large proportion of our young men and women make their way by teaching from three to six months of the year. Several are forced to attend on alternate years, using the summers to provide the funds to continue their studies." The article listed twenty one students in the upper grades who had taught during the summer vacation. There were eight new students who had taught previously, and the article mentioned four former students who were 
teaching.

The school made an effort to assist alumni. The 1890 catalog wrote that of 1889 graduating class, three were elected principals of "prominent city schools" in Florida, while the others occupied less prominent places, "but all held lucrative positions and did most satisfactory work" (p. 14). Normal school principals referred students to prospective employers, announcing to the public that "students and graduates may often be secured as teachers by writing to the Principal, who will conscientously recommend such as, in his opinion, are deserving. Many of those, even in the lowest grades, as their experience has proven, are capable of doing good service in the common schools" (Catalog, 1898, p. 18).

In 1898, the normal school Alumni Association established a "Mutual Aid Department," which would assist members in locating employment in the schools. To this end, the Association advertised in the Normal Messenger, "Do you want a competent teacher? If so, write to Secretary of the State Normal Alumni

Association, Fla. None but the best recommended." The secretary kept a record of members who notified him that they were seeking a position, and "upon receiving information of such vacancy shall immediately notify the member to apply for it, giving him all the information at his command which would help secure the 
position." For

these services, the secretary received an annual salary of 25 cents for each member not in arrears and half of all fees collected from members who secured positions through the Mutual Aid Department. Stephen Cawthon was the first secretary of the alumni association, and job seekers could write to him for assistance (By-Laws of the Alumni Association, July 1898).

The alumni association also kept in touch with former graduates. The March 1899 Messenger listed the whereabouts of a number of graduates. They included a state representative, a county superintendent, six teachers, five principals, a lawyer, a state senator, a Baptist minister, and the critic teacher of the New Orleans City Normal School (p. 6:1).

Jurgen Herbst argued that the normal schools of the nineteenth century failed in their mission of training teachers for the common schools, and were used instead as a way to obtain a higher education before going on to other professions (Herbst, 1989, p. 219-221). In the case of the Florida state Normal College, only fragmentary evidence exists, and what evidence there is could be used to argue in favor of, or againt, Herbst's assertion. In 1903, the alumni association compiled a complete list of the whereabouts of graduates of the State Normal School, included as Appendix A. The 
graduates had scattered across Florida, some even going north. Of seventy eight graduates listed, twenty nine were teaching or otherwise working in the schools. Many of the women had married and were not working. Other graduates included lawyers, businessmen, a doctor and a medical student, a musician, a tax collector, and two students at Peabody (Catalog, 1904, p. 51-54). One graduate, Edwin McMullen, almost did not graduate from the normal school because of his low grade in algebra (Minutes). He later graduated from Peabody and had a distinguished career in Florida education (FEA, p. 268). One graduate, W. S. Cawthon, became state superintendent of education. Another graduate, Joe Lockey, eventually became a professor at Peabody, and then taught at the University of California (FEA, p. 266). Charles Andrews became a photographer, and then a judge (McEwen, taped interview, Cutler, p. 233). Will Yon beame a state auditor (Cutler). Sallie Landrum Cawthon ran the model school before becoming one of the best remembered personalities of the early years of the florida state College for Women. Missouri Cawthon and Christian Gillis never married, but taught for many years. One of the women graduates married and owned a successful dress shop with her sisters (Mock, personal correspondence, March 4, 1996). Stuart Knox Gillis became a circuit judge in Walton County, Fannie Lou Cawthon taught high school, and 
Maud Saunders taught and had an elementary school named for her. Sallie Cawthon's sister Lonnie Landrum taught, while another sister, Callie, became one of the first women pharmacists in the United states (McEwen, taped interview).

In 1912, the Biennial Report listed every person, living or dead, who held a Florida state teaching certificate. Comparison to a list of all known students of the normal school, which unfortunately does not include students between 1890 and 1897 who attended but did not stay to graduate, showed that twenty three students earned a state certificate, and twelve earned a life certificate. These certificates were extremely difficult to earn. Among other Florida certificate holders were state and county superintendents, principals, and college presidents, which indicates how prestigious the certificates were.

The Census of 1900

One hundred and eighty nine of the four hundred and forty three students enrolled in the normal school between 1897 and 1905 were located on the Florida Census of 1900 .

Family size

As seen on Table 1 , the mean number of siblings 
living at home for the students located on the census was 3.91 , so the students came from homes which had an average of five children. The largest number of siblings reported was eight.

Interestingly, eighty four of the women students, or 62.7 percent, were the oldest daughter in their families, with younger brothers and sisters living at home (Table 2 ). Instead of being kept at home to help their mothers with the children, these young women were sent to school to prepare for a profession. Their mothers saw education as a way for their daughters to secure their futures and were willing to sacrifice badly needed help to do so.

Siblings at school

In her study of antebellum women's education in the South, Farnham observed that students often attended school with siblings or cousins, which reduced homesickness and

reassured parents (p. 123). As Table 3 indicates, of the students identified on the census, eighty eight, or 46.6 percent, had siblings attending school between 1897 and 1905. Table 4 demonstrates that 45.5 percent of the female students attending between 1897 and 1905 had siblings attending school. More may have had siblings 
Table 1

Family size
Number of siblings the students had

Siblings Frequency Percent Percent Percent

\begin{tabular}{|c|c|c|c|c|}
\hline .00 & 4 & 2.1 & 2.1 & 2.1 \\
\hline 1.00 & 19 & 10.1 & 10.1 & 12.2 \\
\hline 2.00 & 23 & 12.2 & 12.2 & 24.3 \\
\hline 3.00 & 33 & 17.5 & 17.5 & 41.8 \\
\hline 4.00 & 37 & 19.6 & 19.6 & 61.4 \\
\hline $\begin{array}{l}5.00 \\
6.00\end{array}$ & $\begin{array}{l}27 \\
35\end{array}$ & $\begin{array}{l}14.3 \\
18.5\end{array}$ & $\begin{array}{l}14.3 \\
18.5\end{array}$ & $\begin{array}{l}75.7 \\
94 . ?\end{array}$ \\
\hline $\begin{array}{l}7.00 \\
8.00\end{array}$ & 6 & 3.2 & 3.2 & 97.4 \\
\hline & 5 & 2.6 & 2.6 & 100.0 \\
\hline Tota & 189 & 100.0 & 100.0 & \\
\hline
\end{tabular}

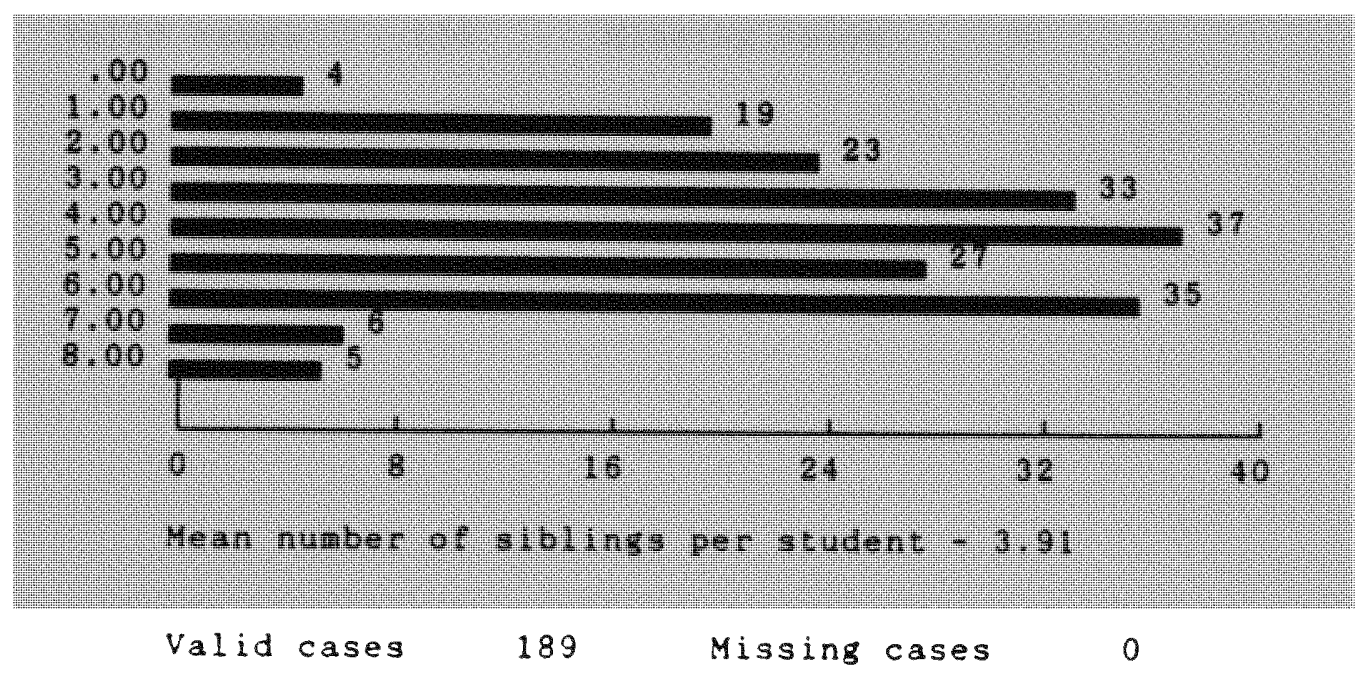




\section{Table 2}

Women students who were the oldest daughter in their families

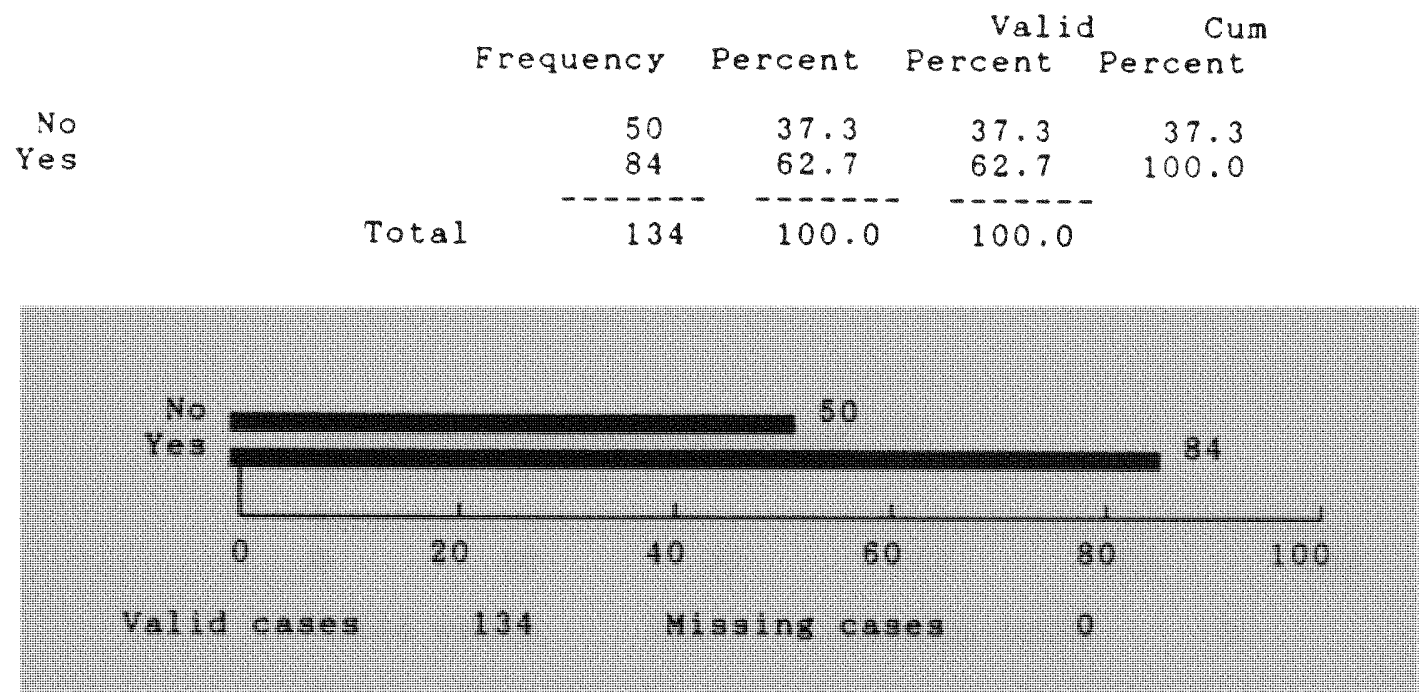




\section{Table 2}

Women students who were the oldest daughter in their families

No

Yes

$$
\text { Frequency Percent Percent Percent }
$$

\begin{tabular}{|c|c|c|c|}
\hline & $\begin{array}{l}50 \\
84\end{array}$ & $\begin{array}{l}37.3 \\
62.7\end{array}$ & $\begin{array}{l}37.3 \\
62.7\end{array}$ \\
\hline & $---m-n$ & $-----\cdots$ & $m-\cdots$ \\
\hline Total & 134 & 100.0 & 100.0 \\
\hline
\end{tabular}

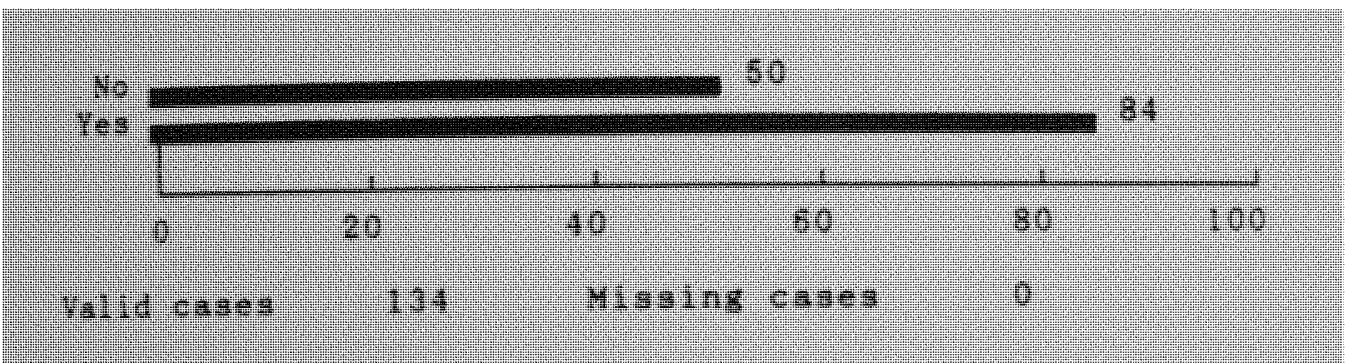


Table 4

Women students with siblings who attended the normal school between 1897 and 1905

$\begin{array}{rrrrr} & \text { Frequency } & \text { Percent } & \begin{array}{r}\text { Valid } \\ \text { Percent }\end{array} & \begin{array}{c}\text { Cum } \\ \text { Percent }\end{array} \\ \text { No } & & & & \\ \text { Yes } & 61 & 44.5 & 54.5 & 54.5 \\ \text { Total } & 134 & 100.0 & 100.0 & \end{array}$

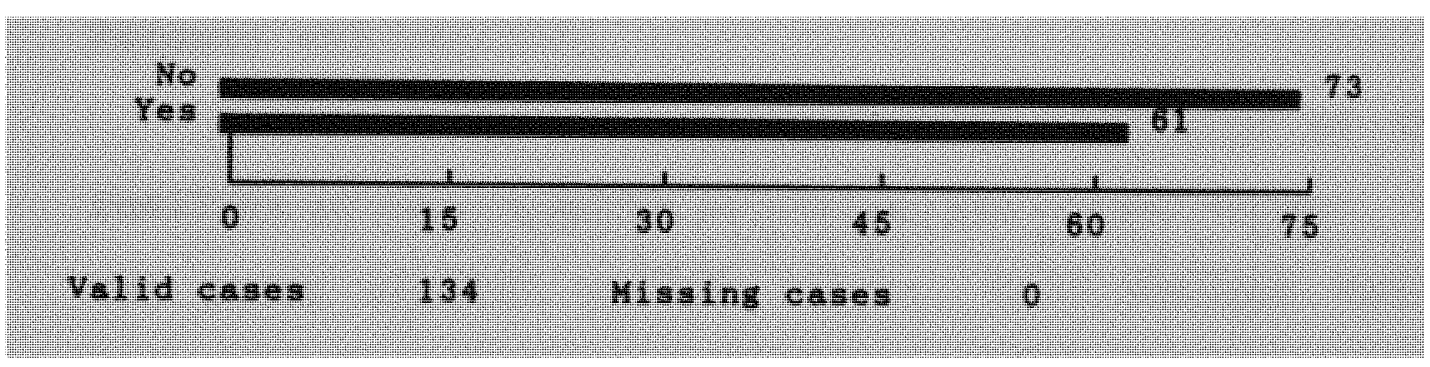


who attended in earlier years for which records were not available. Cousinship can not be verified from the census materials, but it can be inferred given the southern tradition of naming children with a mother's or grandmother's maiden name. It is likely that many of the students had cousins attending the school, but the number could not be determined.

Parents and families

Tables 5 and 6 illustrate the stability of the families of the students attending the normal school. Of the group located on the census, 85.2 percent had a father still living in 1900, and 94.2 percent had a mother living (Table. Early death was a fact of life in Florida at the turn of the century. The fact that so many students had one or both parents still living meant that they had more than usually stable families. Very likely, those families had been prosperous enough to afford better housing, sanitation, food, and medical care.

White Floridians over the age of ten in 1900 had a 6.4 percent illiteracy rate, which was quite low for the South. The parents of the students at the normal school were much more literate than that. Of the fathers who were alive in 1900, all were literate. Of the mothers, only three were illiterate (Tables 7 and 8 ). 
Table 5

Students whose father was living in 1900

$\begin{array}{crrrr} & \text { Frequency } & \text { Percent } & \begin{array}{c}\text { Valid } \\ \text { Percent }\end{array} & \begin{array}{c}\text { Cum } \\ \text { Percent }\end{array} \\ \text { Deceased } & 28 & 14.8 & 14.8 & 14.8 \\ \text { Living } & 161 & 85.2 & 85.2 & 100.0 \\ \text { Total } & 189 & 100.0 & 100.0 & \end{array}$

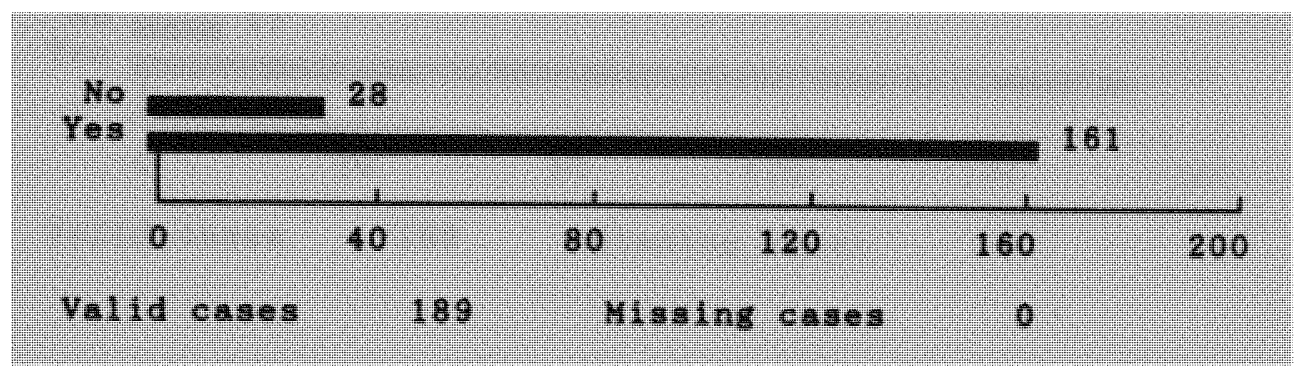


Table 6
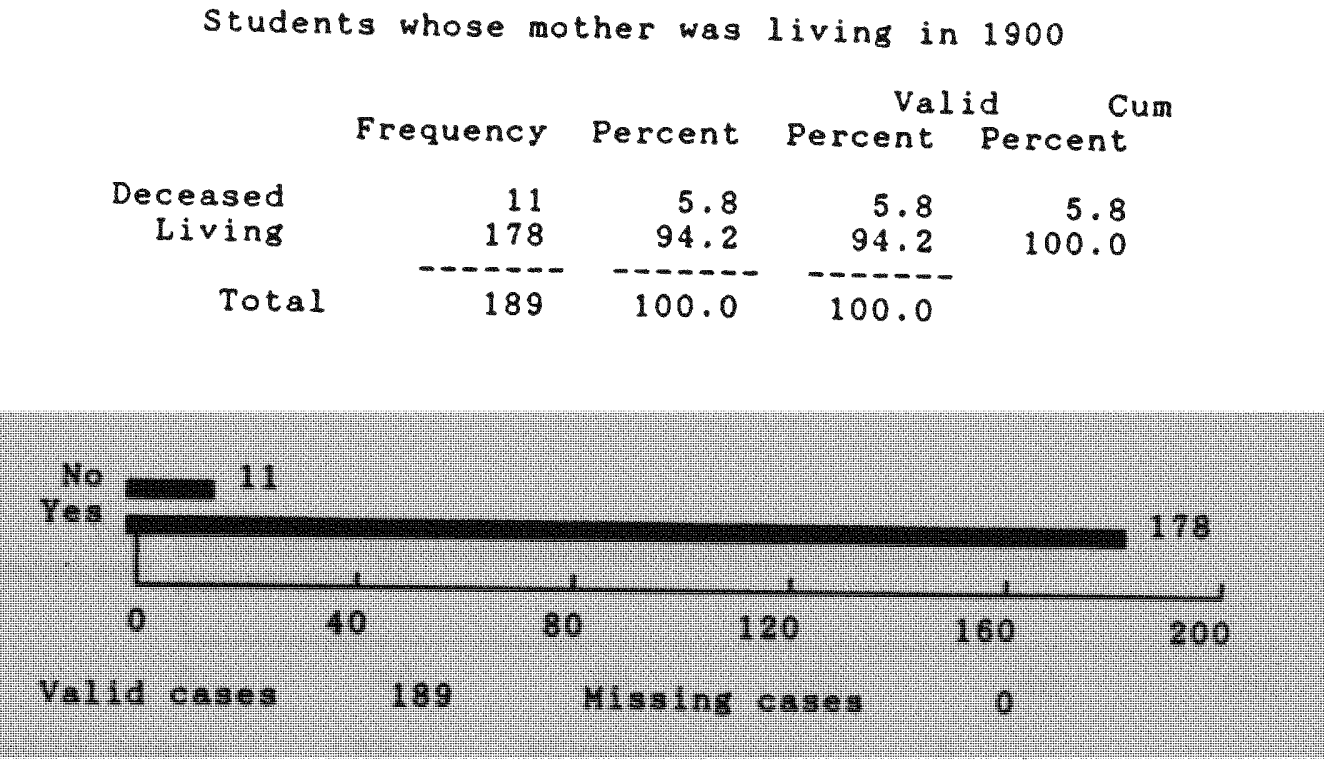
Table 7

\section{Students whose father was literate (fathers living in 1900)}

$\begin{array}{crrrr} & \text { Frequency } & \text { Percent } & \begin{array}{r}\text { Valid } \\ \text { Percent }\end{array} & \begin{array}{r}\text { Cum } \\ \text { Percent }\end{array} \\ \text { Father deceased } & 161 & 85.2 & 85.2 & 85.2 \\ \text { Total } & 28 & 14.8 & 14.8 & 100.0 \\ & 189 & 100.0 & 100.0 & \end{array}$

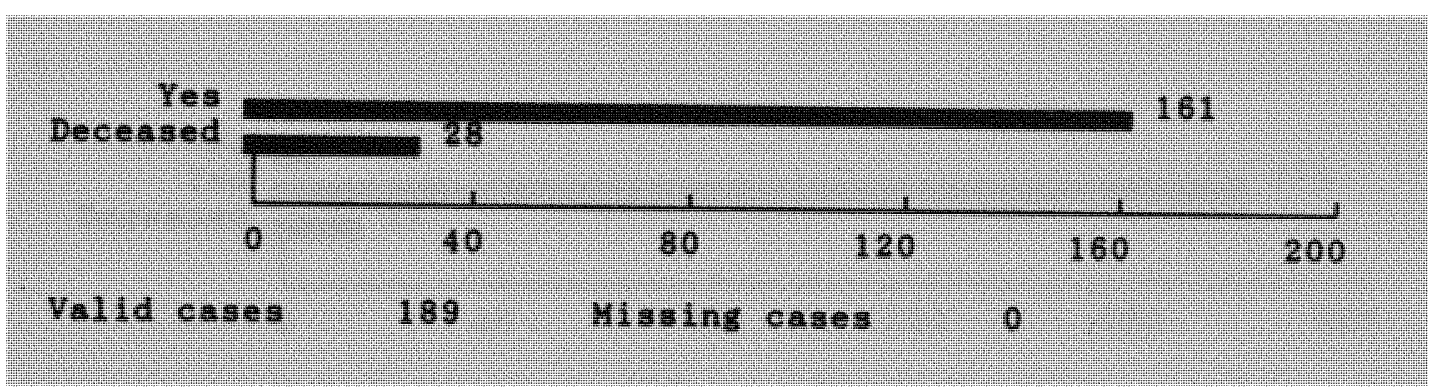


Table 8

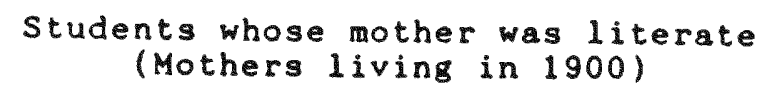

$\begin{array}{rrrrr} & \text { Frequency } & \text { Percent } & \begin{array}{c}\text { Valid } \\ \text { Percent }\end{array} & \begin{array}{c}\text { Cum } \\ \text { Percent }\end{array} \\ \text { Illiterate } & 3 & 1.6 & 1.6 & 1.6 \\ \text { Literate } & 175 & 92.6 & 92.6 & 94.2 \\ \text { Mother deceased } & 11 & 5.8 & 5.8 & 100.0 \\ \text { Total } & -189 & 100.0 & 100.0 & \end{array}$

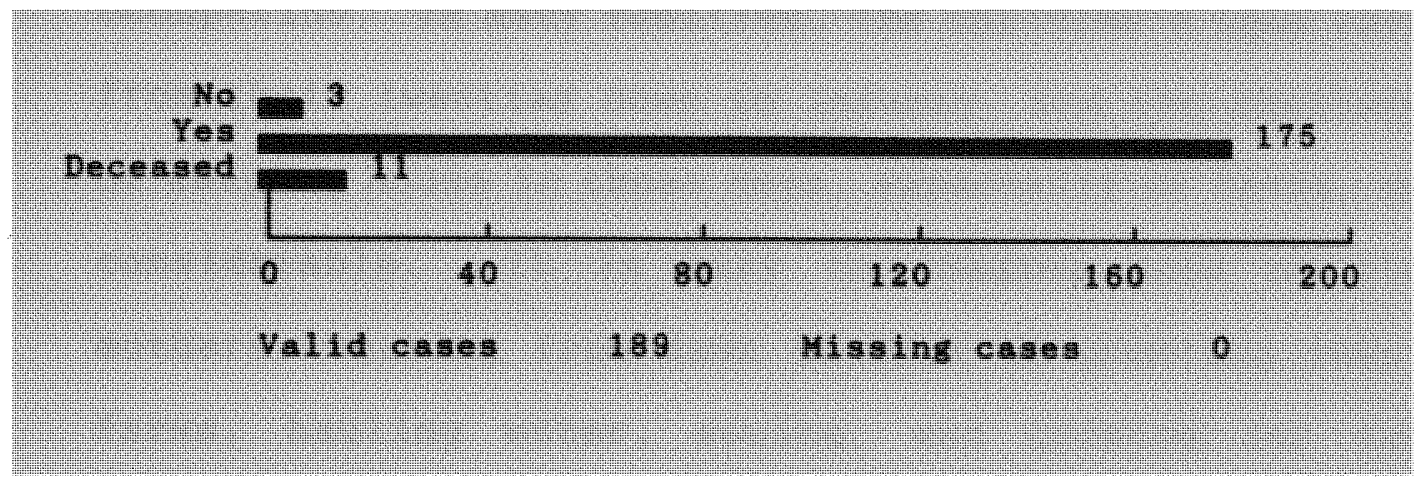


The families located on the census were very much of the middle-class. Table 9 lists the father's occupations, which were classified as farmers, day laborers, skilled tradesmen, such as factory foremen and carpenters, merchants, and professionals, including ministers, teachers, attorneys, physicians, and managers.

The great majority of the mothers living in 1900, 86.8 percent, listed "keeping house" as their primary occupation. In many families, the children's ages ranged from their twenties down to infancy, and the challenges of keeping house in those days, especially on farms, were considerable. It is easy to imagine some of those mothers, working from dawn to dark at grueling jobs on farms, hauling water, sewing, and cooking for large families, sending a much loved oldest daughter off to school. Of the mothers who listed other occupations, one was a seamstress, eight took in boarders, and six, all widows, farmed with the assistance of their sons.

At the turn of the century, half the men in Florida worked in agriculture. On the census, the fathers of 40.7 percent of the students were identified as primarily engaged in farming. The fathers of the students were more representative of the new "urban" middle-class of the south. A cumulative total of 43.9 percent of the fathers living in 1900 were identified as professionals, 
Table 9

Father's occupation in 1900

\begin{tabular}{|c|c|c|c|c|}
\hline & Frequency & Percent & $\begin{array}{l}\text { Valid } \\
\text { Percent }\end{array}$ & $\begin{array}{c}\text { Cum } \\
\text { Percent }\end{array}$ \\
\hline $\begin{array}{r}\text { Farmer } \\
\text { Merchant } \\
\text { Professional } \\
\text { Day laborer } \\
\text { Deceased } \\
\text { killed trades }\end{array}$ & $\begin{array}{r}77 \\
10 \\
51 \\
6 \\
23 \\
22\end{array}$ & $\begin{array}{r}40.7 \\
5.3 \\
27.0 \\
3.2 \\
12.2 \\
11.6\end{array}$ & $\begin{array}{r}40.7 \\
5.3 \\
27.0 \\
3.2 \\
12.2 \\
11.6\end{array}$ & $\begin{array}{r}40.7 \\
46.0 \\
73.0 \\
76.2 \\
88.4 \\
100.0\end{array}$ \\
\hline Total & 189 & 100.0 & 100.0 & \\
\hline
\end{tabular}

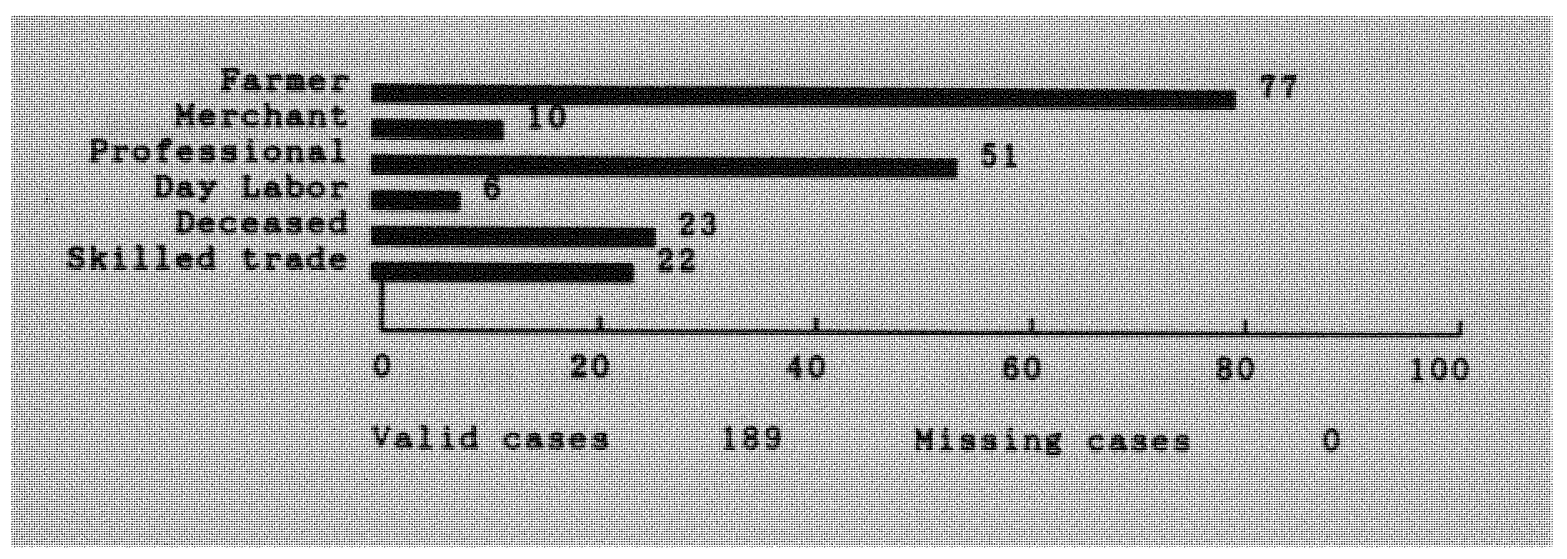


Table 10

$\begin{array}{crrrr}\text { Mother's occupation in } 1900 \\ \text { Frequency } & \text { Percent } & \begin{array}{r}\text { Valid } \\ \text { Percent }\end{array} & \begin{array}{r}\text { Cum } \\ \text { Percent }\end{array} \\ \text { Keeping house } & 164 & 86.8 & 86.8 & 86.8 \\ \text { Seamstress } & 1 & .5 & .5 & 87.3 \\ \text { Boarding house } & 8 & 4.2 & 4.2 & 91.5 \\ \text { Farming } & 6 & 3.2 & 3.2 & 94.7 \\ \text { Deceased } & 10 & 5.3 & 5.3 & 100.0 \\ \text { Total } & 189 & 100.0 & 100.0 & \end{array}$

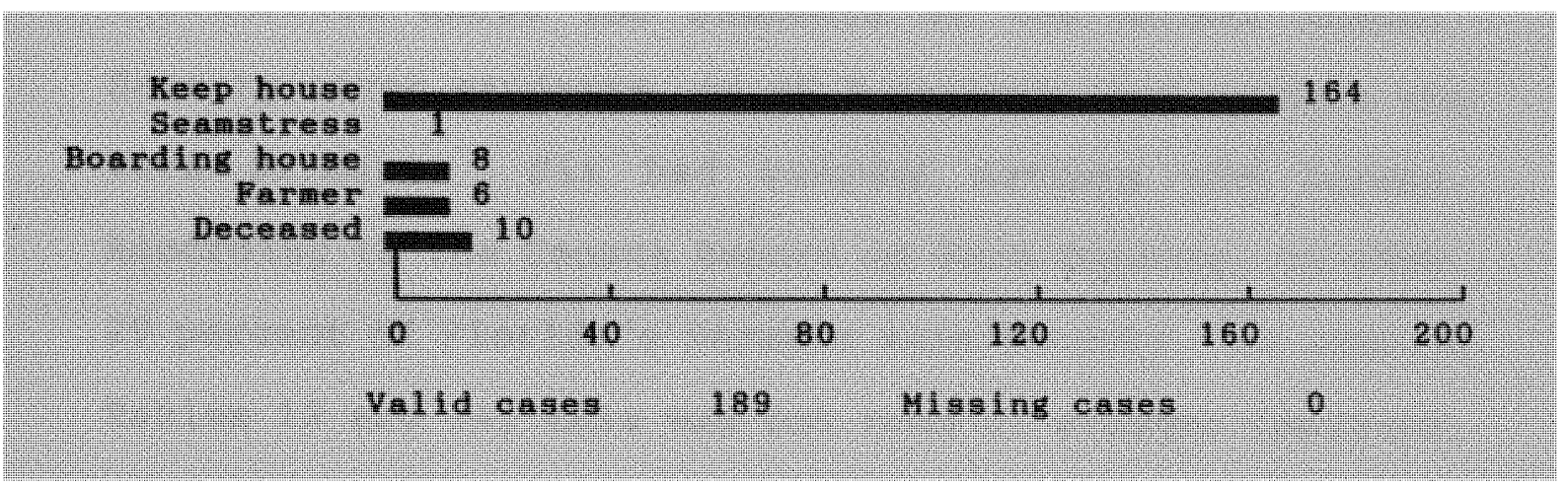


businessmen, or skilled tradesmen.

The families of the women students (Tables 11 and 12) were even more "town" oriented than the group taken as a whole. Of the women, 34.3 percent had fathers whose main occupation was farming, and 49.2 percent had fathers who earned a living in towns. Of 134 women found on the census, 14 had mothers 1 isted on the census as having an occupation other than "keeping house."

Tables 13 and 14 illustrate an important distinction about the students at the normal school. Seventy seven students, or 40.7 percent, had fathers who were farmers. Six had widowed mothers who farmed. According to the Census Report on Farm Tenancy, in 1900, 29 percent of Florida's farmers were tenants. As seen on Tables 13 and 14, this was not true of student families. only one student, whose mother was widowed and farming, lived on a rented farm. The other eighty two came from families that owned their farms outright, with no mortgage.

New villages and towns emerged in every corner of the South, either growing rapidly or sending their residents on to other towns and cities (Ayers, p. 19-20). In Florida, immigration from other states was accompanied by movement within the state. After the great freeze of 1895, and the opening of the southern part of the state after the railroads were built, many floridians moved on 


\section{Table 11}

Father's occupation in 1900 - Women students

\begin{tabular}{|c|c|c|c|c|}
\hline & Frequency & Percent & $\begin{array}{l}\text { Valid } \\
\text { Percent }\end{array}$ & $\begin{array}{r}\text { Cun } \\
\text { Percent }\end{array}$ \\
\hline $\begin{array}{r}\text { Farmer } \\
\text { Merchant } \\
\text { Professional } \\
\text { Day laborer } \\
\text { Deceased } \\
\text { Skilled trades }\end{array}$ & $\begin{array}{r}46 \\
9 \\
39 \\
2 \\
20 \\
18\end{array}$ & $\begin{array}{r}34.3 \\
6.7 \\
29.1 \\
1.5 \\
14.9 \\
13.4\end{array}$ & $\begin{array}{r}34.3 \\
6.7 \\
29.1 \\
1.5 \\
14.9 \\
13.4\end{array}$ & $\begin{array}{r}34.3 \\
41.0 \\
70.1 \\
71.6 \\
86.6 \\
100.0\end{array}$ \\
\hline Total & 134 & 100.0 & 100.0 & \\
\hline
\end{tabular}

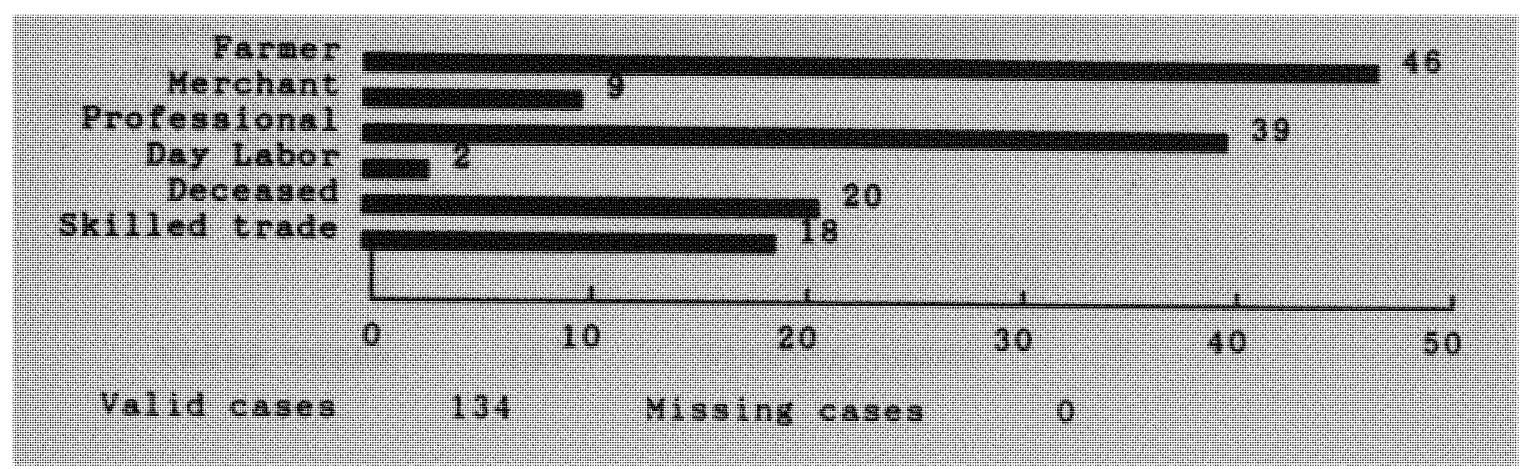


Table 12

Mother's occupation in 1900 - Women students

\begin{tabular}{|c|c|c|c|c|}
\hline & Frequency & Percent & $\begin{array}{r}\text { Valid } \\
\text { Percent }\end{array}$ & $\begin{array}{l}\text { Cum } \\
\text { Percent }\end{array}$ \\
\hline $\begin{array}{r}\text { Keeping house } \\
\text { Seamstress } \\
\text { Boarding house } \\
\text { Farming } \\
\text { Deceased }\end{array}$ & $\begin{array}{r}112 \\
1 \\
8 \\
5 \\
8\end{array}$ & $\begin{array}{r}83.6 \\
.7 \\
6.0 \\
3.7 \\
6.0\end{array}$ & $\begin{array}{r}83.6 \\
.7 \\
6.0 \\
3.7 \\
6.0\end{array}$ & $\begin{array}{r}83.6 \\
84.3 \\
90.3 \\
94.0 \\
100.0\end{array}$ \\
\hline & 134 & 100.0 & 100.0 & \\
\hline
\end{tabular}

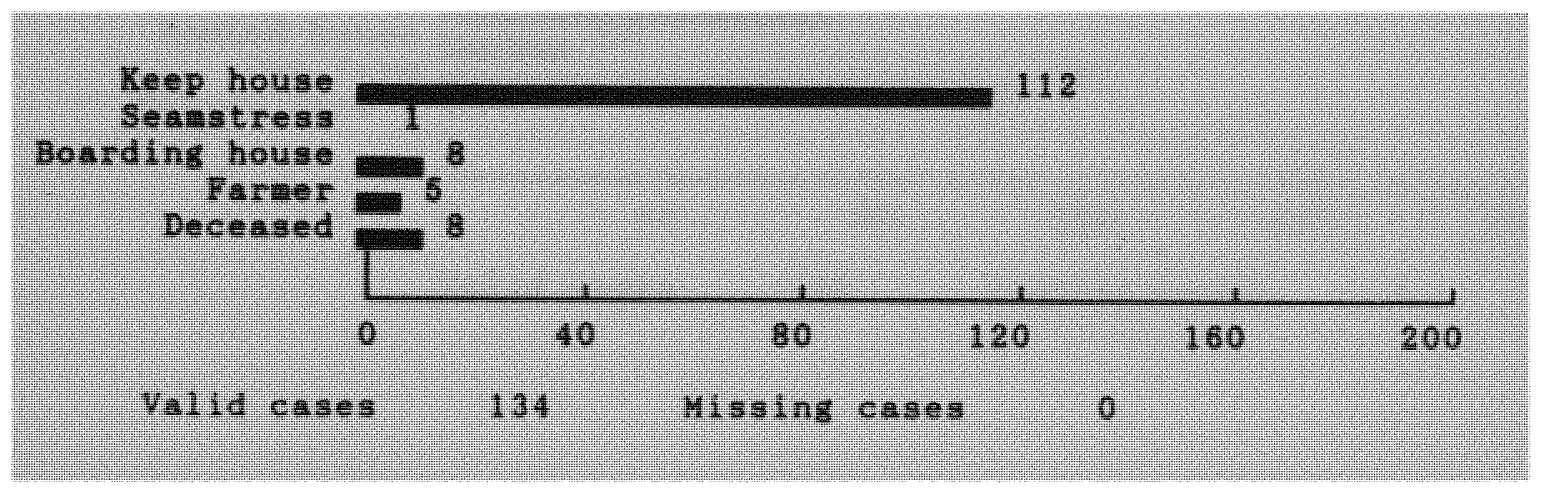


Table 13

Student's family home in 1900

\begin{tabular}{|c|c|c|c|c|}
\hline & Frequency & Percent & $\begin{array}{l}\text { Valid } \\
\text { Percent }\end{array}$ & $\begin{array}{r}\text { Cum } \\
\text { Percent }\end{array}$ \\
\hline $\begin{array}{r}\text { Family owned house } \\
\text { Rented house } \\
\text { Family owned farm } \\
\text { Rented farm }\end{array}$ & $\begin{array}{r}67 \\
19 \\
102 \\
1\end{array}$ & $\begin{array}{r}35.4 \\
10.1 \\
54.0 \\
.5\end{array}$ & $\begin{array}{r}35.4 \\
10.1 \\
54.0 \\
.5\end{array}$ & $\begin{array}{r}35.4 \\
45.5 \\
99.5 \\
100.0\end{array}$ \\
\hline Total & 189 & 100. & 100.0 & \\
\hline
\end{tabular}

Own houge Rented house Oun faren Rented farm

\section{7}

19

102

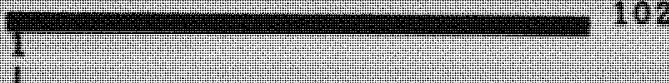

40

BO

120

160

200 
Table 14

Family home in 1900 - Women Students

$\begin{array}{rrrrr} & \text { Frequency } & \text { Percent } & \begin{array}{r}\text { Valid } \\ \text { Percent }\end{array} & \begin{array}{r}\text { Cum } \\ \text { Percent }\end{array} \\ \text { Family owned house } & 49 & 36.6 & 36.6 & 36.6 \\ \text { Rented house } & 17 & 12.7 & 12.7 & 49.3 \\ \text { Family owned farm } & 67 & 50.0 & 50.0 & 99.3 \\ \text { Rented farm } & 1 & .7 & .7 & 100.0 \\ \text { Total } & 134 & 100.0 & 100.0 & \end{array}$

Owned house Rented house

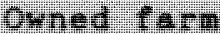
Rented farm

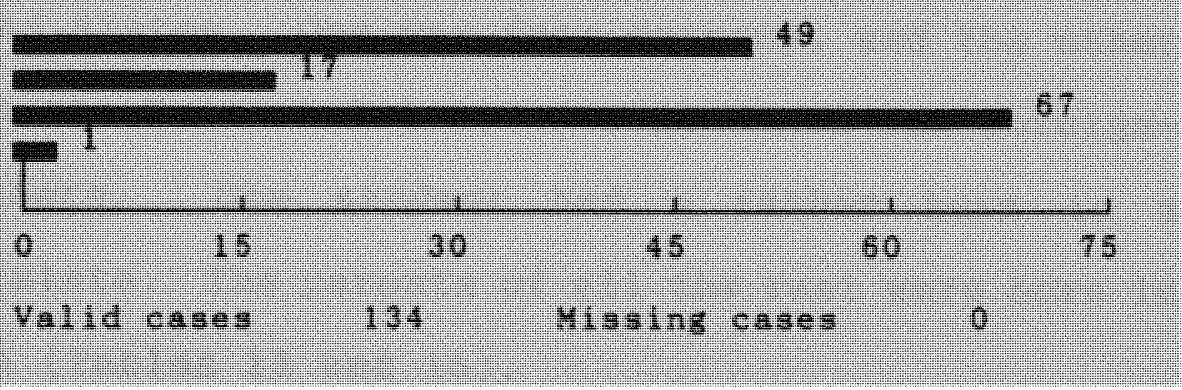


to other regions. The students who lived in houses in the towns reflected the restless nature of the times. Fully 35.4 percent lived in rented homes (Table 13).

Lotus Coffman in 1911 observed that many teachers, especially in the cities, were the second-generation children of immigrants (p. 55). The South had received few immigrants throughout the nineteenth century, and this was reflected in the student body. A number of students from walton County had grandparents born in Scotland, but only five students had fathers born outside the United States. One was from Germany, and the other four from the British Isles. Two students had foreignborn mothers. One student had a father born in a northern state. The parents of all the rest were born in the South (Tables 15 and 16).

Principal walker said in 1895 that the student body was composed to a large degree of students who had to earn their own way in the world. Tables 17 and 18 report the occupations of the students at the time the census was taken. Of the students located in the 1900 census, 72 percent listed their occupation as "student." A large number of them were still in the common schools or county high schools. Of the fifty three students who were employed in 1900, forty two were teachers (thirty one were women). The women reported no other occupations, but the several of the men students also worked as farm 
Table 15

Father's place of birth

$\begin{array}{rcccc} & \text { Frequency } & \text { Percent } & \begin{array}{c}\text { Valid } \\ \text { Percent }\end{array} & \begin{array}{c}\text { Cun } \\ \text { Percent }\end{array} \\ \text { Southern state } & 183 & 96.8 & 96.8 & 96.8 \\ \text { Born in Europe } & 5 & 2.6 & 2.6 & 99.5 \\ \text { Northern state } & 1 & .5 & .5 & 100.0 \\ \text { Total } & 189 & 100.0 & 100.0 & \end{array}$

Born in South Eorn in Burgpe Born in North

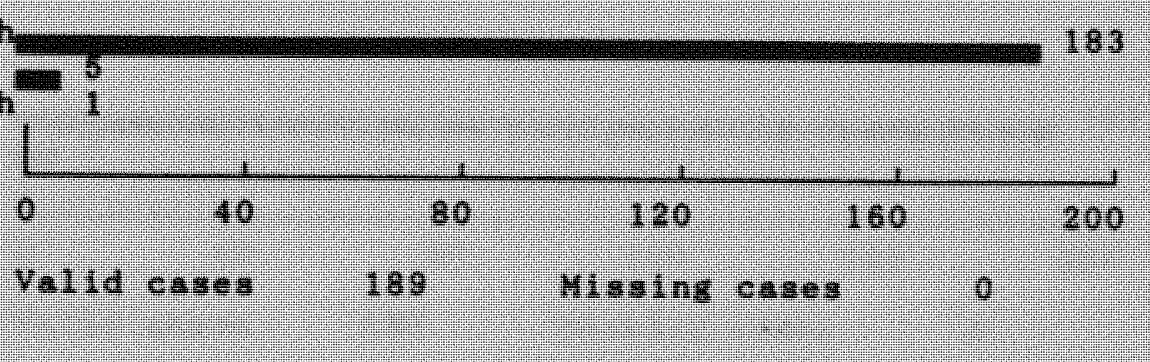


Table 16

Mother's place of birth

$\begin{array}{ccccc} & \text { Frequency } & \text { Percent } & \begin{array}{c}\text { Valid } \\ \text { Percent }\end{array} & \begin{array}{c}\text { Cum } \\ \text { Percent }\end{array} \\ \text { Southern U.S. } & 187 & 98.9 & 98.9 & 98.9 \\ \text { Europe } & 2 & 1.1 & 1.1 & 100.0 \\ \text { Total } & 189 & 100.0 & 100.0 & \end{array}$

Southern U.S. Europe

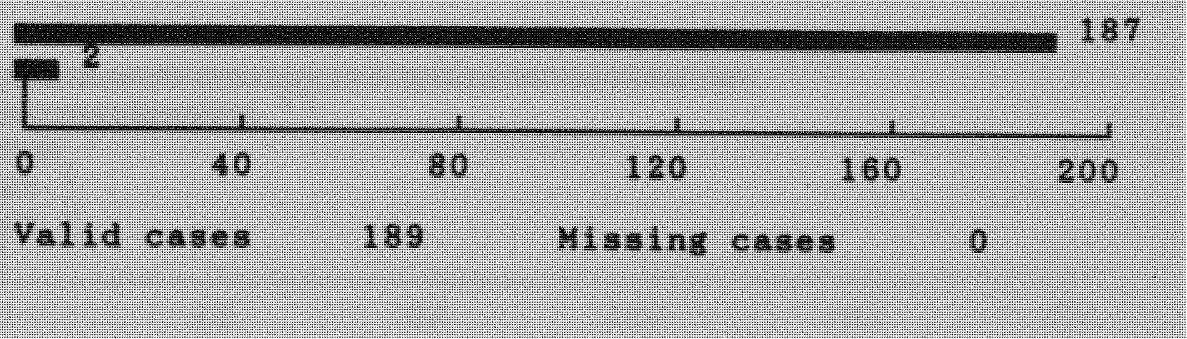


Table 17

Student occupations in 1900

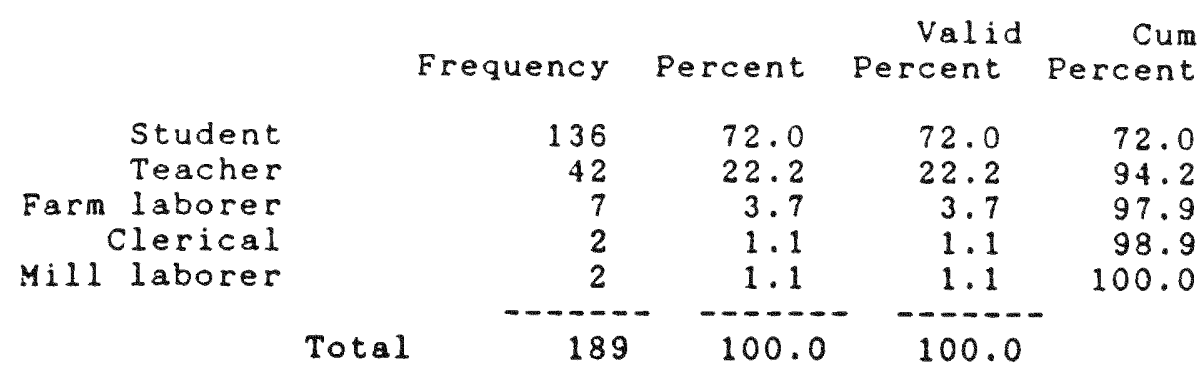

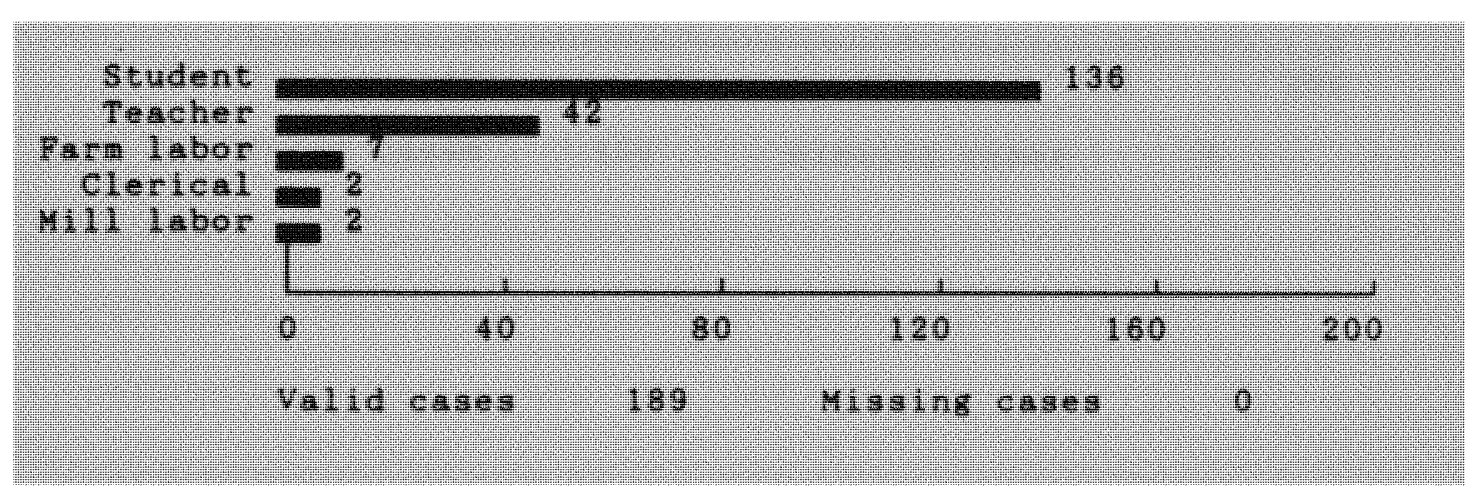


Table 18

Occupations in 1900 of women students Frequency Percent Percent Percent

$\begin{array}{lrrrr}\text { Student } & 103 & 76.9 & 76.9 & 76.9 \\ \text { Teacher } & 31 & 23.1 & 23.1 & 100.0 \\ & & 134 & 100.0 & 100.0\end{array}$

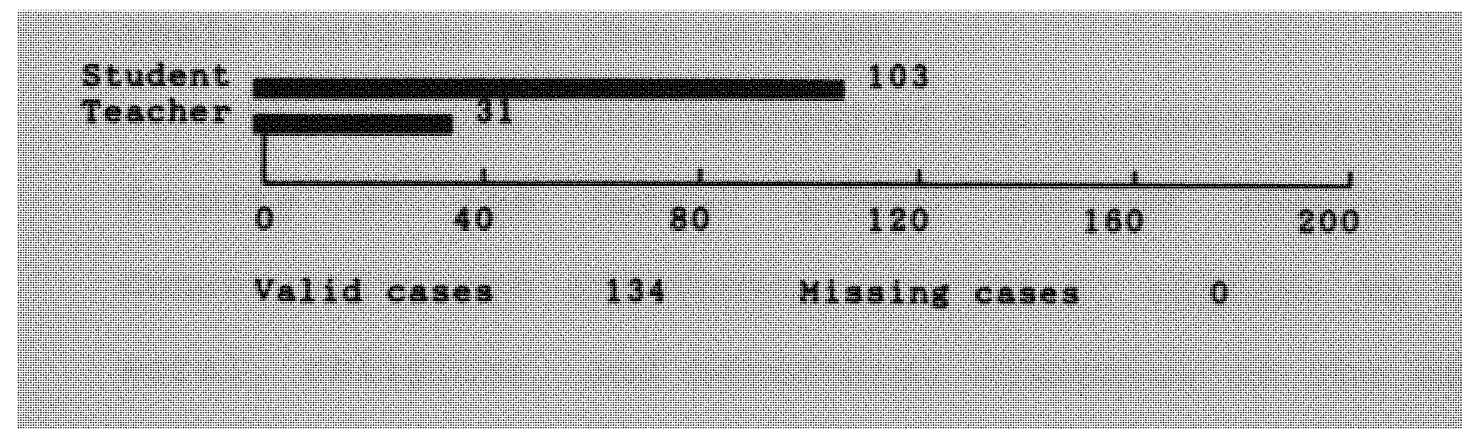


laborers on their family farms, two had clerical jobs, and two of the young men worked in a mill. Certainly a large number of students were paying their own way, and others greatly needed the assistance provided by the scholarship program. However, the large proportion of students located on the 1900 census who listed their primary occupation as "student," indicated that it was probable that they were receiving at least some help from their families as they studied.

The picture which emerged of the students and of the faculty of the normal school was of essentially conservative men and women, willing to conform to the moral, religious, and behavioral standards of the day. Still, they, or perhaps a mother or father, were ambitious and a bit daring. After all, it was unusual for a young woman to be allowed to go away to school at all. The women teaching at the school had been educated as professionals and certainly were unusual for their time. The students located on the census came from stable middle-class families, with parents who were literate. Many had brothers, sisters, and probably cousins at school. While relatively few students stayed to graduate, others did improve their educations and continued teaching in the common schools. 


\section{Discussion}

The study of the Florida state Normal College at DeFuniak springs was conceptualized as a case study which, in addition to contributing to our knowledge of this particular institution, would add to our understanding of the development of Florida's system of higher education, of the roles of women, of American normal schools, and of the progressive educational movement in the New South. A number of questions guided the research.

1. What factors led to the founding of the Florida State Normal College?

2. What were the social, economic, and academic characteristics of the students? How were they comparable to other students enrolled in institutions of higher education during this time period?

3. What were the fundamental aspects of school life at the Florida State Normal College?

4. What role did the presence of these students and this institution play in the development of a modern system of education in Florida?

5. Is it possible to determine what became of these students after college? If so, what was the impact of their education at the college on their future activities?

6. How did the institution and its students reflect 
the dominant trends in American education? What can the study of the Florida state Normal college add to our understanding of gender roles, education, and progressivism in the New South?

What factors led to the founding of the Florida State Normal College? As discussed, Florida was backward in education at every level. The school, and the normal school at Tallahassee for black students, were established in an effort to raise the standards of Florida teachers at the same time that the state struggled to develop a comprehensive graded system of common schools and to standardize requirements for teachers. The location of the school at DeFuniak springs can be attributed to a large degree to the incentives offered by W. D. Chipley and his associates, including the use of the Chautauqua buildings and bargain railroad fares. The state teacher's institutes held at DeFuniak Springs during Chautauqua season attracted educators from around the state, and the population of Florida in 1887 when the school opened was still concentrated to a large degree in the northern part of the state. Legislators did not anticipate the rapid growth of the southern and central portions of the state in the $1890 \mathrm{~s}$.

What were the social, economic, and academic characteristics of the students? How were they comparable to other students enrolled in institutions of 
higher education during this time period? Use of the census materials and other documents made it possible to describe the students as the children of late victorianera, literate, middle-class, native-born southerners. The students were Protestants, and religion was very much a part of their lives. They demonstrated self-control and adherence to the social codes of the day. Most had stable families, with both parents living. Many lived on farms, but a substantial number of the students came from homes located in cities and towns. Interestingly, a large number of the women students were the oldest daughter in their families. Many students had siblings, neighbors, and cousins attending the school and it is easy to speculate that they or their parents wanted them to go to school with someone from home. No similar data on the students of other institutions was located during the course of the study, so comparisons were not possible, although it seems reasonable that students in other schools would have had similar middle-class backgrounds .

What were the fundamental aspects of school life at the Florida state Normal College? The curriculum, dormitories, and organizations were comparable to those of normal schools elsewhere in the United States. The school catalogs include lists of the textbooks in use at the normal school, which were standard texts published by 
major national house. During the first years of operation, the school had a somewhat eccentric curriculum, but after the state of Florida established new requirements for teacher certification in the 1890 s the school rapidly professionalized. The students spent over twenty hours a week in the classroom, in addition to time in the model teaching school, until 1904. After 1900, enhanced legislative financial support of its operations allowed the school to acquire good facilities and a qualified staff. Students were required to do regular practice teaching, and had the benefit of a greatly expanded library. The experience of the students of the normal schools was truly coeducational, as students shared both classrooms and outside activities, and the women students at the normal school were less restricted than were later students at the Florida state College for Women.

During the time that the normal school was open, students in more prominent universities and colleges were obsessed with extracurricular life and the "Gentleman's C" was an accepted standard of achievement. This sort of campus life appears not to have developed at the normal school. Many students were already working, and, after 1901, forty five students every year were scholarship students. Most students did not stay to graduate, intercollegiate athletics were not encouraged, and there is no 
record of any fraternity, sorority, or secret society on campus. The normal schools were not only coeducational, but were more egalitarian than other institutions of higher learning in those times.

Students at the normal school were fortunate to attend school in a pretty, healthful town that was pleased to have them there. They participated in local church activities, and had the added fun of the Florida Chautauqua programs.

What role did the presence of these students and this institution play in the development of a modern system of education in Florida? This was one of the most important aspects of this study, because relatively little research has been done on the early development of higher education in Florida. Before the normal school opened, only two seminaries located in Gainesville and Tallahassee and the new agricultural college in Lake City offered higher education to white Floridians. In 1887, the normal school and its sister institution, the normal school for black students, became the first state institutions dedicated only to the training of teachers. By 1905, there were seven publicly supported institutions in Florida: the Florida state College at Tallahassee, the two normal schools, the University of Florida in Lake City, the South Florida Military Institute in Bartow, the Institute for the Deaf, Dumb, and Blind in st. Augustine, 
and the Agricultural Institute at Kissimmee, which had not yet opened. The Lake City institution had been coeducational until 1903, when it adopted a "men only" policy. The other institutions, with the exception of the military school, remained coeducational, al though the normal school was certainly the institution with the greatest number of women among the student body.

The Buckman Act of 1905 not only ended coeducation in Florida, but closed the only institution in the state which existed only to provide teacher training. The Act completely altered the course of future educational development in Florida. Other states introduced coeducation at the time Florida ended it, and in other states normal schools continued to operate for another twenty to thirty years, before evolving into "state teacher's colleges." Had it not been for the Buckman Act, the normal school at DeFuniak almost certainly would have eventually become a teacher's college, and Florida would probably have had similar institutions in other parts of the state. The Act gave Florida two statesupported institutions, which remained gender-segregated until 1947. No other state-supported institutions of higher education opened for almost sixty years after the Buckman Act. Dade County, Florida's most populous county, did not have a state university for nearly seventy years after the legislature drastically altered 
the future course of Florida higher education.

Is it possible to determine what became of these students after college? If so, what was the impact of their education at the college on their future activities? Information gathered from an alumni report, the school's newspaper, and Biennial Reports indicated that a number of students stayed in education. Male graduates included administrators, superintendents, a professor, and a state superintendent of education. It is likely that most of the women married, changing their names, but the small amount of information obtained indicated that a good number of them taught, and a few even became principals, which was a rarity in those days. Jurgen Herbst contended that the normal schools failed to train teachers, but served as institutions of higher education which gave young men a chance to enter other professions. The alumni survey does indicate that a number of the young men entered other professions. Still, with the limited information available, it is not possible to determine whether Herbst was correct in his assertion. Numbers of students never graduated, but certainly continued to teach, and normal school students were among those earning the highest teacher certificates, attending educational conventions, and serving as officers in the state teacher's association. Many more students attended the college than graduated, 
but the system of certifying teachers in those days made it attractive to stay in school just long enough to qualify for a certificate. Such students still carried home the ideas and practices they had observed at the DeFuniak school. One hundred and twenty five students were able to complete a normal school education with the assistance of the county scholarships established in 1901. The normal school faculty taught many of the teacher institutes which Florida teachers attended. The normal school's kindergarten and model school programs were modern and influenced later educators.

How did the institution and its students reflect the dominant trends in American education? What can the study of the Florida state Normal College add to our understanding of gender roles, education, and progressivism in the New South? It was hoped that this dissertation would illuminate other themes in history and in education. The normal school mirrored national educational trends in curriculum, activities, and the professionalization of teaching. It also serves as a prism through which larger social trends can be viewed. The movement for education in the South, according to Ayers, was a movement which originated with southerners, not with northern philanthropists. Florida did not have a Southern Education Board "crusade" until after the normal school closed, yet Florida had a higher literacy 
rate than other southern states, and had established a common school system at the same time, or even earlier, as other southern states more involved with the Board's activities. This supports Ayers's observation.

According to Link and Grantham, a primary aim of progressive school reformers around the south was to eradicate southern individualism and socialize rural children to work and live in an industrialized economy. The curriculum of the normal school supports the idea that the state regarded the common schools as a way to force southern children and their families to "modernize."

The normal school also illustrated the alacrity with which students sought a higher education when it became available at a nearby location. In 1915, the General Education Board reported that colleges in the United States drew their students from the population living within two hundred miles of the institution. Only a small percentage of women students lived farther than a hundred miles from the colleges. The residents of Walton County strongly supported the school and quickly sent their children to study there. Much later in the twentieth century, the growth of the Florida community college system demonstrated, again, that geographical accessibility is a factor of primary importance in higher education. 
The school also adds to our knowledge of gender roles in Florida. Two gender-segregated institutions, the University of Florida and the Florida state college for Women dominated Florida education for so long that the fact that before 1905 Florida had coeducational institutions had been obscured. The students at the normal school in DeFuniak studied in a truly coeducational environment, and faculty minutes indicate that the students' behavior could not be faulted. A century ago, large numbers of young women in Florida worked, and their parents, if higher education was available, supported their daughters's educational goals.

The history of women's higher education has focused almost exclusively on young women attending prestigious northeastern women's colleges and large universities. The history of the Florida state Normal College adds a new dimension to our understanding of the development of the higher educational system of this country and, in particular, of this state. The normal school at DeFuniak Springs welcomed men and women who could not travel to far-off colleges, prepared them for a useful profession, and taught them in a coeducational environment with a minimum of parietal rules. The closing of the school illustrates the drastic effect one legislator can have on an entire state. It is remarkable that other alternatives to the system proposed by Buckman were not 
discussed and that the implications for the educational future of Florida were so little considered. After the 1905 legislature committed Florida's higher education to two institutions, the system remained unchanged for generations. We can only speculate on how many bright young women and men living in the southern part of the state never had an opportunity for a college education because Tallahassee or Gainesville were too far away for them to attend. If college is not affordable, or possible to get to, it is not accessible.

The research demonstrated the degree to which political maneuverings by politicians willing to use gender as a weapon affected generations of students in this state. The two new institutions established by the Buckman Act could have remained coeducational. Instead, the leaders of the Lake city institution used the backlash against women in American higher education to secure their own position as the state's flagship university. Of course, in 1905 women neither voted nor served in the legislature. Legislative favoritism for the University of Florida was notorious for decades. Only in recent years have important and necessary graduate and undergraduate programs become available in other state institutions.

Further research in several of the areas touched on by this study would be of great value in making the story 
of American education more complete. The normal schools educated huge numbers of students, and further research into into the normal college movement in the southern states would be very instructive. The effect on the number of degreed Floridians of a state system of higher education confined for so long to only two institutions would be a difficult but fascinating question to research, as would the effect of the long period of sex segregated university schooling. The actions of state legislatures with respect to educational systems are another valuable area of research. Publicly supported institutions must be under control of the public, but the passage of the Buckman Act illustrates the ways in which legislation can be passed almost by default. Any information which could be gleaned on the other small institutions of the times would help to complete the story of Florida and its schools during the New South. A study of the women faculty at different southern institutions would be fascinating. There are indications from this study that those who remained single may have moved around, teaching in different normal schools. What were their lives like?

Finally, the study illustrated that higher educational systems evolve as the result of conflicting hopes, needs, and pressures. Florida's system developed in response to a unique set of circumstances. Careful 
consideration of the development of higher educational systems in the United States confirms that there is no one best way to educate our people. Educational systems mirror life itself and evolve as the world we live in changes. A sense of the patience and optimism with which teachers a hundred years ago challenged appalling educational conditions can give modern educators a sense of perspective and hopefulness when attempting to solve our own challenges. Early educators believed, more than anything else, that ignorance could be vanquished with the light of learning. The teachers and students of the Florida state Normal College would have been pleased to be remembered for all of these things, and for their strivings to educate themselves and others, which were carried out with the highest ideals. 


\section{References}

Primary sources and contemporary materials

Adams, H. (1990 edition). The education of Henry Adams. New York: Vintage Books/The Library of America.

Are there too many women teachers? (1904). Educational Review, 28, 98-105.

Bardeen, C. W. (1908). Why teaching repels men. Educational Review, 35, 351-357.

Baseball program, DeFuniak Springs, 1900.

Beautiful De Funiak Springs, the celebrated Chautauqua and winter resort of Florida, with the compliments of the Hotel Chautauqua. Publicity brochure, c 1900 .

Biennial Reports of the Florida Superintendent of Public Instruction (1885-1913). Tallahassee.

Bush, G. G. (1889). History of education in Florida: Bureau of Education Circular of Information No. 7. Washington: Government Printing office.

Cawthon, M. A. (Jan. 15, 1883). Personal correspondence.

Cawthon, W. L. (Feb. 1, 1883). Personal correspondence.

Chadwick, F. E. (1914). The woman peril in education. Educational Review, 47, 109-119.

Coffman, L. D. (1911). The social composition of the teaching population. New York: Teachers College Contributions to Education.

Connor, R. W. D. (1905). The Peabody Education Fund. South Atlantic Quarterly, 4, 169-181.

Dabney, C. E. (1901). The public school problem in the South. Proceedings of the Fourth Conference for Education in the South. Harrisburg: Mount Pleasant Press. 
Daniels, J. (1907). The progress of southern education. The Annals of the American Academy. New York.

Dickerman, G. S. (1901). Agent's report. Proceedings of the Fourth Conference for Education in the South.

Harrisburg: Mount Pleasant Press.

Eliot, C. W. (1875). Wise and unwise economy in schools. New England Journal of Education, 22 (1), 220-222.

Erskine, Elma (1889). Autograph book.

Florida Agricultural College, Lake City, Florida. Catalogs, 1893, 1897.

Florida Normal School and Business College, White Springs, Florida. Catalog, 1891.

Florida State Normal College Alumni Association Program, 1897.

Florida State Normal College, Brochure, 1900.

Florida State Normal College, Catalogs for 1888, 1890, $1893,1898,1901,1902$, and 1904.

Florida State Normal College, Commencement Programs.

Florida State Normal College for White Students in DeFuniak Springs, Register and Minutes.

General Education Board (1915). The General Education Board: An account of its activities. New York: General Education Board.

Hart, A. B. (1910). The southern South. New York: Appleton and Company.

Henry, J. K. (1895). The new woman of the new South, Arena, 11, 353-362.

Heritage Association of De Funiak Springs, Annual Calendars (1992, 1993, 1994). De Funiak Springs.

Mayo, A. D. (1892). Southern women in the recent educational movement in the South: Bureau of Education Circular of Information No. 1. Washington: Government Printing office.

McKinnon, J. I. (1911). History of Walton County. Atlanta: Byrd Publishing Company. 
Page, D. P. (Branson, E. C., ed.). (1899). Theory and Practice of Teaching. New York: American Book Company.

Palmer College Catalog, 1912-1913.

Register of the Florida State Normal College for white Students at De Funiak Springs, Florida.

Executive Committee (1911). Registered members. Fourteenth Conference for Education in the South. Knoxville: Southern Education Board.

Russell, Mrs. A. J. (1897). Life and labors of Albert J. Russell: A collection of writings showing some of his efforts in behalf of his fellow-men. Jacksonville: Dacosta Printing Company.

Schindler, S. (1892). A flaw in our public school system. Arena, 6, 59-63.

Smart, J. H. (1885). Teacher's Institutes: Bureau of Education Circular of Information No. 2. Washington: Government Printing office.

State Normal Messenger, December 1898 and March 1899.

Stave, B. M. (Ed.). (1992). Fire insurance maps from the Sanborn Map Company archives, late 19th century to 1990: Florida. Bethesda: University Publications of America.

Tampa Morning Tribune.

Thach, C. C. (1902). Industrial education: The hope of the South. Proceedings of the Fifth Conference for Education in the South. Knoxville: Southern Education Board.

Turner, C. F. (1914). DeFuniak Springs and Walton County Florida. De Funiak Springs: City Council, County Commissioners, and Board of Trade.

United States Commissioner of Education, Annual Reports $(1888$ - 1906). Washington: Government Printing Office.

United States Government Printing office

Twelfth Census of the United States, Original Census Record for the state of Florida Twelfth Census of the United States Summaries and 
Statistics

Farm Tenancy in the United States, 1925

Characteristics of Teachers in the United States, 1905

Watson, A. R. (1895). The attitude of southern women on the suffrage question. Arena, 11, 363-369.

Week1y Critic, DeFuniak Springs, Oct. 24, 1888.

White, E. A. (1894). School management: A practical treatise for teachers and all other persons interested in the right training of the young. New York: American Book Company. 


\section{Secondary references}

Adams, A. H. (1962). A History of Public Higher Education in Florida: 1821-1961. Doctoral dissertation, Florida State University, Tallahassee.

Allmendinger, D. F. (1979). Mount Holyoke students encounter the need for life-planning, 1837-1850. History of Education Quarterly, 19 (1), 27-47.

Antler, J. (1977). The educated woman and professionalization: The struggle for a new feminine identity, 1890-1920. Doctoral dissertation, State University of New York, Stony Brook.

Avent, J. E. (1925). The summer sessions in state teacher's college as a factor in the professional education of teachers. Washington: National Council of Education.

Ayers, E. L. (1992). The promise of the new south: Life after reconstruction. New York: Oxford University Press.

Berkeley, K. C. (1984). The ladies want to bring about reform in the public schools: Public education and women's rights in the post-Civil war South. History of Education Quarterly, 24 (1), 45-58.

Bernhard, V., Brandon, B., Fox-Genovese, E., Perdue, T., \& Turner, E. H. (Eds.). (1994). Hidden histories of women in the New South. Columbia: University of Missouri Press.

Blazek, R. (1987). The library, the chautauqua, and the railroads in De Funiak Springs, Florida. Journal of Library History, 22 (4), 377-396.

Boas, L. S. (1935). Women's education begins: The rise of women's colleges. Norton, Mass.: Wheaton College Press.

Bristol, L. M. (1944). The Buckman ACt: Before and after (A study in historical sociology).

(Monograph). Gainesville: The University of Florida. 
Bristol, L. M. (1952). Three focal points in the development of Florida's state system of higher education. Lectures at the College of Education. Gainesville: The University of Florida.

Brubacher, J. S. \& Rudy, W. (3rd ed., 1976). Higher education in transition: A history of American colleges and universities, 1636-1976. New York, Harper \& Row.

Brumberg, J. J. (1983). The feminization of teaching: Romantic sexism and American Protestant denominationalism. History of Education Quarterly $23,379-385$.

Bunkle, P. (1974). Sentimental womanhood and domestic education, 1830-1970. History of Education Quarterly, 14 (1), 13-29.

City of De Funiak Springs (1993). Community Information Guide.

Clifford, G. J. (1978). Home and school in 19 th century America: Some personal-history reports from the United States. History of Education Quarterly, 18 (1), 3-32.

Clifford, G. J. (1979). Distortion in the historiography of American education: The problem of silence. Paper presented at the annual meeting of the American Educational Research Association, San Francisco. (ERIC Document Reproduction Service No. ED 168 195).

Clifford, G. J. (1982). "Marry, stitch, die, or do worse": Educating women for work. In Kantor, H. \& Tyack, D. B. (Eds.), Work, youth and schooling: Historical perspectives on vocationalism in American education. Stanford: Stanford University Press.

Clifford, G. J. (1983). "Shaking dangerous questions from the crease": Gender and American higher education. Feminist Issues 3, 31-62.

Clifford, G. J. (1988). Women's liberation and women's professions: Reconsidering the past, present, and future. In Faragher, J. M. \& Howe, F. (Eds.), Women and higher education in American history: Essays from the Mount Holyoke sesquicentennial symposia. New York: W. W. Norton. 
Clifford, G. J. (1989). Man/woman/teacher: Gender, family, and career in American educational history. In Warren, D. (Ed.), American teachers: Histories of a profession at work. New York: Macmillan.

Coburn, C. K. (1988). The case against coeducation: An historical perspective. Feminist Teacher, 3 (3), 19-22.

Cochran, T. E. (1921). History of public-school education in Florida. Tallahassee: State Department of Education.

Conway, J. K. (1974). Perspectives on the history of women's education in the United States. History of Education Quarterly, 14 (1), 1-12.

Conway, J. K. (1985). The female experience in eighteenth and nineteenth century America: A guide to the history of American women. Princeton: Princeton University Press.

Cordier, M. H. (1992). Schoolwomen of the prairies and plains: Personal narratives from Iowa, Kansas, and Nebraska, 1860s - 1920s. Albuquerque: University of New Mexico Press.

Cremin, L. A. (1988). American education: The metropolitan experience 1876-1980. New York: Harper \& Row.

Crow, C. L. The Buckman Act. (Monograph). Gainesville: The University of Florida.

Cutler, H. G. (1923). History of Florida past and present: Historical and biographical, Vol. I. Chicago: Lewis Publishing Company.

Dabney, C. W. (1936/1969). Universal education in the south: Volumes $I$ and II. Chapel Hill: The University of North Carolina Press.

DeBolt, D. (1990). The Florida Chautauqua. FEH: The magazine of the Florida Endowment for the Humanities, 13 (3), 6-10.

Dietrich, T. S. (1978). The urbanization of Florida's population: An historical perspective of county growth 1830-1870. Gainesville: University of Florida. 
Dodd, W. G. (1952). West Florida Seminary, 1857-1901; Florida State College 1901-1905. Tallahassee: Florida state University.

Durbin, N. E. \& Kent, L. (1989). Postsecondary education of white women in 1900. Sociology of Education, 62, $1-13$.

Dyer, T. G. (1985). Higher education in the South since the Civil War: Historiographical issues and trends. In Fraser, W. J., Jr., Saunders, R. F., Jr. , \& Wakelyn, J. L. (Eds.), The web of southern social relations: Women, family, and education. Athens: The University of Georgia Press.

Elsbree, W. S. (1939/1970). The American teacher: Evolution of a profession in a democracy. Westport: Greenwood Press.

Evans, S. M. (1989). Born for liberty: A history of women in America. New York: Free Press.

Farnham, C. A. (1994). The education of the southern belle: Higher education and student socialization in the antebellum South. New York: New York University Press.

Fischer, D. H. (1989). Albion's seed: Four British folkways in America. New York: Oxford University Press.

Florida Education Association (1958). History of the Florida Education Association 1886-7 to 1956-7. Tallahassee: Florida Education Association.

Fox-Genovese, E. (1994). Afterword. In Bernhard, V., Brandon, B. Fox-Genovese, E., Perdue, T. \& Turner, E. H. (Eds.), (1994). Hidden histories of women in the New South. Columbia: University of Missouri Press.

Frankfort, R. (1977). Collegiate women: Domesticity and career in turn-of-the-century America. New York: New York University Press.

Friedlander, A. (1981). A more perfect Christian womanhood: Higher learning for a New South. In Goodenow, R. K. \& White, A. O. (Eds.), Education and the rise of the New South. Boston: G. K. Hall. 
Friedman, J. (1985). The enclosed garden: Women and community in the evangelical South, 1830-1900. Chapel Hill: The University of North Carolina Press.

Gannon, M. (1993). Florida: A short history. Gainesville: University Press of Florida.

Gershenberg, I. Southern values and public education: A revision. History of Education Quarterly 10 , 413-422.

Gordon, L. D. (1979). Co-education on two campuses: Berkeley and Chicago, 1890-19121. In Kelley, $M$. (Ed.), Woman's being, woman's place: Female identity and vocation in American history. Boston: G. K. Hall.

Goulding, R. L. (1933). The development of teacher training in Florida. Doctoral dissertation, George Peabody College for Teachers, Nashville.

Graham, P. A. (1978). Expansion and exclusion: A history of women in American higher education. Signs: Journal of Women in Culture and Society, 3 (4), 759-773.

Grantham, D. W. (1983). Southern progressivism: The reconciliation of progress and tradition.

Knoxville: The University of Tennessee Press.

Hammond, S. L. (1954). Historical development of schools for young children in Florida. In Mamatey, $V$. (Ed.), Education in Florida past and present. Tallahassee: Florida State University.

Hammond, S. L. (1959). Anna E. Chaires and kindergarten education in Florida. Preu, J. (Ed.). Florida Educators. Tallahassee: Florida State University.

Harlan, L. R. (1957). The Southern Education Board and the race issue in public education. Journal of Southern History, 23 (2), 189-202.

Harper, C. A. (1939). A century of public teacher education: The story of the state teacher's colleges as they evolved from the normal schools. Washington: The National Education Association. 
Herbst, J. (1989). Teacher preparation in the nineteenth century: Institutions and purposes. In Warren, D. (Ed.), American teachers: Histories of a profession at work. New York: Macmillan.

Hoffman, N. (Ed.). (1981). Woman's "true" profession: Voices from the history of teaching. New York: McGraw Hill.

Horowitz, H. L. (1987). Campus life: Undergraduate cultures from the end of the eighteenth century to the present. Chicago: The University of Chicago Press.

Jenkins, W. D. (1979). Housewifery and motherhood: The question of role change in the Progressive Era. In Kelley, M. (Ed.), Woman's being, woman's place: Female identity and vocation in American history. Boston: G. K. Hall.

Jones, J. P. (1985). North Florida's Lotus Land. North Florida Living, 5 (7), 6-13.

Judd, C. D. (1921). The summer school as an agency for the training of teachers in the United States. Nashville: George Peabody College for Teachers.

Kaufman, P. (1984). Women teachers on the frontier. New Haven: Yale University Press.

Kelley, M. (Ed.). (1979). Woman's being, woman's place: Female identity and vocation in American history. Boston: G. K. Hall \& Company.

Kett, J. (1985). Women and the progressive impulse in southern education. In Fraser, W. J., Jr., Saunders, R. F., Jr., \& Wakelyn, J. L. (Eds.), The web of southern social relations: Women, family, and education. Athens: The University of Georgia Press.

Kousser, J. M. (1980). Progressivism - for middle-class whites only: North Carolina education, 1880-1910. Journal of Southern History, 46 (2), 169-194.

Link, W. A. (1986). A hard country and a lonely place: Schooling, society, and reform in rural Virginia, 1870 - 1920. Chapel Hill: The University of North Carolina Press. 
Link, W. A. (1992). The paradox of southern progressivism, 1880 - 1930. Chapel Hill: The University of North Carolina Press.

Lucas, C. J. (1994). American higher education: A history. New York: St. Martin's Press.

Mamatey, V. (Ed.). (1954). Education in Florida past and present. Florida State University Studies Number Fifteen. Tallahassee: The Florida State University.

Marsden, (1994). The soul of the American university: From Protestant establishment to established nonbelief. New York: Oxford University Press.

McGovern, J. R. (1961). The American woman's pre-World War I freedom in manners and morals. Journal of American History, 55 (2), 315-333.

Newcomer, M. (1959). A century of higher education for women. New York: Harper \& Brothers Publishers.

Ogren, C. A. (1995). When coeds were coeducational: Normal schools in Wisconsin, 1870-1920. History of Education Quarterly, 35 (1), 1-26.

Orr, M. L. (1930). The state-supported colleges for women. Nashville: George Peabody College for Teachers.

Palmieri, P. A. (1983). Here was fellowship: A social portrait of academic women at Wellesley College, 1895 - 1920. History of Education Quarterly, 23 (2), 195-213.

Parker, O. L. (1949). William N. Sheats, Florida educator. Master's thesis, Gainesville, The University of Florida.

Perry, L. (1984). Intellectual life in America: A history. New York: Franklin Watts.

Preu, J. (Ed.). (1949). Florida educators. Florida State University Studies Number 30. Tallahasse: The Florida State University.

Proctor, S. (1958). The first fifty years: The University of Florida 1853 to 1903. Doctoral dissertation, Gainesville, The University of Florida. 
Proctor, S. (1996). Prelude to the New Florida, 18771919. Gannon, M. (Ed.) (1996). The new history of Florida. Gainesville: University Press of Florida, 266-286.

Pyburn, N. K. (1954). The history of the development of a single system of education in Florida 1822-1903. Tallahassee: Florida State University.

Pyburn, N. K. The Florida Chautauqua. (Monograph). Tallahasse: Florida State University.

Richardson, J. G. \& Hatcher, B. W. (1983). The feminization of public school teaching 1870-1920. Work and Occupations, 10 (1), 81-99.

Rosen, F. B. (1977). The influence of the Peabody Fund on education in Reconstruction Florida. Florida Historical Quarterly 55 (3), 310-320.

Rosenberg, R. (1982). Beyond separate spheres: Intellectual roots of modern feminism. New Haven: Yale University Press.

Rosenberg, R. (1992). Divided lives: American women in the twentieth century. New York: Hill and Wang.

Rothman, S. (1978). Woman's proper place: A history of changing ideals and practices, 1870 to the present. New York: Basic Books.

Rudolph, F. (1962/1990). The American college and university: A history. Athens: The University of Georgia Press.

Rury, J. L. (1989). Who became teachers? The social characteristics of teachers in American history. In Warren, D. (Ed.), American teachers: Histories of a profession at work. New York: Macmillan.

Rury, J. L. (1991). Education and women's work: Female schooling and the division of labor in urban

America, 1870 - 1930. Albany: State University of New York Press.

Sellers, R. J. (1995). Femina perfecta: The genesis of Florida State University. Tallahassee: The Florida State University Foundation.

Servies, J.A. (1982). A bibliography of West Florida, 3rd edition. Pensacola. 
Schwager, S. (1987). Educating women in America. Signs: Journal of Women in Culture and Society 12 (2), 333372 .

Scott, A. F. (1970). The southern lady from pedestal to politics, 1830-1930. Chicago: The University of Chicago Press.

Scott, A. F. (1979). The ever widening circle: The diffusion of feminist values from the Troy Female Seminary 1822-1872. History of Education Quarterly 19 (1), 3-25.

Scott, A. F. (1984). Making the invisible woman visible. Chicago: The University of Illinois Press.

Solomon, B. M. (1985). In the company of educated women: A history of women and higher education in America. New Haven: Yale University Press.

Smith-Rosenberg, C. (1975). The female world of love and ritual: Relations between women in nineteenth century America. Signs: Journal of Women in culture and Society, 1 (1), 1-29.

Stakenas, R. G., Mock, D. B. \& Eaddy, K. M. (1984). Educating hand and mind: A history of vocational education in Florida. New York: University Press of America.

Steedman, C. (1985). 'The mother made conscious': The historical development of a primary school pedagogy. History Workshop, 20, 149-163.

Tebeau, C. W. (1971). A history of Florida. Coral Gables: University of Miami Press.

Thomas, M. M. (1995). Alabama women during the Progressive Era. In Thomas, M. M. (Ed.), stepping out of the shadows: Alabama women. 1819-1990. Tuscaloosa: The University of Alabama Press.

Verner, C. (1954). A preliminary history of adult education in Florida. In Mamatey, V. (Ed.), Education in Florida past and present. Tallahassee: Florida state University.

Wein, R. (1974). Women's colleges and domesticity, 18751918. History of Education Quarterly 14 (1), 31-47. 
Wheeler, M. S. (1993). New Women of the New South: The Leaders of the Woman Suffrage Movement in the Southern States. New York: Oxford University Press.

White, A. O. (1979). One hundred years of state leadership in Florida public education.

Tallahassee: University Presses of Florida.

Woodward, C. V. (1951/1971). Origins of the New South 1877 - 1913. Baton Rouge: Louisiana State University Press.

Woodward, C. V. (1960/1968). The burden of southern history. Baton Rouge: Louisiana State University Press.

Woody, T. (1929/1974). A history of women's education in the United States. New York: Octagon Books.

Zimmerman, J. G. (1979). Daughters of Main street: Culture and the female community at Grinnel, 18841917. In Kelley, M. (Ed.), Woman's being, woman's place: Female identity and vocation in American history. Boston: G. K. Hall. 
Appendix A

$$
\begin{gathered}
\text { STATE NORMAL SCHOOL } \\
1903
\end{gathered}
$$

GRADUATES OF STATE NORMAL SCHOOL

(All graduates have L. I. Degree)

\section{TWO YEARS ' COURSE \\ Class of 1889}

W. T. Bludworth, Lawyer......................

S. C. Cawthon (Deceased)

S. D. Cawthon (Recently Vice-Principal state

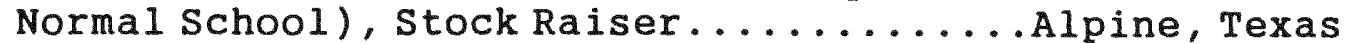
J. M. Calhoun, Lawyer.............................

J. M. Garrett, Mill Owner and Naval stores

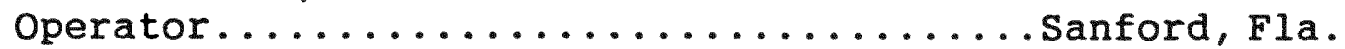
Jennie Dixon (Mrs. Crews) .................... T. W. Grace (Deceased)

Sallie Landrum (Mrs. S. D. Cawthon), Principal Practice School, state Normal School......... De Funiak Springs, Fla.

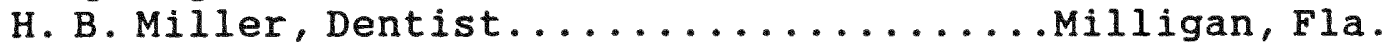

J. Reeves, Lawyer (Ex-Judge First Judicial

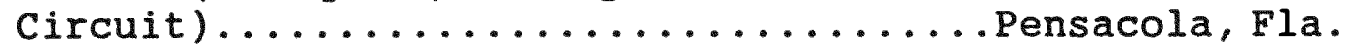
B. Speight (Deceased)

Class of 1890

Missouri Cawthon, Teacher of Music, Dalton Female College)...................Dalton, Ga. W. S. Cawthon, Professor Mathematics, State

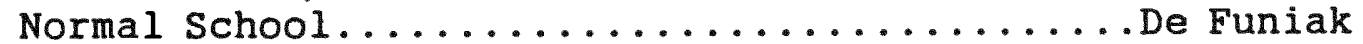
Springs

Libbie Dann (Deceased, taught several years)

Theo. Everett, Express Messenger.......Jacksonville, Fla. Stuart Knox Gillis, Lawyer............ Fe Funiak Springs W. L. Gordon, Farmer.................McDade's, Fla. Alonzo Hollowell, Assistant Post Master........ De Funiak Springs

Ida Jones (Mrs. N. C. McMillan).........Pensacola, Fla.

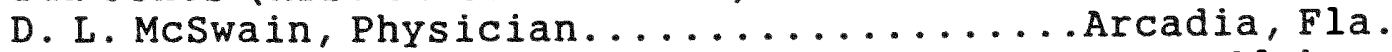

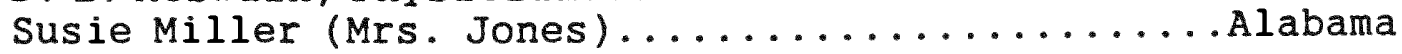

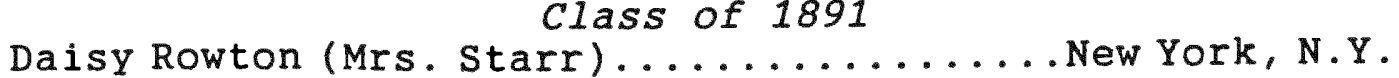

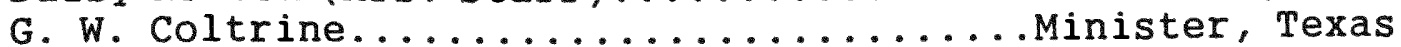
Sidney Cook (Deceased)

Carrie Campbell (Mrs. Dr. C. B. McKinnon)....Milton, Fla. Etta Hancock (Mrs. Cubberly), eleven years

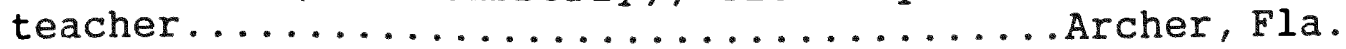


Victoria Hulse, Critic Teacher, New Orleans

Normal and Training Teacher........... New Orleans, La.

Class of 1892

Angus Graham Campbell, Lawyer................ Filton, Fla. M. B. Balcom (Deceased)

Mamie Baker (Mrs. F. Q. Tervin)............ De Funiak Springs

John W. Bowers, Assistant Cashier American

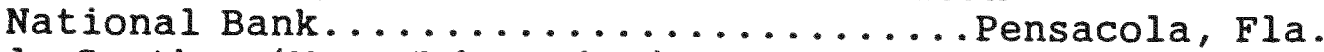
Ella Cawthon (Mrs. John Meigs)............ Florala, Ala. R. E L. Buie, Bookkeeper.............. Birmingham, Ala. W. F. King, Principal High School............ Bronson, Fla. Kate McKinnon (Mrs. A. G. Campbell)........Milton, Fla. M. A. Parish, Merchant and ex-member

Legislature...................Westville, Fla. John A. Jones, County Superintendent of

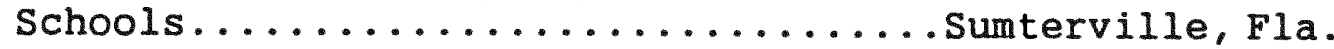

\section{THREE YEARS COURSE} Class of 1893

Christine 0. Gillis, Teacher........... Fe Funiak Springs

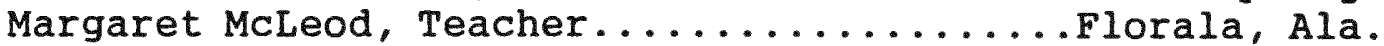

Class of 1894

Addie Beardsley, Teacher...............Florala, Ala. Coralie Gillis (Mrs. H. E. Wickersham).. De Funiak Springs Ida Parish (Mrs. Howell Jones)...............

\section{FOUR YEARS COURSE}

Class of 1896

Sallie Hemphill, Teacher....................... H. J. Rogers, Principal High School..... Brooksville, Fla. W. H. Watson, Lawyer and County Superintendent

of Schools.................... Fe Funiak springs

$$
\text { Class of } 1897
$$

Hurd Walker, Electrician....................... Finis Plank, Stock Raiser............ Fe Funiak Springs Joe B. Lockey, Principal High School......... DeLand, Fla. Hugh Brodie, Civil Engineer.

\section{Class of 1898}

Giles Bowers Campbel1, Lumber Dealer.... De Funiak Springs Retta McQuarrie, Stenographer...........Montgomery, Ala. Julia McKinnon, Stenographer to Principal state Normal

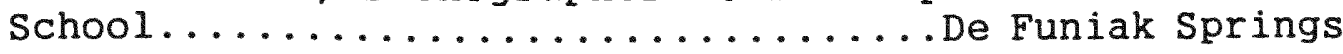

$$
\text { Class of } 1899
$$

Emma Campbell.................... Fe Funiak Springs

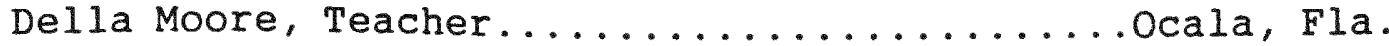


Christian McDonald, Teacher.............Freeport, Fla.

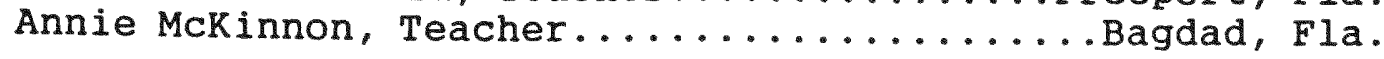

\section{Class of 1900}

Alameda Carter, Teacher................................ John M. Morrison (Deceased)

James MCL. Gillis, Bookkeeper............Pensacola, Fla. Annie Colvin, Stenographer..............

\section{Class of 1901}

Charles 0 . Andrews, Teacher..................... Orin A. Bailey, Custom House Official.....Pensacola, Fla. Kate Fitzgerald (Mrs. Thrower Sheppard).. Montgomery, Ala. W. B. Jernigan, Teacher....................... Clarence E. MCKinnon, Medical Student..... DesMoines, Iowa Edwin Wallace McMullen (A. B. Peabody Normal College),

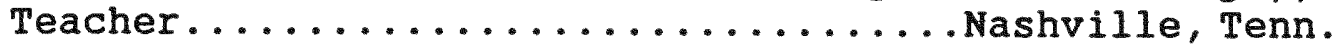

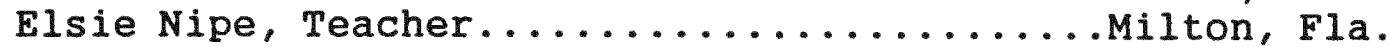

\section{Class of 1902}

John David Gable, Principal High School......Eustis, Fla. Lorenzo Dow Hathaway, Tax Collector........Westville, Fla. John Curtis McKinnon, Stenographer..... Jacksonville, Fla. LeRoy D. McRae, Principal High School.......Marianna, Fla.

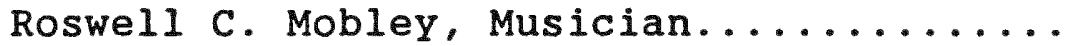

Don Register (Student Peabody Normal College)

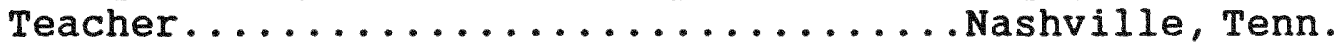
George A. Stephens, Principal High

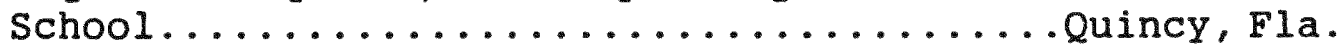
Edward P. Watson, Teacher....................

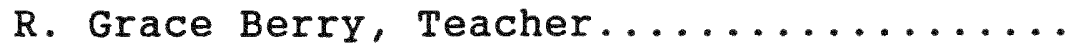

Rylla Bailey, Teacher.................. Columbia City, Fla. Fannie Lou Cawthon, Teacher........... De Funiak Springs 
Oct. 8, 1950

1972

1972-1973

1975

1975

1976-1985

1986-1989

$1990-1993$

1992-Present

1993-1994
Born, Nashville, Tennessee

B. A., History

Florida Atlantic University

Boca Raton, Florida

First grade teacher American School of Guatemala Guatemala City, Guatemala

M. A., History

Florida Atlantic University

Boca Raton, Florida

Editor/Writer

Interamerican Institute of Agricultural Sciences

Guatemala City, Guatemala

Assistant Controller

Sonesta Beach Hotel

Key Biscayne, Florida

Director of Media Relations Feinschreiber and Associates

Key Biscayne, Florida

Substitute teacher

Dade County, Florida

Adjunct professor of Social Sciences Miami-Dade Community College

Miami, Florida

Adjunct professor of History

Barry University

Miami, Florida 